\title{
عادات الموت كمحدد للسمات الثقافية \\ للمجتمعات الريفية فى المجتمع المصرى
}

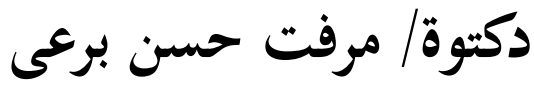 \\ المدرس بقسم الاجتماع - كلية الآداب والعلوم الغنسانية

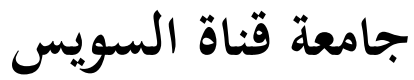


تعد العادات الشعبية ظاهرة أساسية من ظواهر الحياة الاجتماعية الإنسانية؛ وحقيقة أصيلة من حقائق الوجود الاجتماعى. نصادفها فى كل مجتمع، وعند الشعوب البدائية والمتقدمة وفى حالنى الاستقرار والانتقال، والاضطراب والتحول. وهى تتؤدى الكثير من

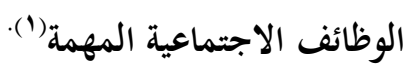
وإذا استعرضنا الدراسات التى تناولت الجوانب المختلفة للعادات الشعبية؛ والتى

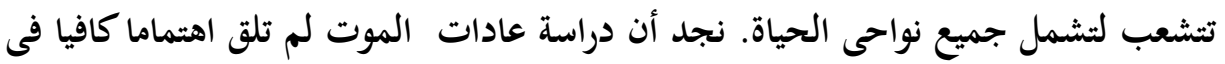
تلك الدراسات؛ على الرغم من أن الموت يحتل منزلة خاصة فى حياة المصريين، من حيث لهي اعتقادهم بأنه انتقال من حياة أولى فانية إلى حياة أخرى باقية. ولعل هذه السمة تتضح من خحلال ما أولاه المصريون القدماء من اهتمام بالموتى بالى بالى

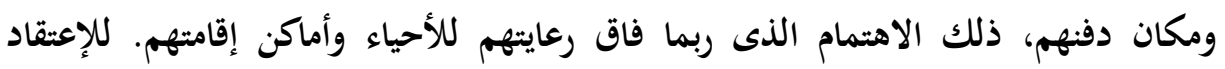
السائد عن الخلود فى حياة أبدية سرمدية.

وتعد الحقيقة الجوهرية المتعلقة بعادات الموت مجالا خصبا للدراسات الأنثربولوجية، ذلك لأن الموت وطقوسه يعكسان القيم الاجتماعية التى يرتبط بها الناس فى حياتهم،

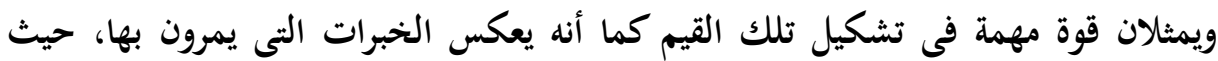
تتضح الأحوال الاجتماعية والثقافية الأساسية للبشر عند تناول تلك الطقوس (؟).

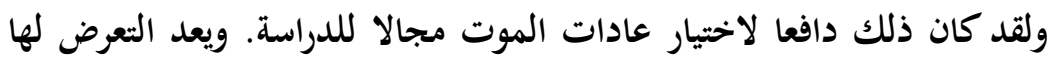
إسهاما متواضعًا في ميدان البحوث الفولكلورية التي تتناول جانبًا من جوانب دورة الحياة. أولا-أهمية دراسة الموضوع:

ترجع أهمية الدراسة وتتبلور في ضوء التغيرات التي يتعرض لها مجتمعنا، حيث

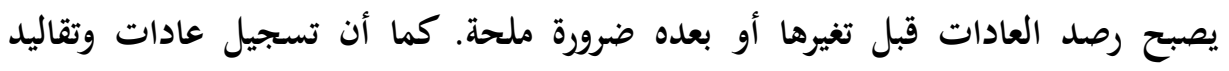
وطقوس الموت فى مجتمع من المجتمعات التقليدية يعطى أبعادًا أوفر لبحث تجانسها الثقافى، وفهم السمات الثقافية التى تميز مجتمعاتنا التقليدية ممايعمق فهمنا لأبعاد ثقافتنا ؛ لهنى حيث يشير بعضها لطبيعة الشخصية المصرية، ويسمح لنا بفهم العناصر الإيجابية فهما متعمقا للتغلب على القوى التى تحيط بنا، وزيادة قدرتنا على رؤية واقعنا الحضارى رؤية 
تسمح لنا بالتحكم فيه وتوجيهه لما في صالحنا، ونكون قد حاولنا أن نضع حجر الزاوية لأية محاولة تستهدف تطوير أو تغيير الواقع .

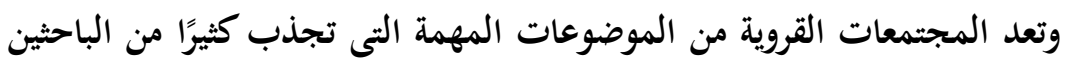

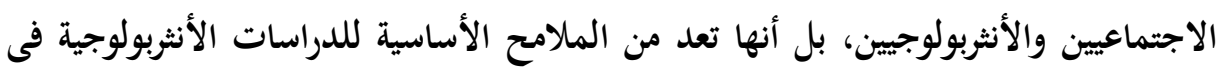

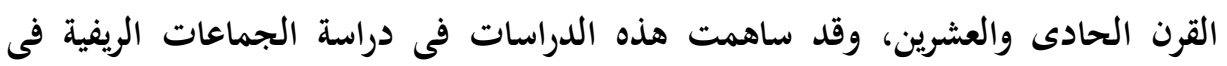

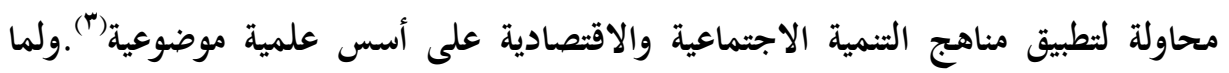

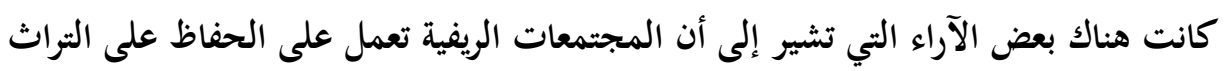

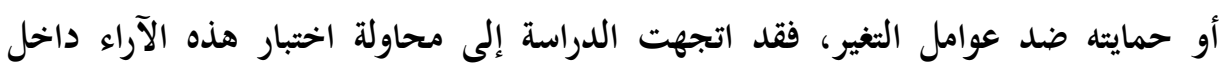

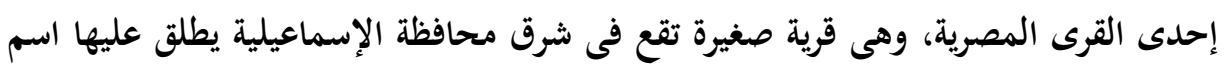

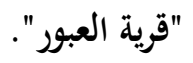

وتتضح أهمية تحديد السمات الثقافية من خلال دراسة عادات وتقاليد الموت

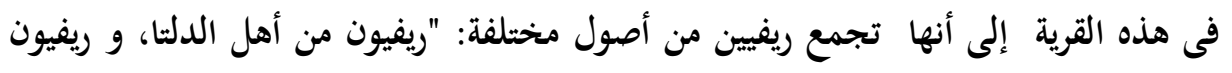

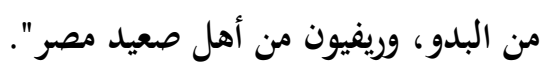

كما استهدفت الدراسة مقارنة ما تم جمعه من مادة اثنوجرافية حول عادات الموت،

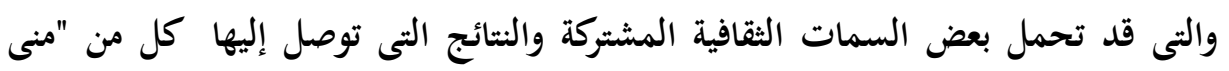

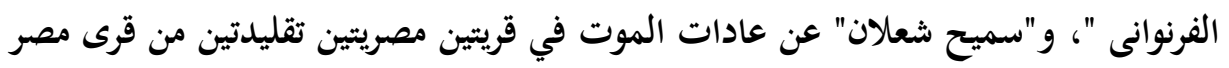

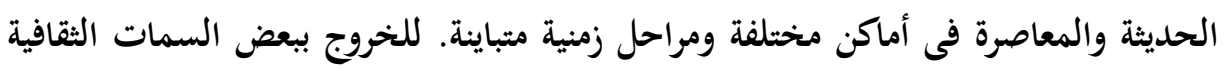

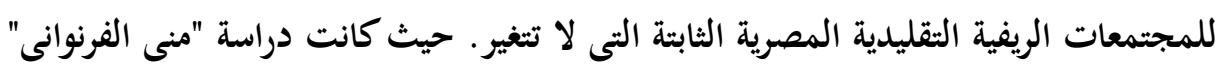

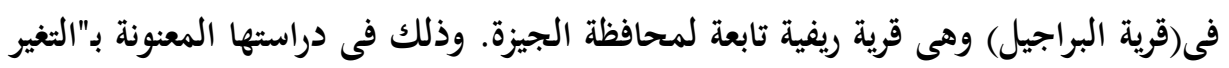

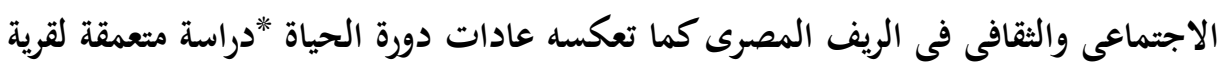

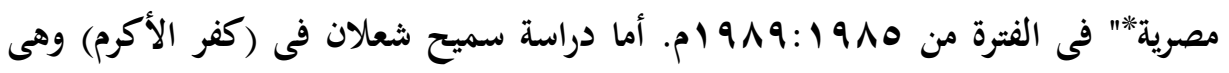

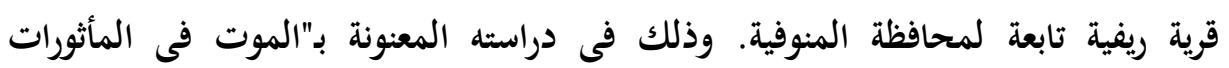

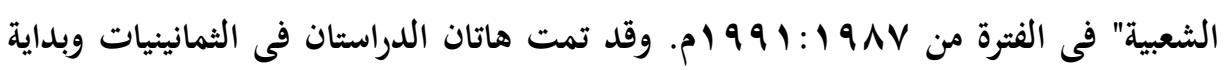
التسعينيات من هذا القرن على هذه المجتمعات التقليدية فى المجتمع المصرى. 
ويمكن من خلال دراستنا الكشف عن الخصائص المشتركة والملامح المتشابهة

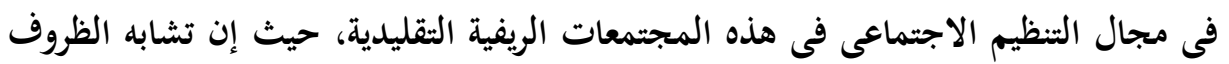

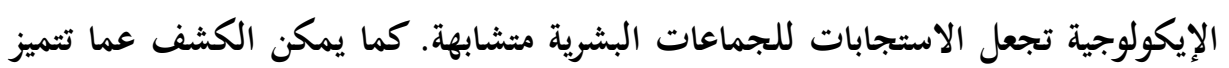

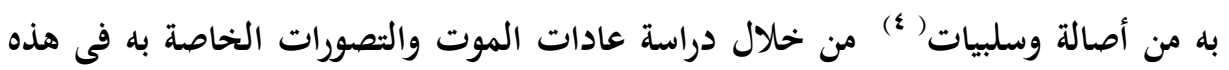

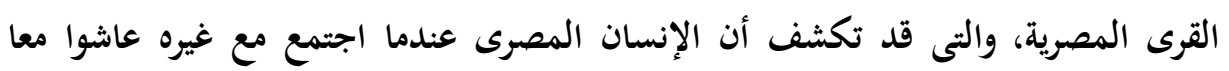

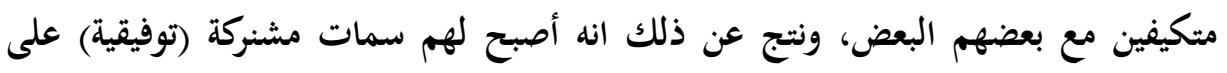

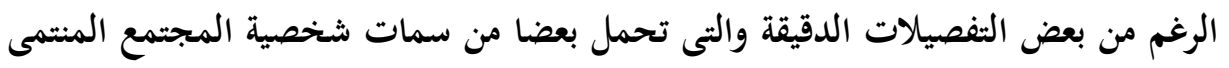

ونظرا لما يمثله الموت من مكانة خاصة فى حياة المصريين من حيث اعتقادهم

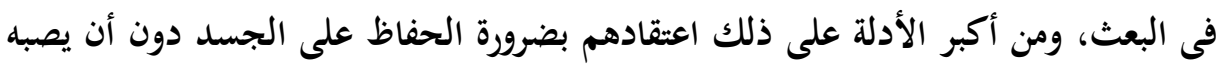

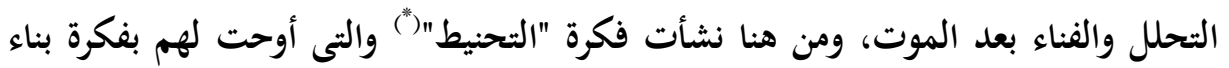

$$
\text { الأهرامات(•) }
$$

وهذا يدلنا على أن هناك سمة أساسية متأصلة في الشخصية المصرية ألا وهى

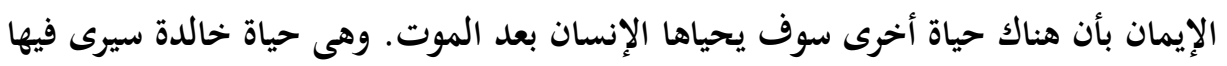

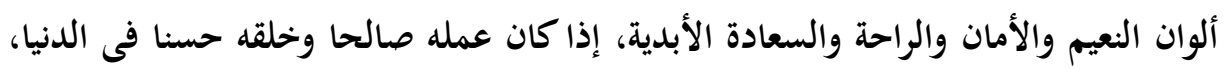

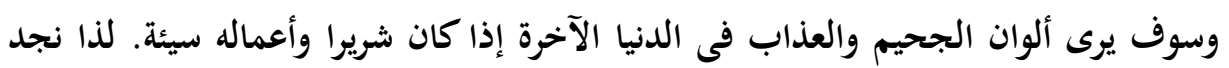
أن المصرى القديم عرف عنه حسن الخلق وخشية الله سبحانه وتعالى وعمل حساب الآخرة،

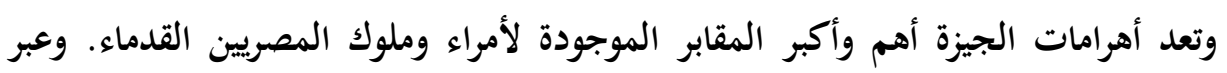

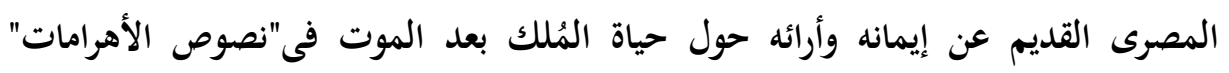

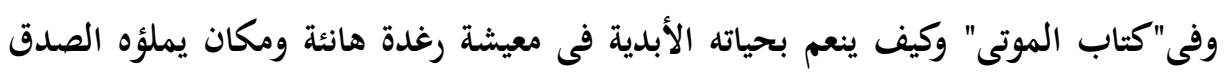
والمودة، إذا كان يقيم العدل فى حياته ويبعد عن جرائم الزنا والقتل والأخطاء المرتبطة ولئل بالزراعة وحقوق الأرض والماء ودفع الضرائب(آ)؟.

ودراسة عادات الموت بهدف محاولة رصد جوانب الموضوع داخل منطقة محددة.

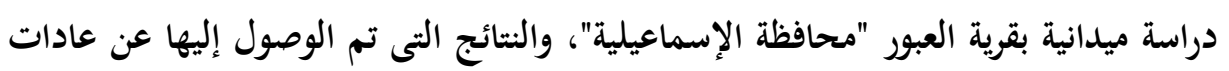

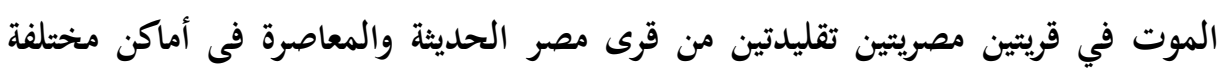


ومراحل زمنية متباينة. مما قد يؤدى للوصول إلى بيانات أكثر عمقا وتركيزا عن طبيعة البنية الثقافية للمجتمعات الريفية التقليدية، ومن ثم تحديد سماتها الثقافية.

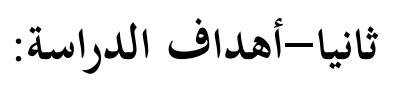

1- جمع وتسجيل لعادات وتقاليد الموت لمنطقة ثقافية قبل تغييرها أو اندثارها.

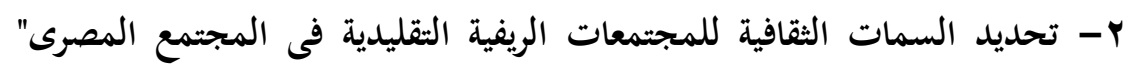

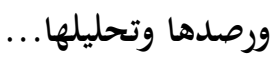

ب- تعميق فهمنا لأبعاد ثقافتنا وموروثاتنا الثقافية لزيادة قدرتنا على رؤية واقعنا الحضارى ومحاولة تغييره لما فيه صالح مجتمعنا المصرى وتطوره. ع - التعرف على المتغيرات الاجتماعية والاقتصادية المؤثرة فى عادات الموت والتى أدت إلى تغيرها.

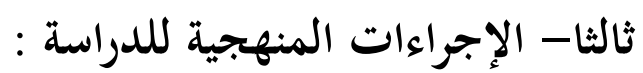

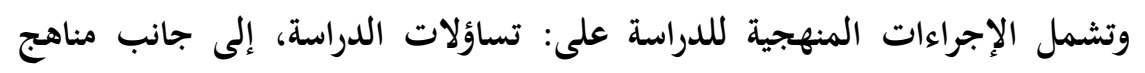

$$
\text { البحث وطرق جمع البيانات، وأخيراً فترة العمل الميداني . }
$$

وحيث إن هذه الدراسة تقوم على البحث الميدانى، فقد تم وضع مجموعة من

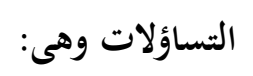

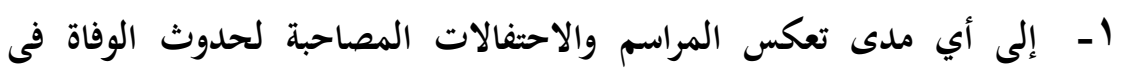

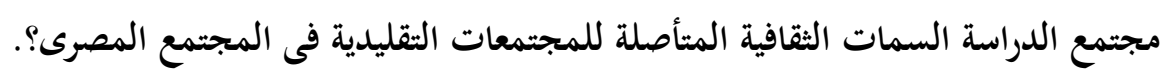
r- إلى أى مدى يتضح أثر الدين الإسلامي فى ثبات أو استمرار العادات والممارسات الشعبية التي تتعلق بالموت ؟. r- ما تأثير انتشار التعليم والوعى الدينى في استمرارية السمات الثقافية أوتغيرها

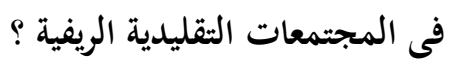

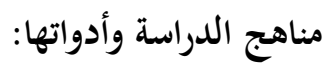

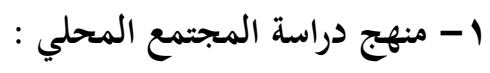


كان لمنهج دراسة المجتمع المحلي الدور الواضح في تناول الدراسة بوصفها تعبيراً

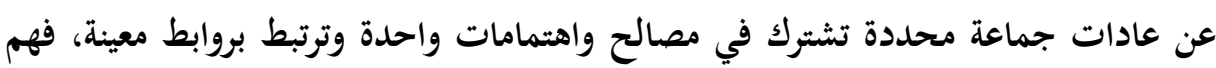

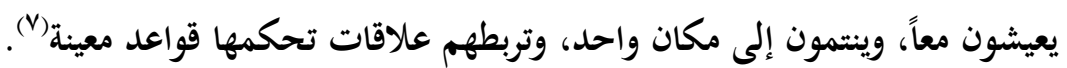
وقد وضع فى الاعتبار الدور الذى تلعبه المؤسسات الرسمية وغير الرسمية فى عادات

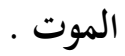

كما أسهم هذا المنهج فى التعرف على حدود المشاركة بين أفراد مجتمع البحث والتى تدعو إلى تفاعل الأفراد داخل المجتمع المحلى من أجل إلى الثباع حاجاتهم فى التواصل

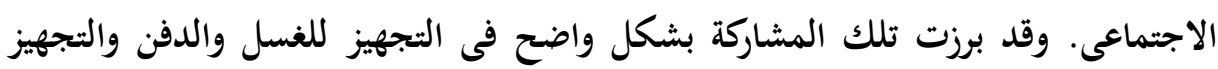

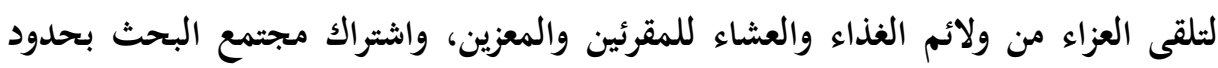

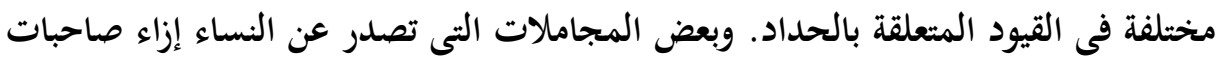

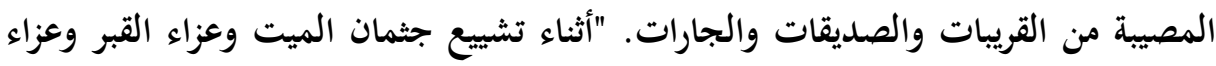

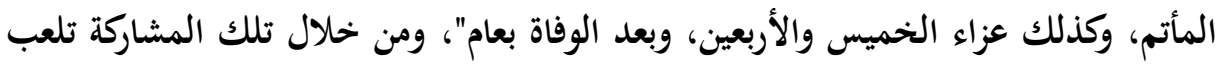

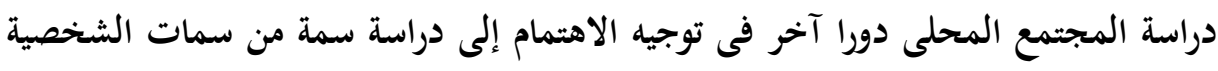

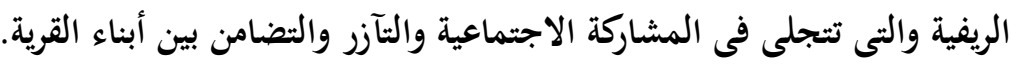

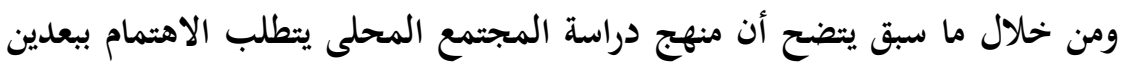

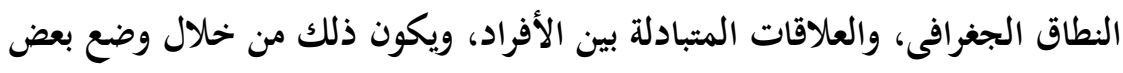
النقاط موضع الاعتبار، وتتمثل هذه النقاط فى :

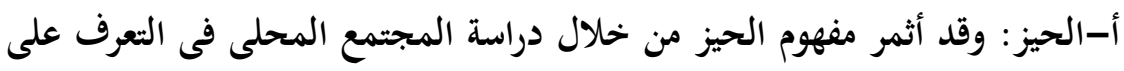

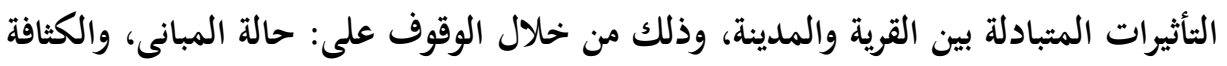

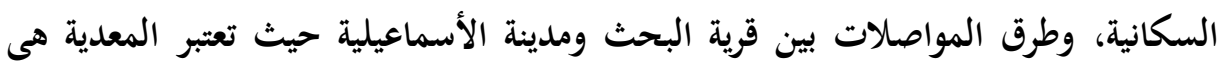

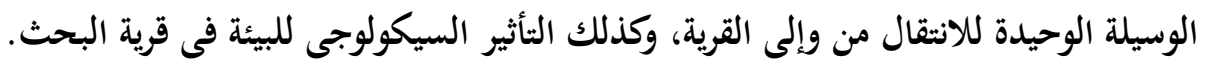

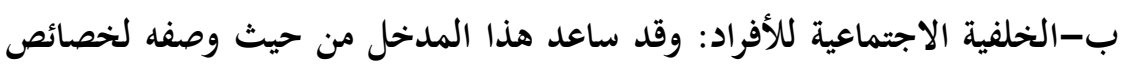
السكان الاجتماعية فى منطقة البحث فى التعرف على اختلاف العادات المتعلقة بالموت

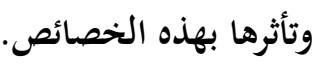


ج- الأنماط الثقافية: وقد أسهم هذا المنظور فى التعرف على وجود رموز متمثلة فى أنماط خاصة من السلوك والعادات والتى تميز أهل القرية عن غيرهم من القرى الأخرى، وتضفى عليهم نوعًا من الخصوصية.

د-التفاعل الفردى والجماعى: ويظهر هذا الثفاعل بصورة واضحة فى المشاركة

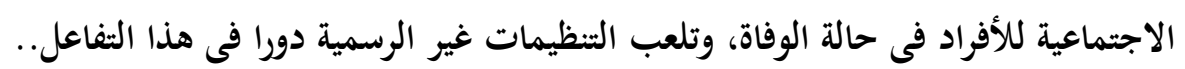

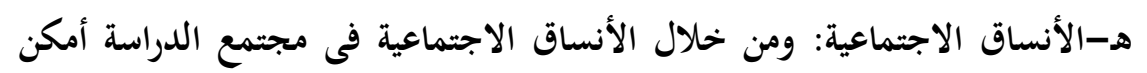

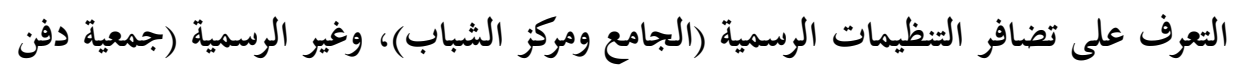

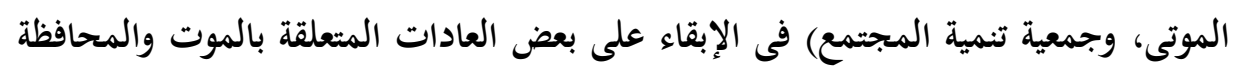

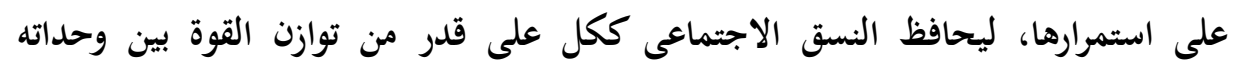
المختلفة..

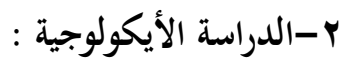

وقد استعان البحث بالدراسة الأيكولوجية بوصفها (تهتم بالخصائص الفيزيقية لبيئة

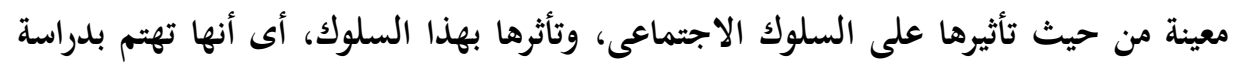

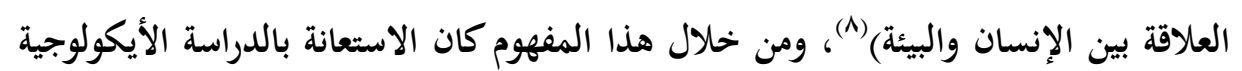

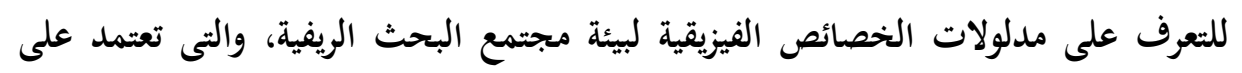
الإنتاج الزراعى بصفة أساسية. وقد كان لتلك الخصائص الأثر البالغ فى طبع عادات الموت بسمة خاصة تميزها عن غيرها من المجتمعات غير الريفية، حيث يستدعى العمل بالزراعة، المشاركة المتبادلة

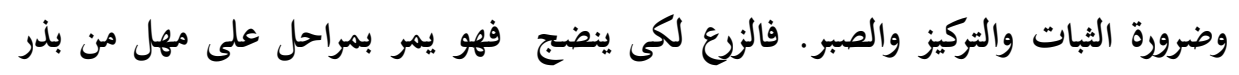
وسقى وانتظار الثمر والثبات أمام التقلبات الجوية. وكذلك المشاركة المتبادلة بين أفراد المجتمع والعمل المتواصل والتعاون فى إنجاز

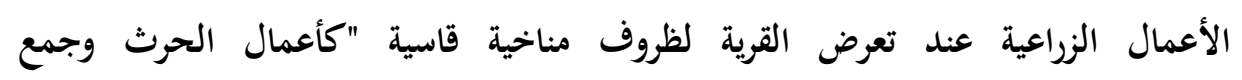

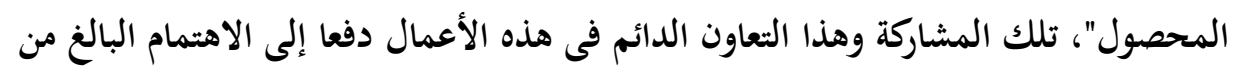

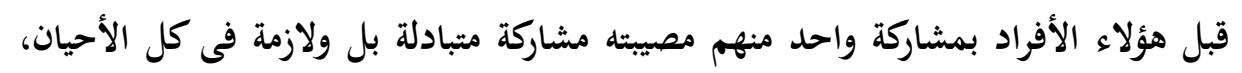
حيث يلقى المقصر لوما شديدا من قبل جماعته. 
إن النبات يتسم بالتجدد والنمو دائما تقطعه فينمو من جديد، وكأنه غفر الإساءة،

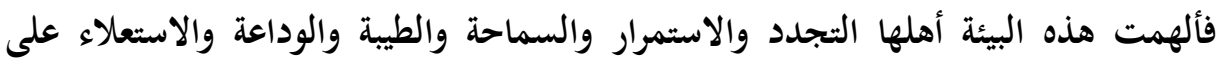

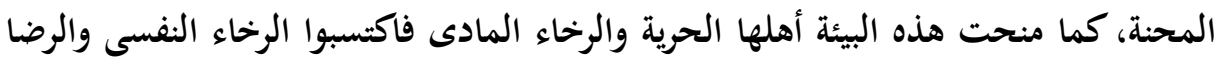

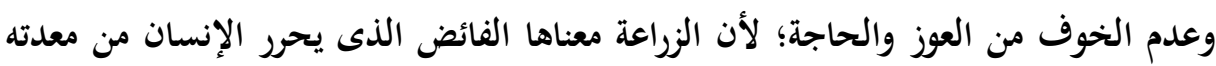

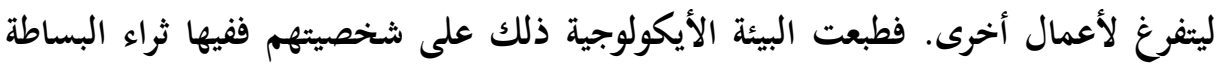
وزهد الغنى وجلال التواضع من حلول العهد بالوفرة والكثرة، وسكينة من مسالمة وسلام.

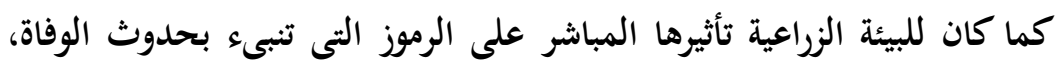

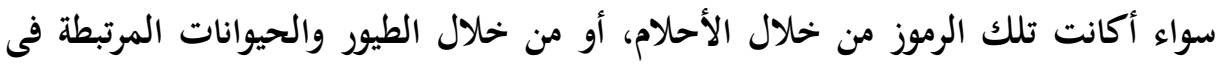

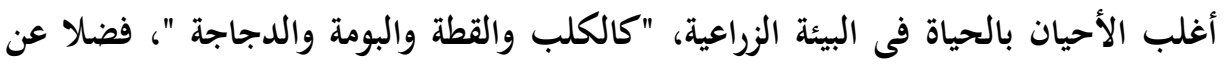

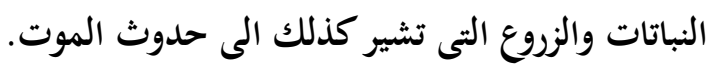
وساعد المنهج الأيكولوجى كذلك على توضيح الأسس التى تم على أساسها

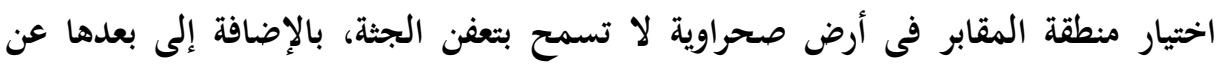

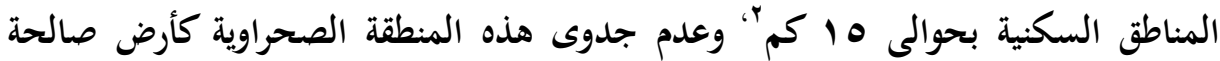
للزراعة.

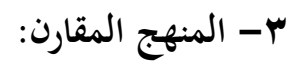

وهو المنهج المستخدم فى العديد من الدراسات فى حقل العلوم الاجتماعية

بهدف الخروج بنتائج عن المرحلة الزمنية سابقة عليها، حيث لا تصح سمات وخصائص

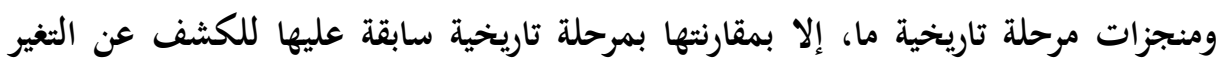

$$
\text { الحادث فى المجتمع وأبنيته. }
$$

ويتميز المنهج المقارن بأنه يتوصل إلى مفاهيم مجردة عن الظروف الزمانية والمكانية

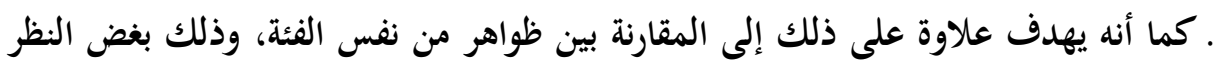

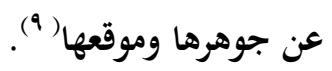
وقد استفادت الدراسة من المنهج المقارن فى توضيح عدة متغيرات أساسية هى :1-الكشف عن مدى التشابه والاختلاف بين كل من عادات الموت وممارساته وطقوسه فى مجتمع الدراسة وبين عادات الموت فى مجتمعين تقليديين من الريف والحضر. 
ץ-رصد عادات وتقاليد المجتمعات الريفية التقليدية من خلال ماتوصلت إليها نتائج المرحلة الزمنية محل الدراسة ومقارنتها بنتائج الدراستين اللتين أجريتا فى مرحلة زمنبة سابقة.

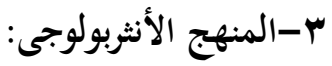

لعب هذا المنهج دوراً مهمّا في هذه الدراسة، فأسهم في اختيار منطقة

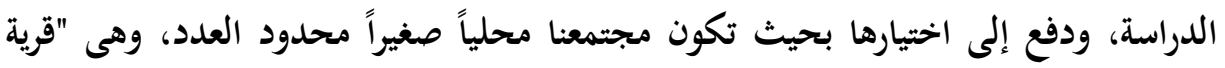
العبور" بمحافظة الإسماعيلية، وذلك للتمكن من تغطية كافة جوانب موضوع الدراسة في فترائ فحترة زمنية معقولة) (1)

وقد كان للوسائل التي أشار إليها المنهج الانثروبولوجى لجمع مادة البحث ميدانياً

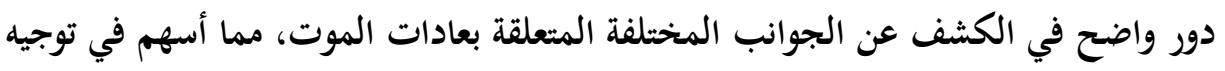
مسار البحث وإثرائه بالمادة المطلوبة، وذلك من خلال تطبيق دليل الئل العادئ العادات والتقاليد الشعبية كموجه للملاحظة، والملاحظة بالمشاركة، والمقابلات المتعمقة.

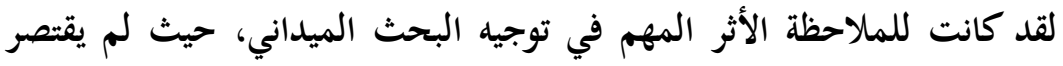
استخدام هذه الوسيلة على ملاحظة عادات الموت من حيث المكان والزمان اللذين تتم

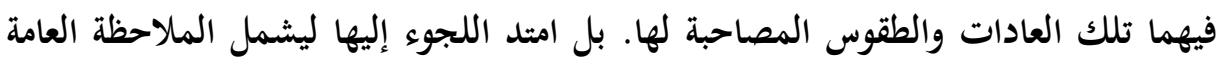

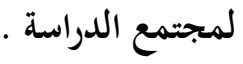
وقد أسهم ذلك في التعرف على الكثير من جوانب الحياة التي تدفع لفهم أكثر الكرا

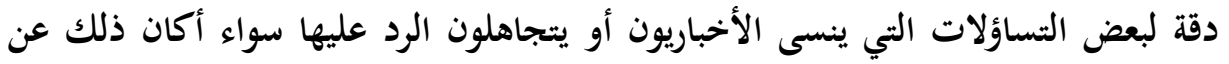

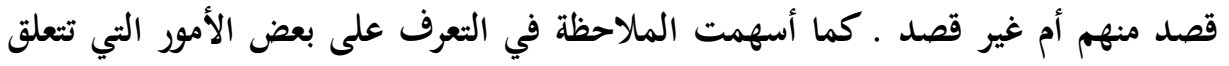
بسير الجنازة والعزاء وكيفية دخول المعزين واستقبالهم . وكانت الملاحظة من خلال المشاركة الأثر الكبير في الإجابة عن بعض أسئلة الدليل بشكل أكثر واقعية، وقدرة على احتواء كافة عناصر السؤال دون اللجوء إلى الإخباريين إلا

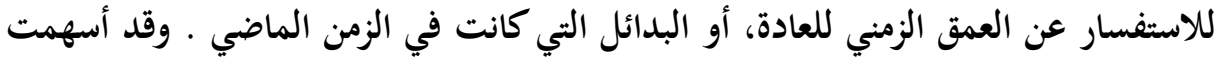

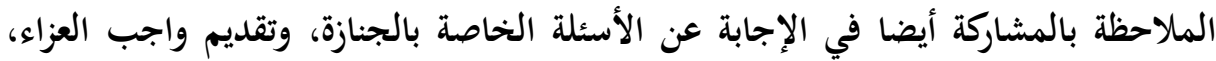
وكذلك التجهيز للغسل والتجهيز لاستقبال المعزين . 
وتعد المقابلة من أهم الوسائل التي أسهمت في التعرف على الأبعاد المختلفة للظاهرة

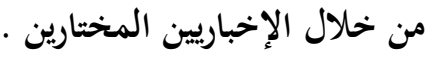
وقد ساعدنا فى اختيار هؤلاء الاخباريين وجود ثلاث طالبات ممن يكملون دراستهم العالية بالتعليم المفتوح، واللاتى تقوم الباحثة بالتدريس لهن فى برنامج "الإعلام والتنمية " في جامعة قناة السويس، ويقمن وينتمين لمجتمع الدراسة. إحداهما متزوجة من

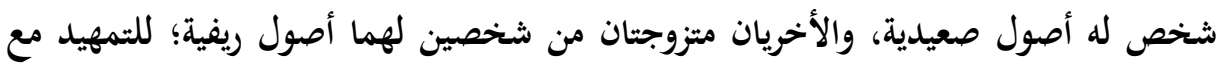
الإخباريين لإجراء المقابلات الأولية معهم، كما كان عليهن عبء التعريف الأولي بمهمة

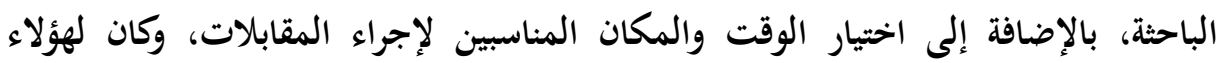

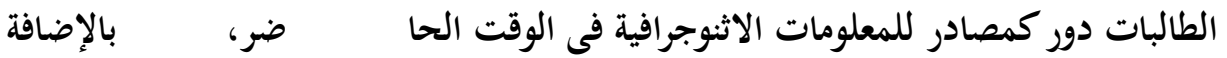
لدورهم فى التمهيد لإجراء الدراسة الميدانية منبثقاً من معرفتهما الوثيقة بالإخباريين وظروفهم

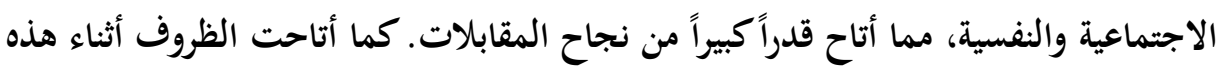

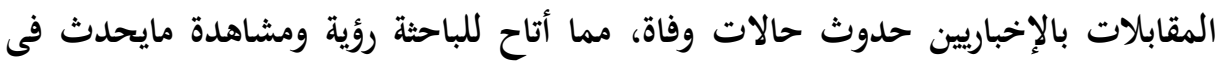
هذه المناسبات من واجبات العزاء وملاحظة الطقوس والمراسم والعادات التى تصاحب

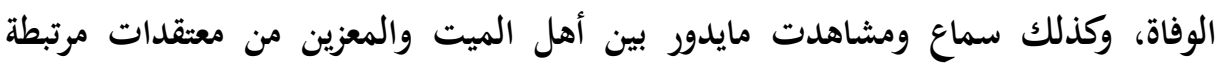
بالأحلام والرموز الدالة على قرب حدوث الوفاة والخميسان ....إلخ مدان وقداستعانت الباحثة بمستويين من الإخباريين من مجتمع الدراسة: المستوى الأول: إخباريون (كمصادر للمعلومات الاثنوجرافية) على قدر من الوعي والفهم يؤكدان استيعابهم لموضوع الدراسة والغرض منها، مما ساعد على توجيه الباحثة إلى لى إخباريين بعينهم لإجراء الدراسة الميدانية معهم، كما كان لاتصالهم المباشر بمجتمع الدراسة وعلاقاتهم الوطيدة بالإخباريين المختارين وبجماعة البحث بعامة أكبر الأثر في نجاح المقابلات. المستوى الثاني: تم اختيار ستة إخباريين اختيروا كوحدة للدراسة، وقد تم ذلك على أساس مايلى: اثنتان من أصل ريفي واثنتان من أصول ريفية صعيدية واثنتان من أصول ريفية بدوية، وقد أسهم كل ذلك في تحديد بعض الملامح المميزة لكل وحدة، ووضعها الطبقي داخل مجتمع الدراسة. 
وفد قامت الباحثة بدراسة حالات بعينها دراسة متعمقة، للوصول إلى معرفة الأحداث المهمة التى أدت الى إحداث تغيرات فى حياة تلك الحالات، وكيف تطورت أساليب سلوكها واتجاهاتها عند حدوث التغير خلال فترة زمنية محددة. باعتبار أن هذه الحالات مركبة

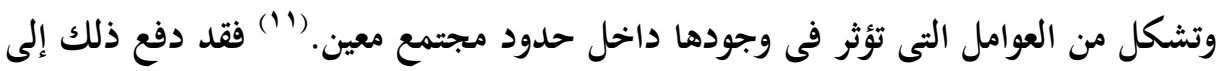

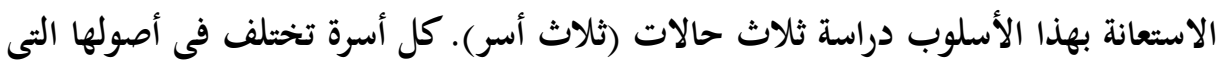

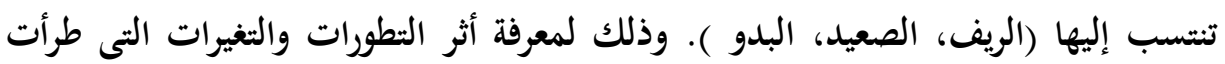
على أفراد أسرة كل منهم وعلى تصورات وطقوس عادات الموت، فتم اختيار بعض الإخباريين

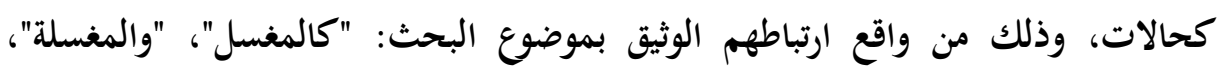
"والفقى"، "واللحاد، والملقن".

كما كانت الاستعانة بالإحصاءات الصادرة عن الجهاز المركزي للتعبئة العامة والإحصاء الدور الكبير في التعرف على مجتمع الدراسة وعلى موقع وأيكولوجية القرية، والأنشطة السكانية وبعض المنشئآت الحكومية لأهل المنطقة، وعدد السكان والأسر والمنازل.

ع - كما لجأت الدراسة إلى الاستعانة بالمنهج الفولكلوري بأبعاده الأربعة لما له من

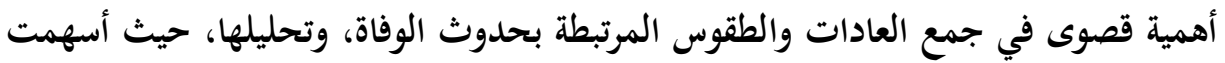

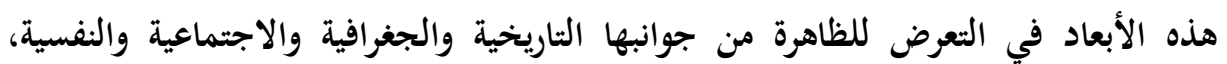
ويمكن أن نبين ذلك على النحو التالي :

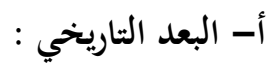

أسهم البعد التاريخي في دراسة عادات الموت في صورتها الحالية، ومحاولة تتبع التغيرات التي طرأت عليها للوقوف على مدى استمرار العادة، بالإضافة إلى التعرض لمحاولة

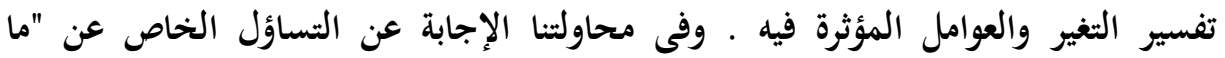
الأصول التى تعود إليها عادات الوفاة فى المجتمع المصرى المعاصر، وتظهر لنا بعض

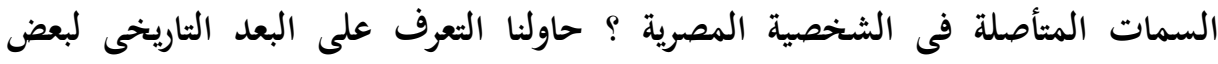
الطقوس والمراسم والعادات الخاصة بحالات الموت والتى لها جذور تاريخية. فليس عامل

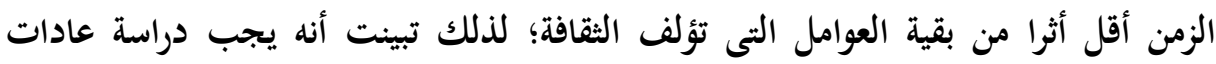


الموت والطقوس الجنائزية ودفن الموتى منذ عهد الفراعنة إلى الوقت المعاصر لكى يتضح

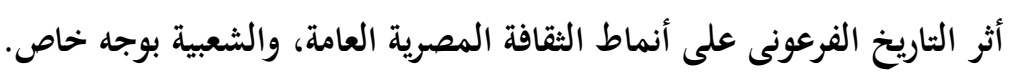

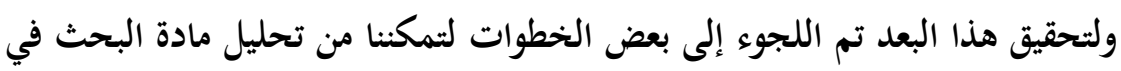

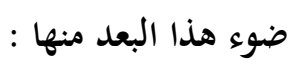
الرجوع إلى بعض الدراسات السابقة التي تتعرض لنفس موضوع الدراسة وبخاصة تلك الك الكيات

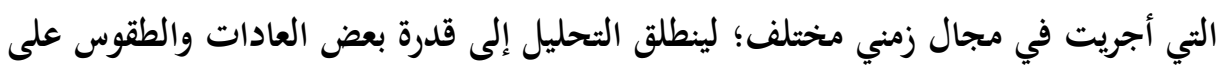
الاستمرار وإمكانية التغير.

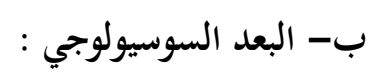

أسهم هذا البعد في تحليل الظاهرة من خلال أبعادها الاجتماعية، حيث حرصنا

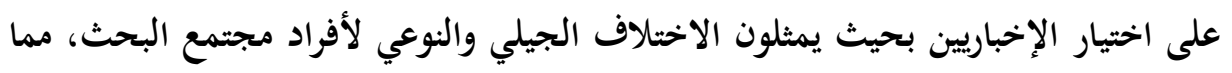

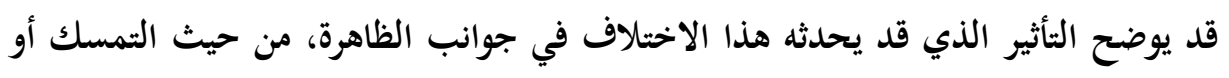

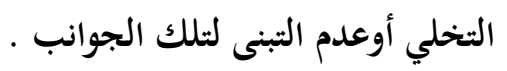

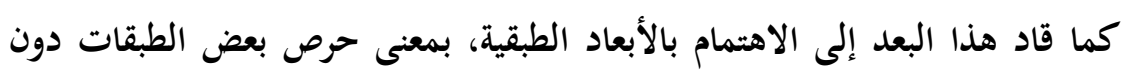

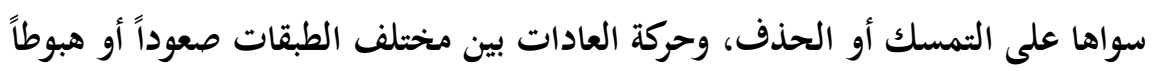

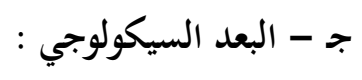

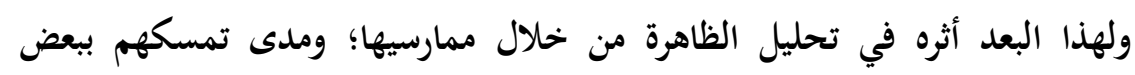
العادات المتعلقة بالموت، وذلك من خلال عوامل متعددة، منها: التنشئة والتقليد والاعتقاد التهاد

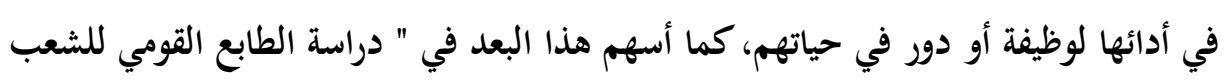
المصري كما يبدو في تراثه الشعبي (ir).

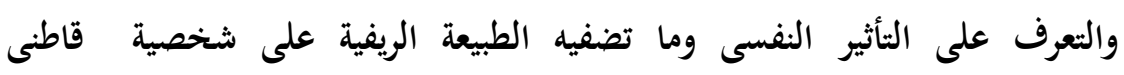

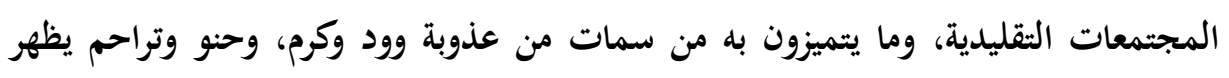

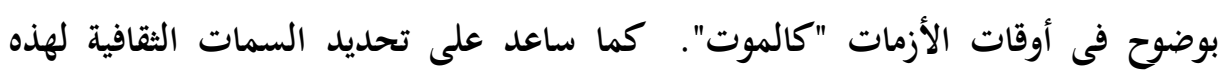

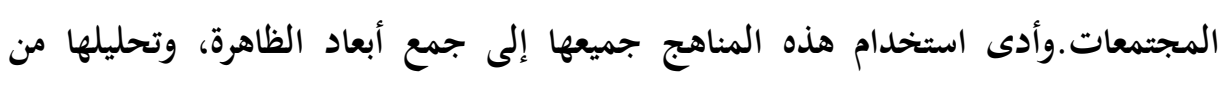

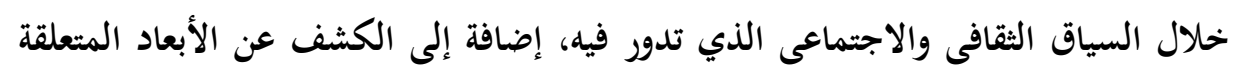


بمشكلة البحث، كما أسهمت هذه المناهج في استخلاص النتائج بشكل يتفق مع الهدف

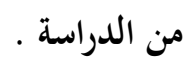

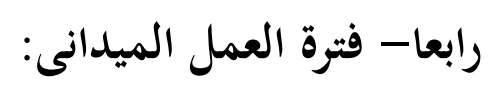

بدأ العمل الميدانى فى هذه الدراسة واستمر الاتصال بمنطقة البحث فى الفترة من

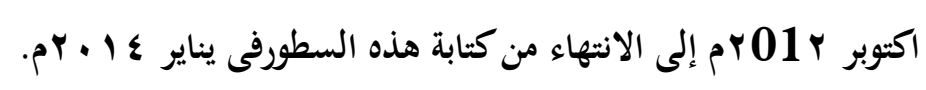

خامسا-القضايا النظرية للدراسة :

حاولنا اختبار قضايا نظرية فان جنب" طقوس العبور "("') سواء في الجمع الميداني، أو

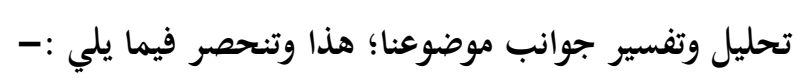

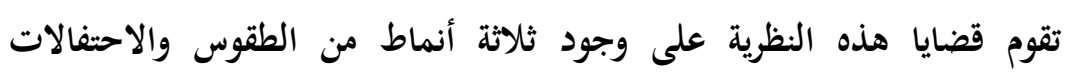

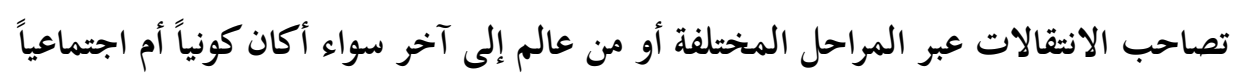

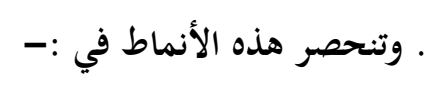

- طقوس انفصال، طقوس اندماج، طقوس انتقال .

\section{وقد استعانت الدراسة بقضايا نظرية "فان جنب" Arnold Van Gennep}

(190V-1AVT) (") كإطار نظرى يتيح لها دراسة ظاهرة البحث والوصول إلى النتائج

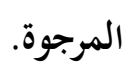

وتقدم دراسة "فان جنب" منظورا مهما بخصوص طبيعة طقوس الموت فى جوانبها

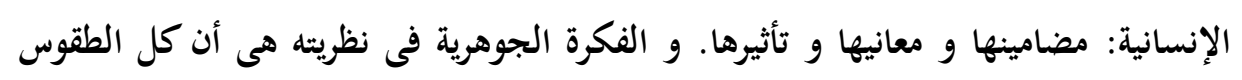

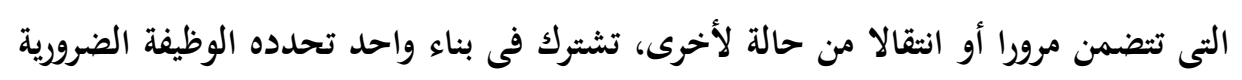

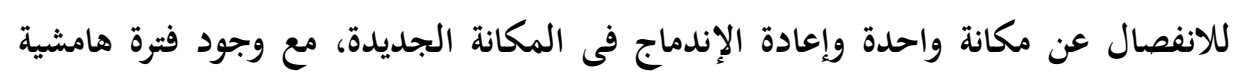

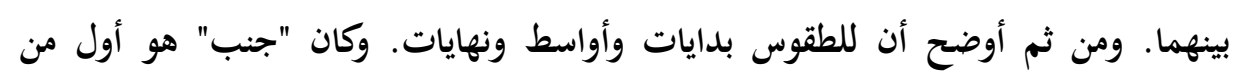

(") 9.91 نشر كتابه الثهير: شعائر المرور the Rites of passage أوضح فيه أن معظم المجتمعات لها طقوس تمبيز انتقال الأفراد من مكانة لأخرى، كما تتاول فيه الطقوس الجنائزية أيضا.

انظر: Paul Ghiberti and Edger V. Whininess, Culture Anthropology (Philadelphia J.B .Lippincott Company, 1976, p.169 
لاحظ مدى تماثل البدايات والأواسط والنهايات فى مجموعة كبيرة من الطقوس، وأكد فى ذلك أن هذه التشابهات ليست عشوائية، ولكنها جزء من ظاهرة عامة واحدة، وأ ن البناء أو الو الإطار العام الذى يشكل أساس مجموعة كبيرة من السلوك الطقوسى يرتبط بالوظيفة الاجتماعية لتعبئة ودمج الأفراد الذين ينضجون ويكبرون ويموتون فى ظل نسق محدد من الأدوار والمراكز المحددة ثقافيا، وتدل هذه الوظيفة على أن المجتمع يعيش ويستمر ويبقى على الرغم من اختفاء بعض أفراده على لونى

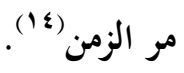

ومسح "فان جنب" لطقوس الموت فى أنحاء العالم يركز على الطرق التى

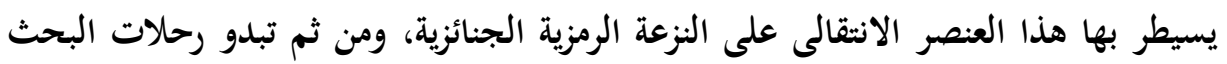

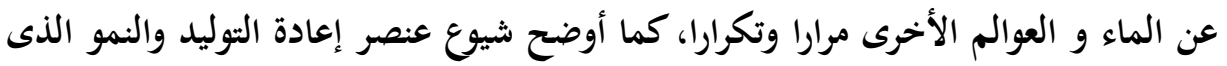
جرى التعبير عنه فى رموز الخصوبة الإنسانية والزراعية . وقد أوضح فان جنب أن للطقوس الجنائزية أربع وظائف رئيسة هى: أ- التصرف فى الجثة وإعداد الروح لوجودها الجديد: والعنصر الأخير قد يتضمن

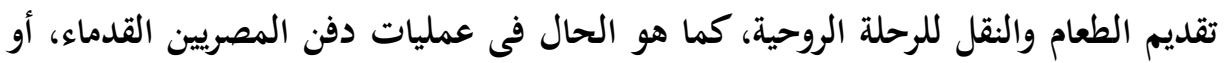

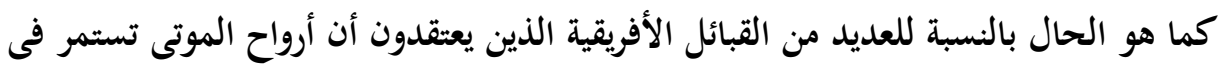
نشاطها كمشاركة فى شئون الحياة اليومية"). ب-نقل تعبير الحزن وتقديم الدعم وتهدئة نفوس الأقارب وأصدقاء الميت، فالموت

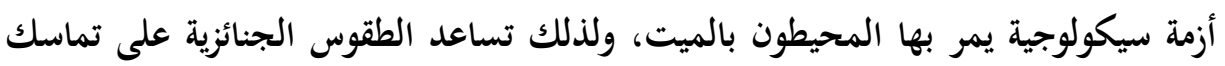

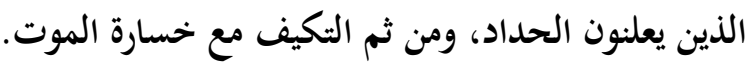
ج- استعادة توازن العلاقات الاجتماعية للأحياء حيث يتم القيام بطقوس منظمة تحند يعاد من خلالها توزيع الأدوار بغية استمرار المجتمع فى البقاء .

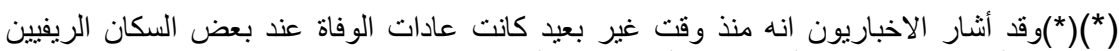

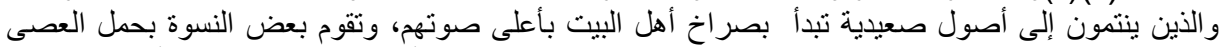

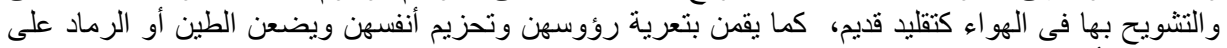
رؤسهن ويأتى الرجال مسر عين ويقو مون بالتعزية. 
د- إعادة تأكيد المعتقدات والمعنى العام الذى تضفيه الثقافة على الحياة

فى بقاع مصرنا الحبيبة تختلف بالضرورة طقوس الجنازات والمآتم من محافظة إلى أخرى، ومن قرية إلى قرية فى نفس المحافظة. رغم أنهم يجتمعون فى النهاية على رباط

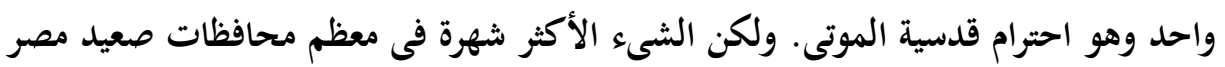

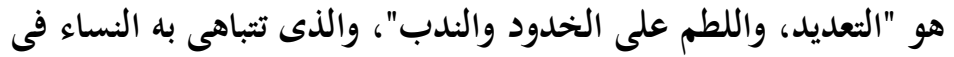

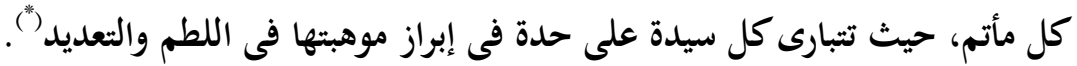

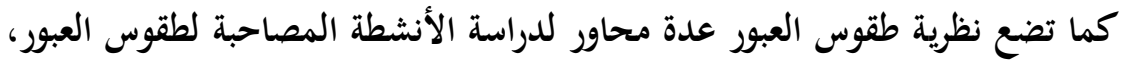

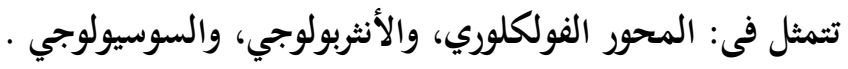

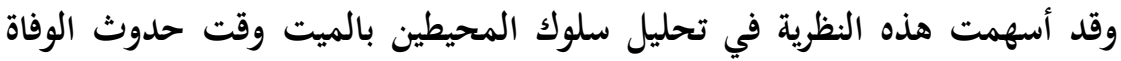
وبعدها، وكيف يقومون بمساعدة المحتضر فى الانفصال من الحياة الدنيا بقراءة سورتى

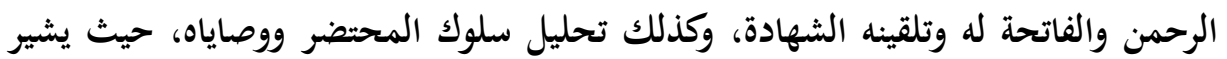
جانب كبير من سلوك المحتضر ووصاياه إلى محاولاته الانفصال عن حياته الأولى. سادسا-الدراسات الميدانية المقارنة: لجأت دراستنا الحالية إلى تحليل ثلاث دراسات ميدانية تعرضت لعادات الموت من قرى المجتمع المصرى، وقد تم دراستهم فى مناطق مختلفة ومنذ حوالى ربع قرن.

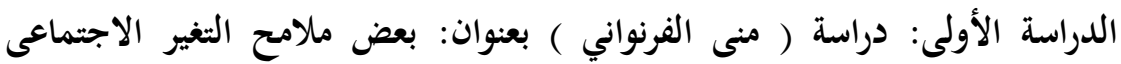
والثقافى فى الريف المصرى كما تعكسه عادات دورة الحياة "دراسة متعمقة لقرية مصرية"

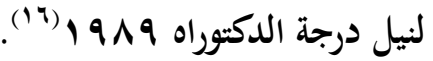

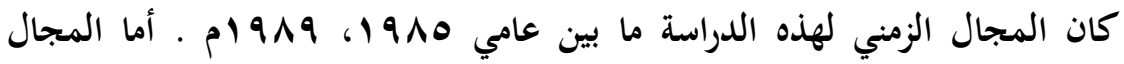
الجغرافي لها فقد اختارت له الباحثة قرية " البراجيل " التابعة لمحافظة الجيزة. وتدور الدراسة حول عادات دورة الحياة: الميلاد والزواج والموت في تسعة فصول. وقد اختص الفصل الثامن من الدراسة بعادات الموت وشمل الاستعداد للموت، والتجهيز للميت، والدفن والحداد. واشتمل الجزء الخاص بالاستعداد للموت على: استعداد الحي للموت والعلامات التي تنبئ بوقوع الموت، وسلوك الميت والمحيطين به قبيل وبعد الوفاة، 
وإعلان الوفاة ـ كما اشتمل الجزء الخاص بالتجهيز للميت على: الغسل، القائم بالغسل،

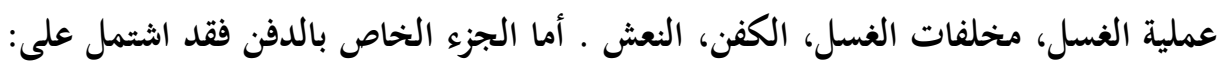

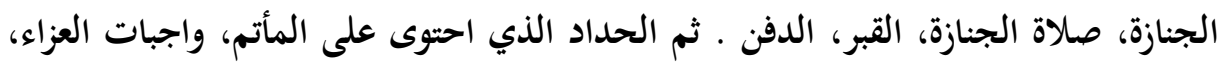

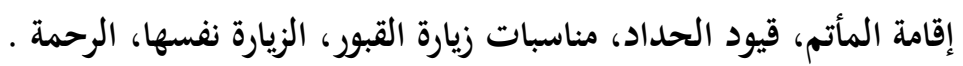

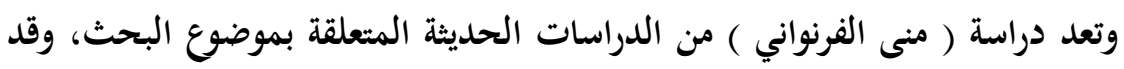

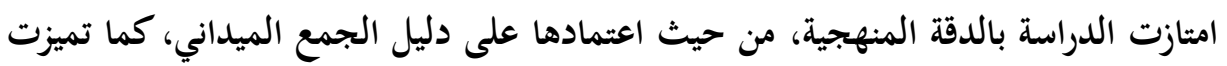

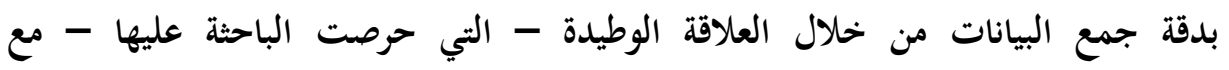

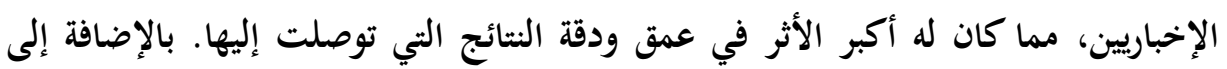

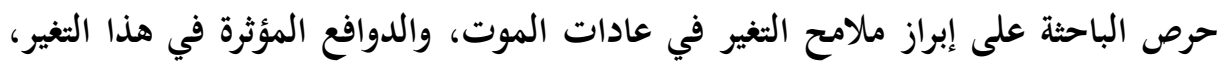

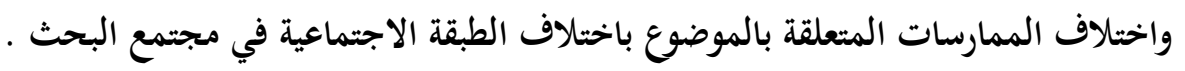
وقد استفاد هذا البحث من هذه الدراسة من حيث مقارنة ماجاء بها عن عادات

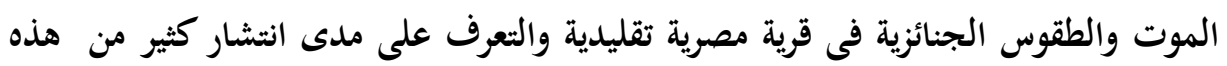
العادات واستمرارها فى مجتمع الدراسة "قرية العبور".

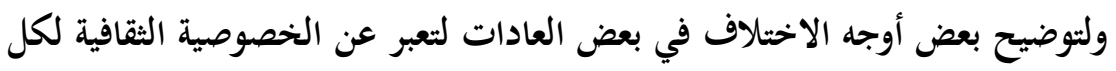

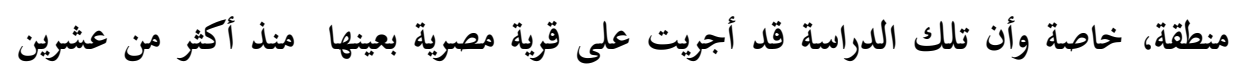

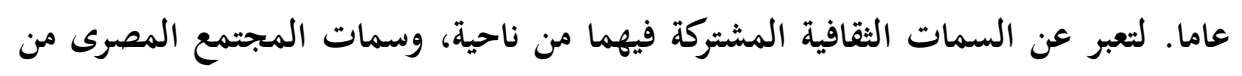
ناحية أخرى.

الدراسة الثانية: دراسة (سميح عبد الغفار شعلان) بعنوان: الموت فى المأثورات

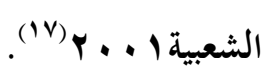

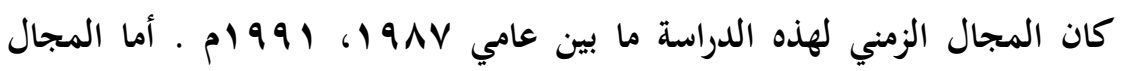
الجغرافي له فقد اختار له الباحث " كفر الأكرم " التابع لمحافظة المنوفية.

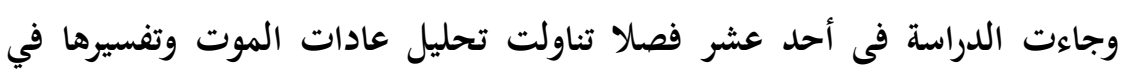
ثمانة فصول من "الفصل الثالث إلى الفصل الحادى عشر" حيث تناول الباحث في الفصل 
الثالث دراسة العلامات التى تنبى بوقوع الموت (الأحلام، سلوك الأحياء المنبأ بوفاتهم، سلوك بعض الحيوانات والطيور، وتناول فى الفصل الرابع الوفاة وإعلانها والخامس التجهيز

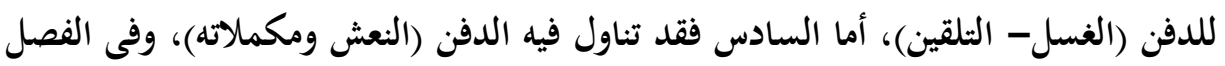
السابع فقد تناول فيه العزاء(العزاء على القبور، العزاء على المآتم، العزاء فى المناسبات)، والثامن زيارة القبور والرحمة(الزيارة ومحدداتها)، فى الفصل التاسع والعاشر الحداد والقبر، والأخير عن التعديد (نماذجه والندب). وتعد دراسة (سميح شعلان) أحدث الدراسات المتعلقة بموضوع البحث، وقد امتازت الدراسة بالدقة المنهجية، من حيث اعتمادها على التكامل المنهجى ودليل الجمع الميداني،

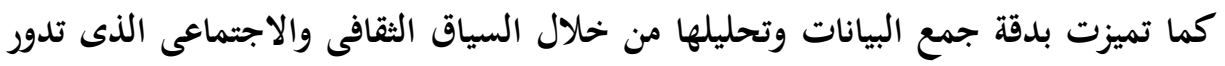

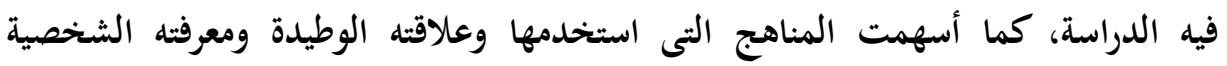
للإخباريين، مما كان له أكبر الأثر في عمق ودقة النتائج التي توصل إليها.

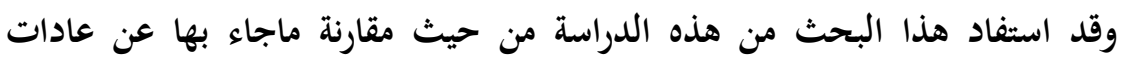

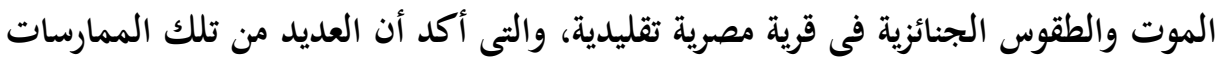
والطقوس تتمتع بثبات ممارستها مع جذورها المصرية القديمة، وذلك لقدرتها على آداء وظائف ثابتة، كما أكدت تلك الدراسة على مدى انتشار كثير من هذه العادات وتشابهها واستمرارها فى مجتمع الدراسة "قية العبور"، وقد أوضحت دراسة "سميح" بعض أوجه الاختلاف أيضا في بعض العادات المتعلقة بالموت فى بين دراسته ومجتمع البحث فى هذه الدراسة لتعبر عن حركة تطور المجتمع المصرى من خلال انتشار الفهم الصحيح لتعاليم

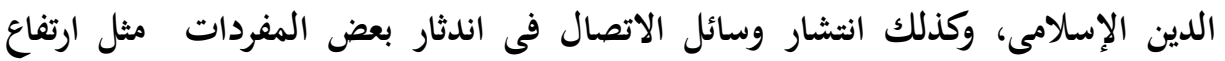
الثاهد على القبر عن الأرض، طقوس الندب وجنازة النساء من شق الجيوب ولطم الخدود ووضع الطين على الؤوس، كما ينطبق ذلك على المراثى الشعبية (التعديد)، بالإضافة إلى لى التخفف من قيود الحداد. وقد أجريت دراسة "سميح" على قرية مصرية بعينها فى فترة زمنية تسبق هذه الدراسة بأكثر من عشرين عاما وفى منطقة تقليدية مختلفة . 
الدراسة الثالثة: هى الدراسة الحالية "لقرية العبور" وقد قامت الباحثة بمقارنة ماتوصلت إليه دراسة كل من "منى الفرنوانى"، و"سميح شعلان". ودراستنا الحالية لمحاولة الوصول إلى السمات الثقافية التى تتسم بالثبات وتعد من سمات الشخصية المصرية. كما اتضح من خحلال الاطلاع على التراث النظرى الخاص بقدماء المصريين فى عصر الفراعنة؛ أنه لازالت تمارس إلى الآن بعض العادات والطقوس الخاصة بالموت مثل البكاء واللطم، الملابس السوداء، رثاء الموتى الموت إقامة المآتم والعزاء بعد أربعين يومُا ...إلخ. الإجراءات المنهجية لمجتمع الدراسة: أولا-أسس اختيار مجتمع البحث : وقد وقع اختيار الباحثة على قرية (العبور) بمحافظة الإسماعيلية مكانا لإجراء هذه الدراسة للأسباب التالية: - تتسم هذه القرية بنوعين من الإنتاج هما الإنتاج الزراعى، وأهم محاصيله "المانجو" و الإنتاج الحيواني "تربية الدواجن"، وهى السمة التي تشترك فيها هذه القرية مع المجتمعات الريفية التقليدية التي تنتج "محاصيل السوق، ذات العائد المادى المرتفع كنشاط اقتصادى. الأمر الذى قد يسهم فى ثبات عاداتهم التقليدية المرتبطة بالحياة الزراعية التى اعتادوا عليها منذ القدم، والتي تظهر بدورها فى طقوس وعادات الموت.

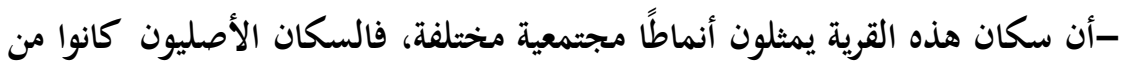
الريفيون البدو، ثم انضم إليهم العديد من أبناء ريف صعيد مصر، وأبناء ريف دلتا مصر،

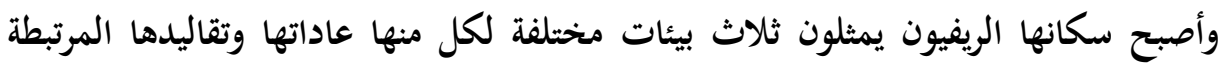
بالموت والتى تختلف من مجتمع إلى آخر. - قربها من العواصم الحضرية، حيث تبعد عن محافظة الإسماعيلية بمسافة ها كم. كما أن بهذه القرية تنمية زراعية - وتكاد تكون البطالة معدومة، ففرص العمل فيها لهوبه مفتوحة - وهو ما أدى إلى جذب الكثير من الأيدى العاملة من القرى والمحافظات المختلفة. 
- وجود وسطاء من سكان هذه القرية أتاح للباحثة بالتعامل الطبيعي والثلقائي مع التعائ الإخباريين الذين على معرفة دقيقة بأحوال مجتمعهم اليومية والمعيشية في الإجابة بتلقائية عن

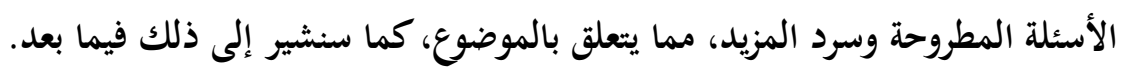

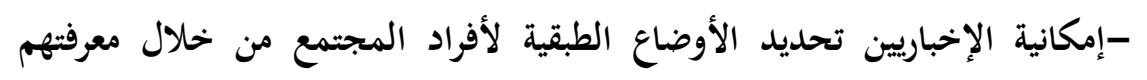

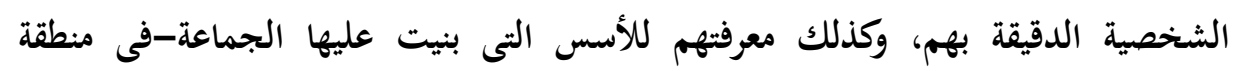

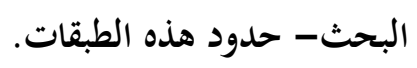

ثالثا-النتائج التحليلية للدراسة الميدانية:

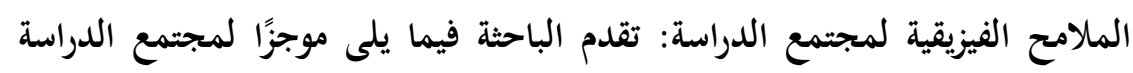

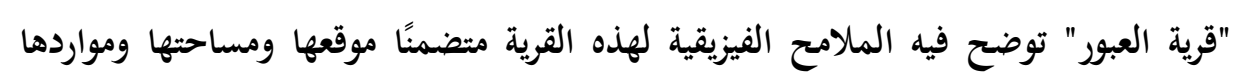

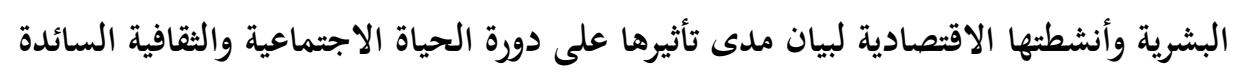

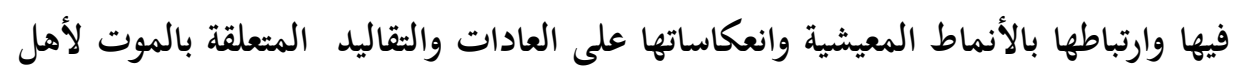
هذه القرية. الوصف الجغرافى للقرية :

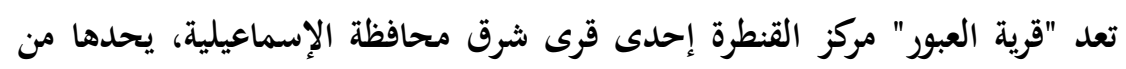

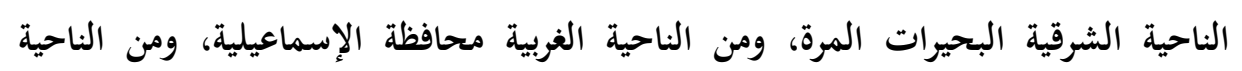

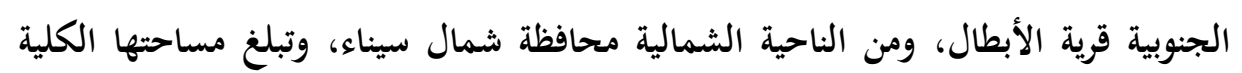

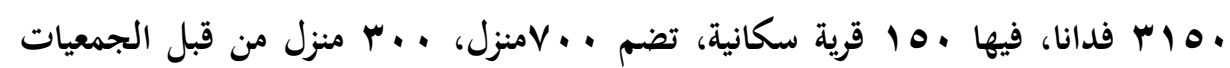

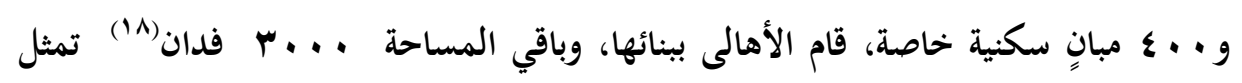
زمام الأراضى الزراعية بها. يوجد بقرية العبور مركز شباب واحد، يطلق عليه مركز شباب "قرية العبور"، ويتوفر به الهابه بعض الأنشطة مثل: لعبة كرة القدم، ألعاب جيم(حديد)، مكتبة للإطلاع فقط لهابل للأطفال

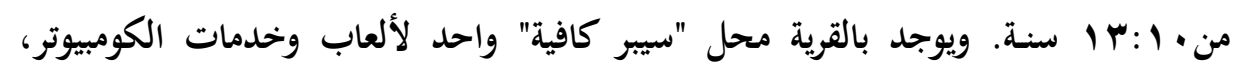

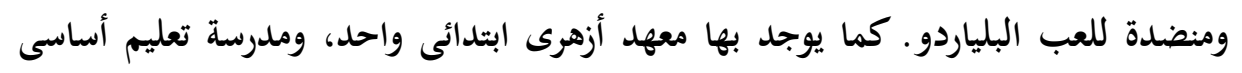

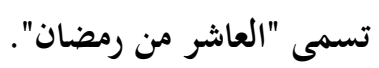


الموارد البشرية للقرية: يبلغ تعداد القرية . •هه نسمة وفقا لتقرير الجهاز المركزى

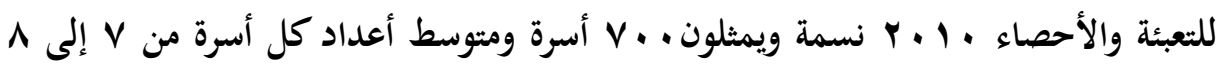
أفراد. النشاط الاقتصادى للقريـة: يمثل النشاط الزراعى أهم الأنشطة الاقتصادية في القرية،

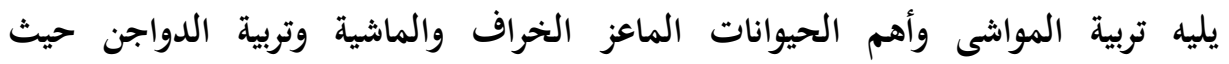
توجد"عشش" الدواجن في معظم المنازل، بالإضافة إلى مزارع الدواجن البيضاء المنتشرة

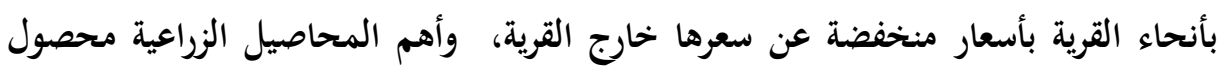

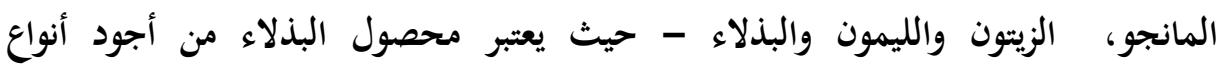
البذلاء(بدون حبوب) وتصدر للخحارج - بالإضافة إلى زراعة القمح، والذرة، البرسيم،

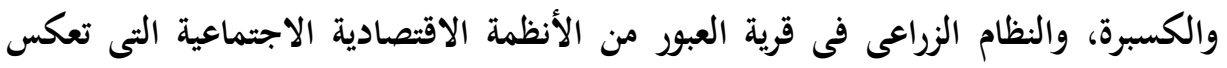

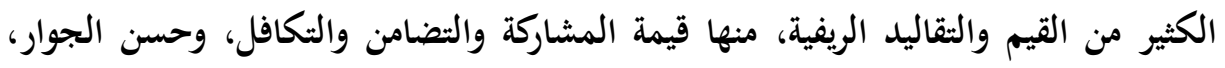

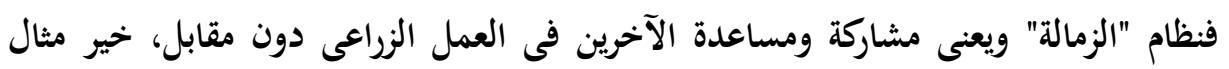

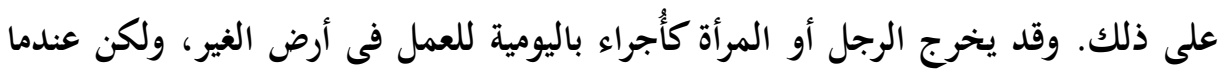

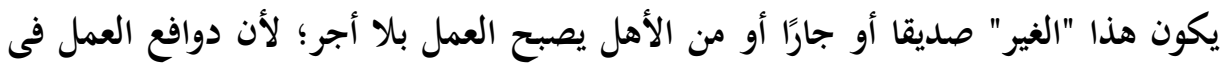
هذه الحالة تختلف، فهى دوافع المحبة والمشاركة وهى من قيم القرية المصرية.

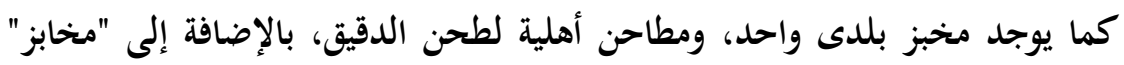
أهلية - "فرن فلاحى" لعمل الخبز - وهى منتشرة في غالبية المنازل، فلا توجد أزمة خبز في لإحند

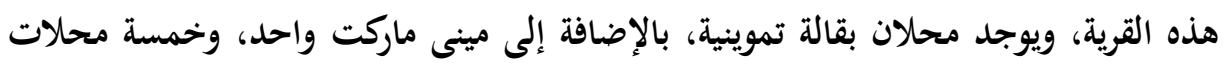
فول وطعمية، وشركة كبيرة تسمي "شركة الهدى للفاكهة والخضروات" ومصنع ملحقا بها،

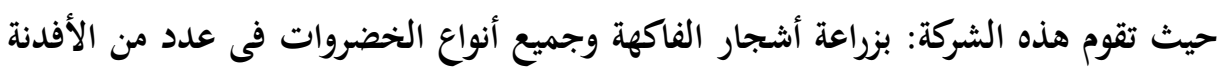

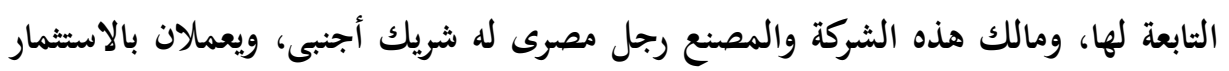

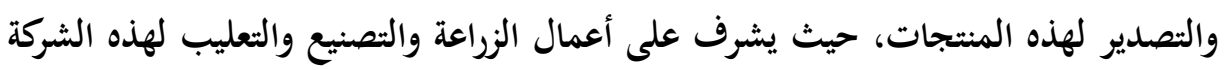
أجانب، وهم يعتمدون على الأسمدة الطبيعية " العضوية" غير الصناعية فى الزراعة، لذا تتميز منتجات الشركة بالجودة العالية وحسن المذاق والإنتاج الوفير. 
وهذه الشركة توفر فرص عمل كثيرة لغالبية الثباب بالقرية، وتوفر فرص عمل أيضًا

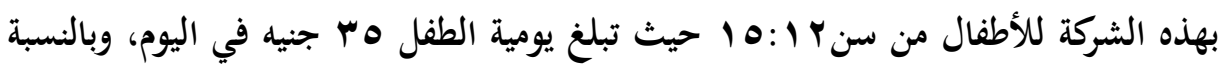

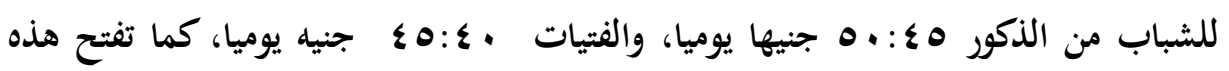

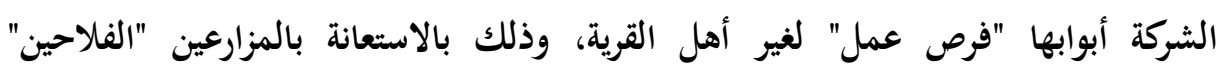

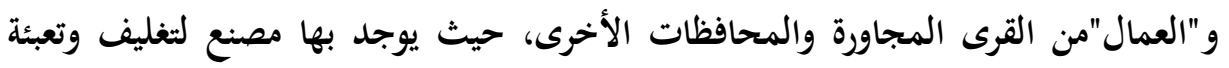

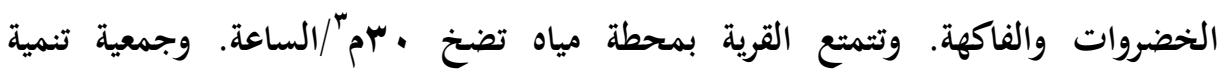

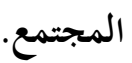

شكل المنازل: تتشابه شكل المنازل إلى حد كبير جدًا، حيث وزعت المحافظة على ألى

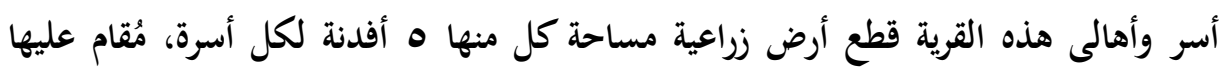

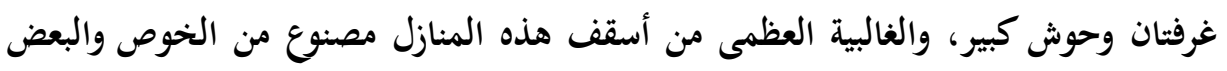

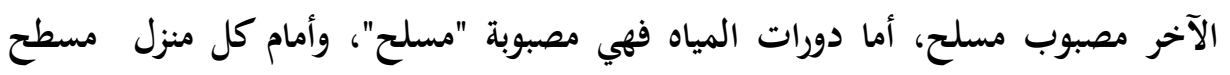

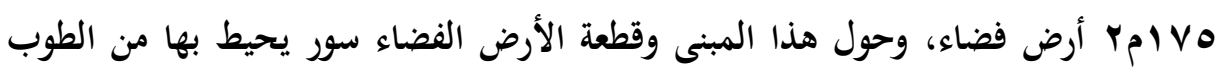
الأسمنتى، وإذا رغب أحد السكان فى توسيع منزله، يمكنه الاستفادة من اله Vا امب الفضاء الفضاء

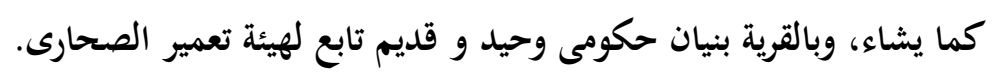

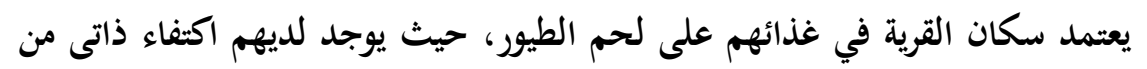

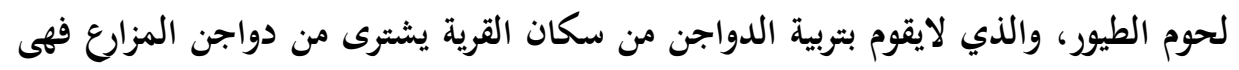
متوفرة ورخيصة الثمن، والفائض من هذه الطيور يأتى تجار الجملة لشرائه ويقوم بتوزيعه وبيعه لئه

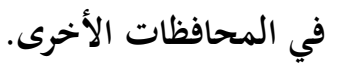
واقتصاد قرية العبور يقوم أساسًا على محصول المانجو، فأى مناسبة من المناء

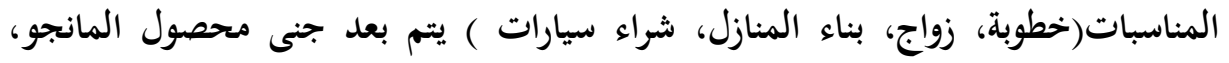

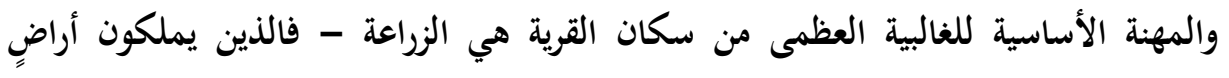

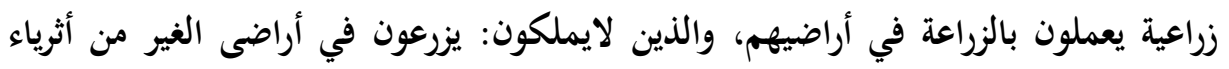

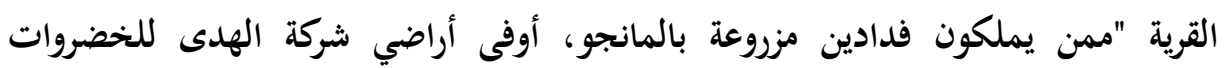

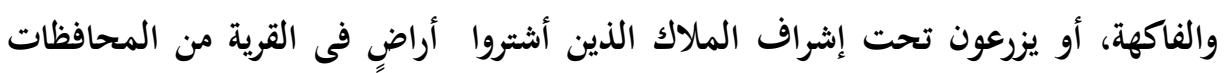

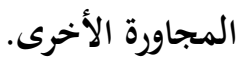


أهم الحيوانات: الخراف والماعز والماشية ويعتمدون فى غذائهم على الطيور كما سبق الذكر. سوق الأحد: يقام سوق الأحد فى قرية مجاورة لقرية "العبور"تسمى قرية "الأبطال"

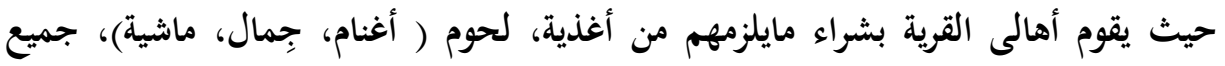
الخضروات والفاكهة، الملابس، وكل ماتحتاجه العرائس من جهاز وأدوات كهربائية.

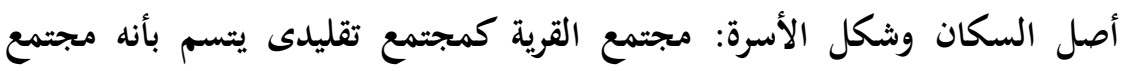

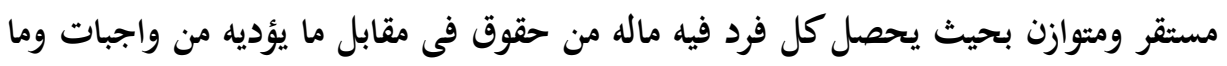

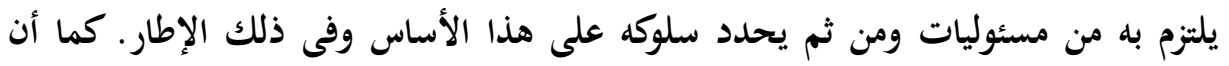

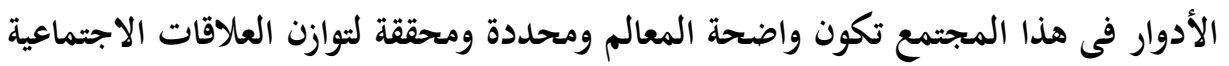

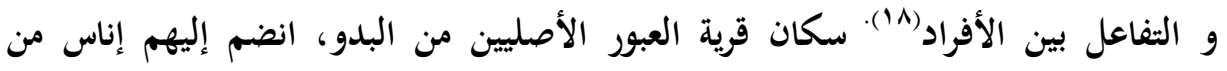

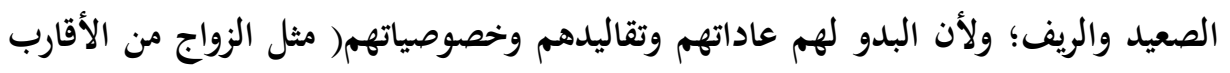
traditional extended "فقط، وتعدد زوجات، ونمط الأسرة هو "الأسرة الممتدة

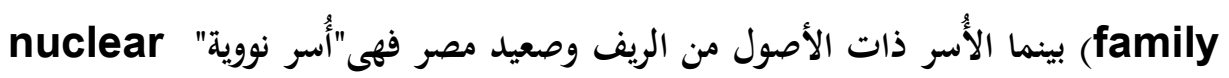
family وخاصة بين الأزواج المتعلمين الذين يفضلون الاستقلال بحياتهم وتربية أولادهم بأسلوب "حديث" يرونه أفضل من من الأسلوب الذى نشأوا في ظله.

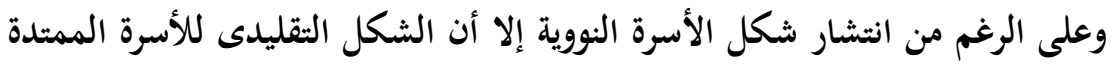

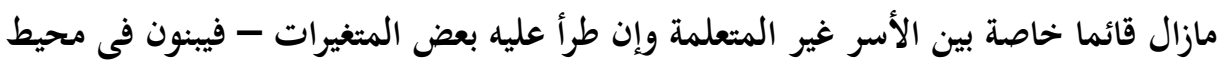

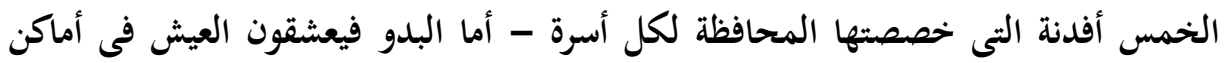

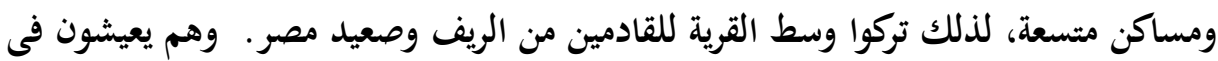
أطراف القرية، وبنوا بيوتهم على مساحات واسعة. والأسرة فى قرية "العبور" تقوم على تقسيم العمل طبقا للجنس والسن. فتقوم نساء

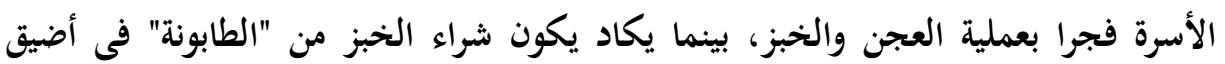

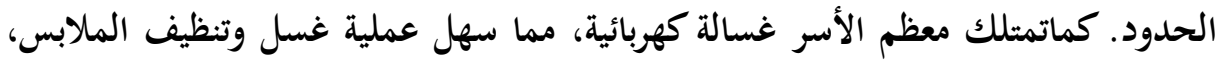
وتلثف الأسرة كلها لمشاهدة التلفاز "القنوات المحلية فقط أما الفضائية فمحرمة عادات الموت فى مجتمع الدراسة 


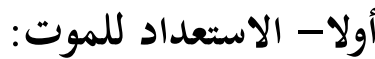

سنتناول فيما يلى الاستعدادت التى يقوم بها أهل المتوفى استعدادا للموت. فهناك

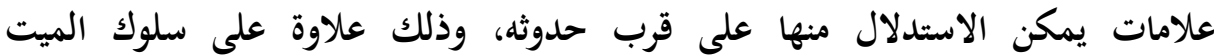
"المحتضر " والمحيطين به قبل وبعد الوفاة. استعداد الحى للموت:

تتضمن الاستعدادات للموت فى مجتمع الدراسة جانبين الأول: يشمل الاستعدادات

$$
\text { المادية والثانى: يتضمن الاستعدادات الروحية. }
$$

تجهيز الكفن: و يتكون من: Y سترة من القماش أحداهما قطعة قماش كبيرة ومستطيلة من "البفتة"، والأخرى قطعة توازيها فى الحجم من الستان "الأبيض والأخضر" أما لهان سترة المرأة "الكفن" يتكون من جلباب و طرحة باللون الأبيض.

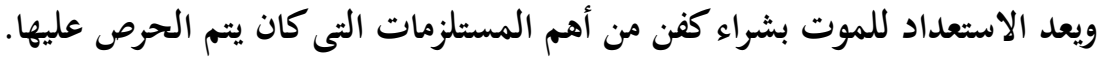
توجد جمعية تسمى "جمعية دفن الموتي" بمجتمع الدراسة، يديرها شخص تم ترشيحه من قبل أهل القرية، "وهو يتمتع بالأمانة والنزاهة وحُسن السمعة"، حيث يقوم بجمع عشر جنيهات شهريا من كل منزل بالقرية، وتخصص هذه النقود لحالات الوفاة فى القرية، وأحيانا بكفن أيضا للمتوفى يعطى لأهله في حالة الموت فجأة أوعدم المقدرة، على أساس أس أن يقوم"أهل المتوفى" بعد ذلك بشراء كفن آخر بدلا منه، وفي حالة عدم المقدرة لايلزم (").

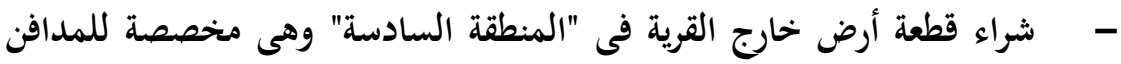

$$
\begin{aligned}
& \text { وتبعد عن مجتمع الدراسة بحوالى } 0 \text { اكيلو متر. } \\
& \text { ثانيا -الاستعدادات الروحية وتتمثل فى : } \\
& \text { - - الوضوء والصلاة قبل النوم خوفا من الموت المفاجىء. }
\end{aligned}
$$

(*)ويوجد جمعية أخرى لمساعدة المرضى بالدواء، وبالنقود حيث تقوم كل أسرة بدفع مبلغ على حسب

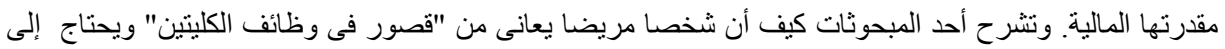

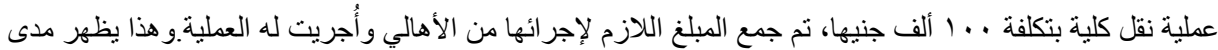

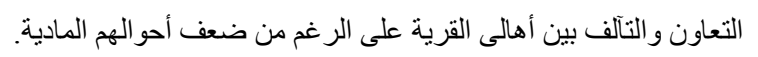


- - - - استرضاء من يشعر المحتضر أنه قد أخطأ فى حقه.

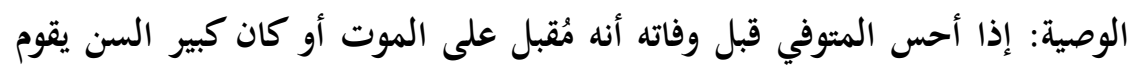

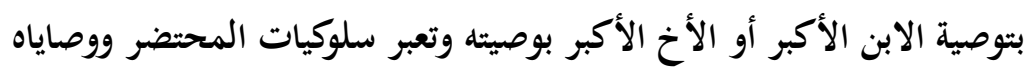

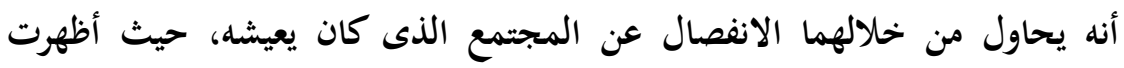

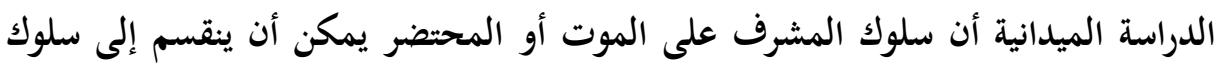

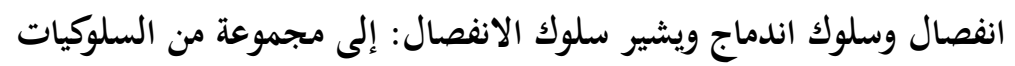
تهدف إلى انفصال الميت قبل الوفاة مثل البوح بأسراره ووصاياه، طلب الأحبة

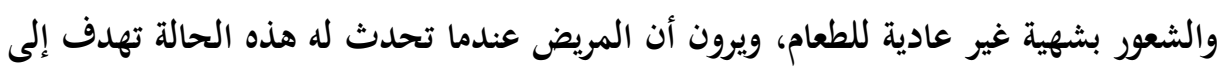

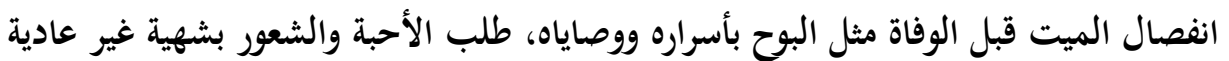

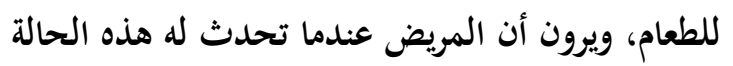
بأنها "صحوة الموت".وسلوك الاندماج: وهو يثير إلى مجموعة من السلوكيات تهدف إلى إدماج الميت بعد الوفاة بصورة طيبة فى حياته الآخرة مثل: الندم وطلب

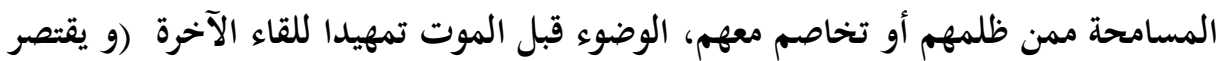

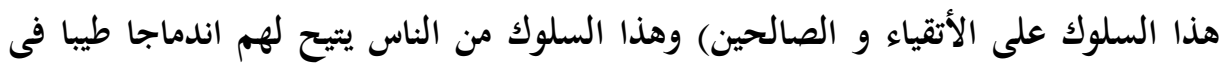

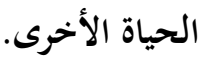

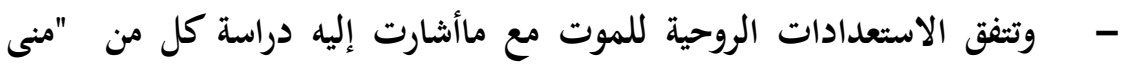

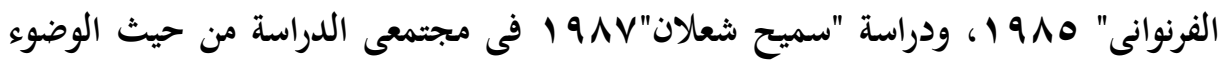

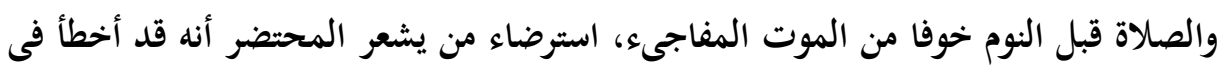

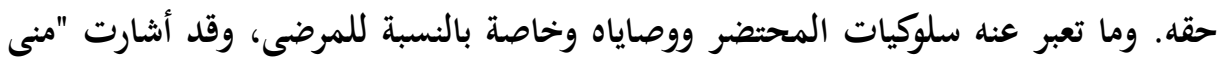

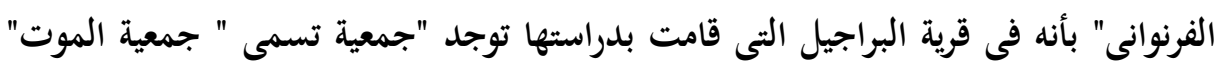

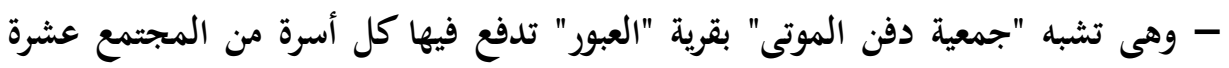
قروش شهريا- والاختلاف فى الاشتراك الشهرى يرجع إلى اختلاف قيمة العهيه العملة للفارق

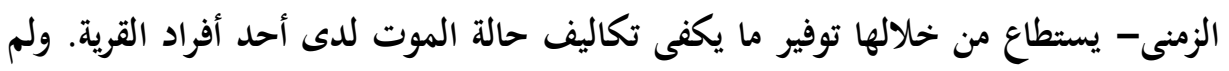

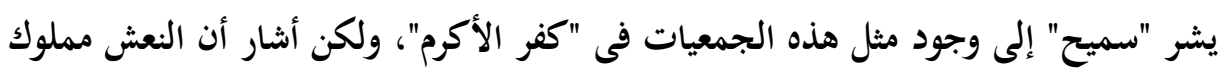


للجماعة، ويتم من خلال التبرعات، وفى بعض الأحيان يتولى أحد الأثرياء الأنفاق على عمل

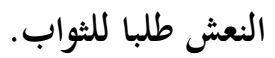

- وهذا يؤكد سمة من سمات المجتمعات الريفية التقليدية وهى التعاون والتضامن ورقة المشاعر والتآزر وقت الشدائد.

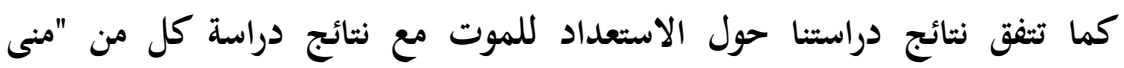
الفرنوانى"، و"سميح شعلان" فى الجانبين المادى والروحى مع اختلاف طفيف فى الإجراءات

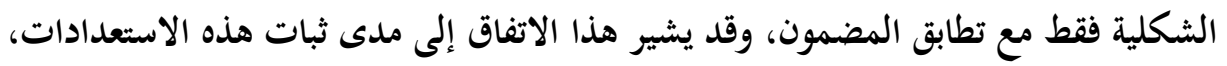
على الرغم من اختلاف الأماكن والأزمنة التى تمت فيها دراستهما.

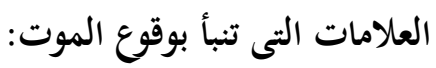

هناك علامات أجمع عليها المبحوثون فى مجتمع الدراسة تحدث قبل الموت.

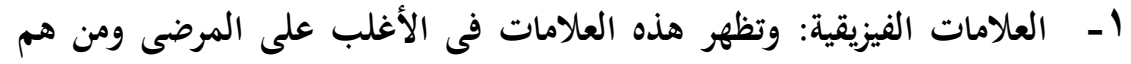

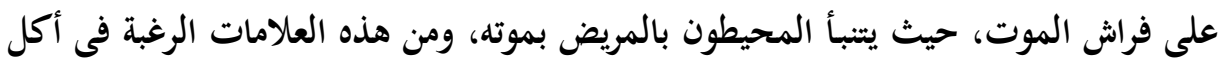

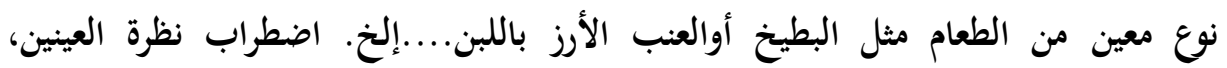

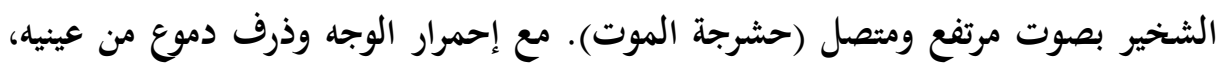

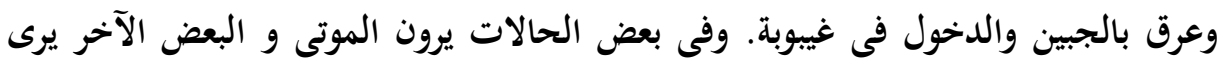

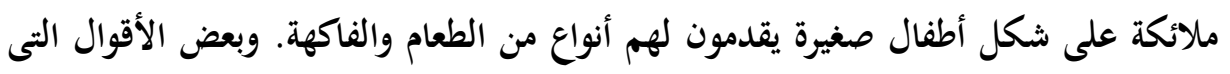
تصدر عن المحتضر بقرب ساعة وقوع الموت.

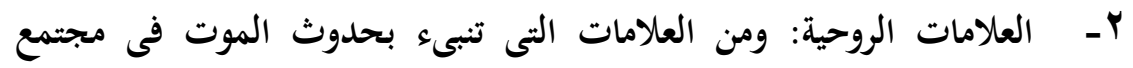

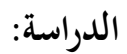

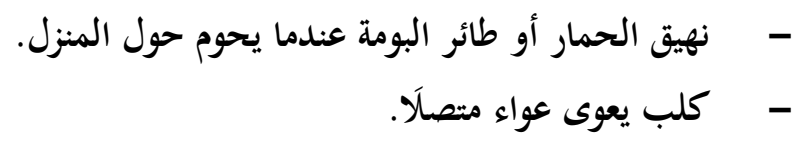
- - - أحلام ورؤى تفسر بأن أحد أفراد العائلة سينتقل إلى رحمة الله.

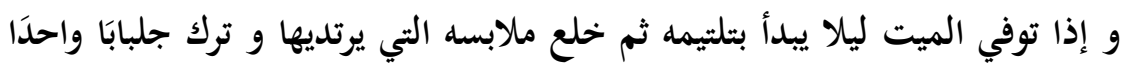

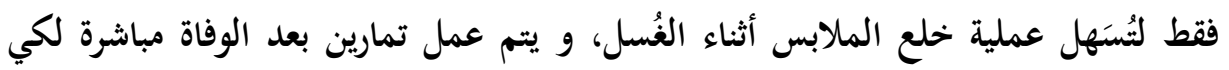
يظل الجسم مرنًا، وذلك بتحريك أطرافه( تكرار فرد وثنى الذراعين والساقين)، ثم يقومون 
بتشغيل شريط للقرآن الكريم على جهاز التسجيل بجواره ـ ويقوم أهله وأقاربه بتقبيله -قبل

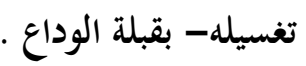

وتتفق دراستنا مع دراسة كل من "منى الفرنواتى "، و "سميح شعلان" فى العلامات

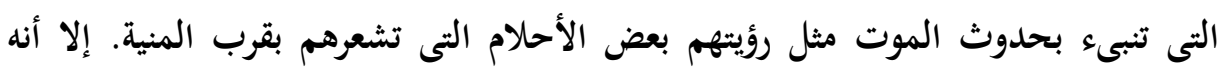

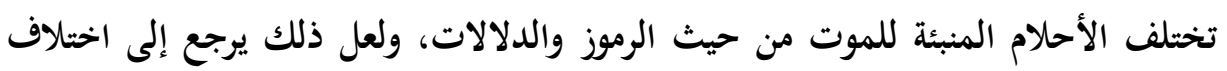

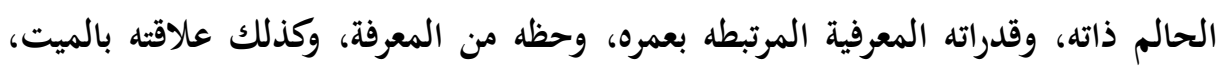

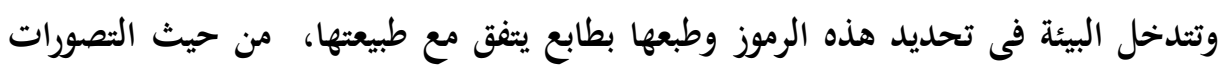

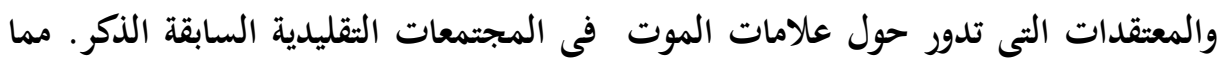

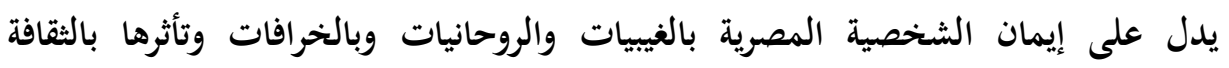
الشعبية وتراثها الاجتماعي بمختلف طبقاته الاجتماعية و مستوياته التعليمية المتنوعة. ويقول عباس العقاد: " لقد شاع عن المصريين أنهم أتقياء إلى حد الحماسة، يؤمنون بقضاء الله المطلق فى الخير والشر، ولقد أدى بهم تدينهم إلى الإيمان الكامل بالقدرية

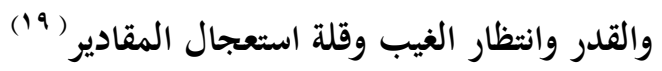

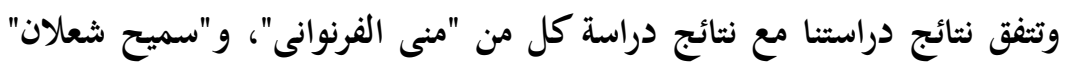

من حيث العلامات الفيزيقية التى تدل على قرب خروج روح المحتضر،، وكذلك رؤية

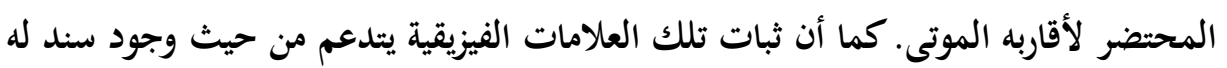

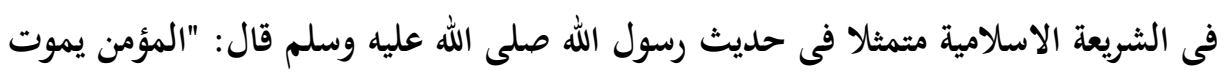
بعرق الجبين"، وكذلك روى عن سلمان الفارسى انه قال سمعت رسول الله صلى اللى الله عليه وسلم يقول :أرقبوا للميت عند موته ثلاثا" إن رشحت جبينه وذرفت عيناه وانتشر منخراه،

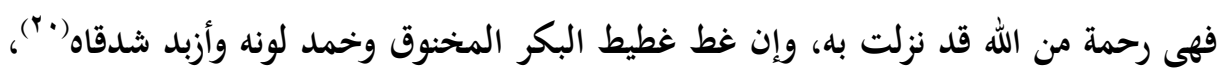
وقد يشير إلى ثبات هذه العلامات وانتشارها فى المجتمع المصرى.

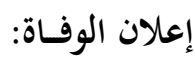

يتم إعلان الوفاة فى مجتمع الدراسة عن طريق مسجد القرية أو سيارة بها

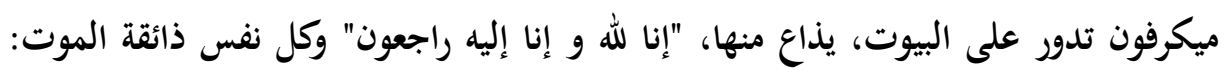
انتقل إلى رحمة الله "فلان ابن فلان" والد كل من "فلان وفلان" . . وعم"......و......"، ويذاع 
أسماء المشهورين من العائلة، و"الدفنة" بعد الصلاة ظهرا أو عصرا (حتى لايدخل المقابر

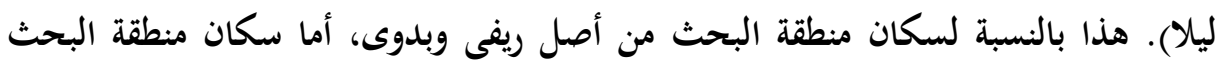

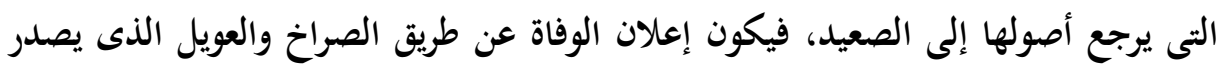

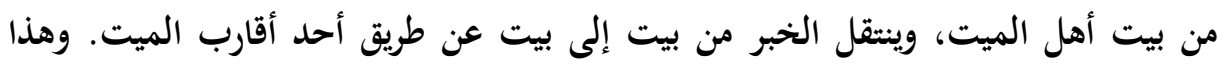

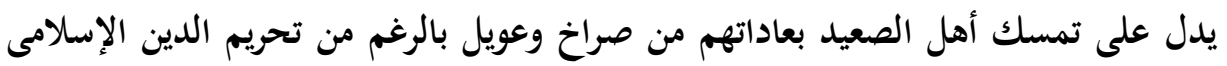

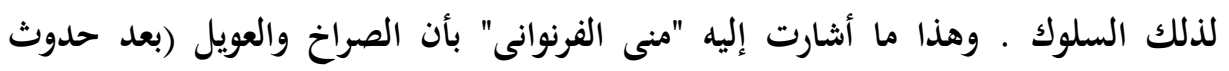

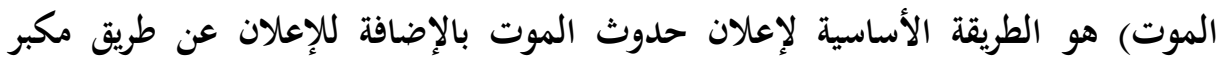

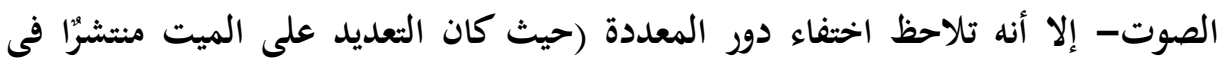

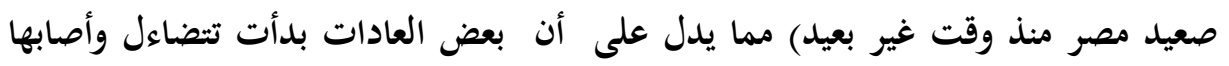

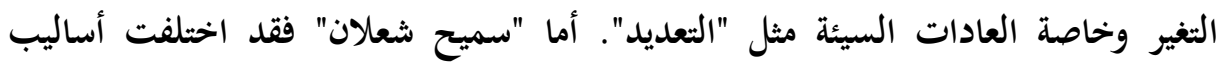
إعلان الوفاة فى دراسته، فقد أشار إلى تعدد أساليب الإعلان عن الوفاة ( صراخ النساء

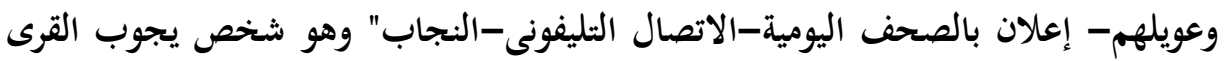
المختلفة ويخبرهم بالوفاة").

ولعل الاختلاف فى بعض التفاصيل التى يتم بها الإعلان قد تشير إلى بعض السمات

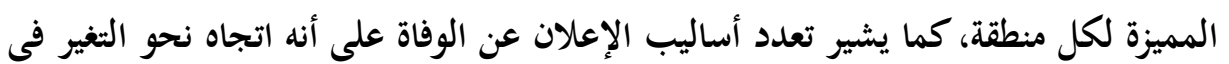

$$
\text { كثير من المجتمعات المصرية. }
$$

بعد حدوث الوفاة والإعلان عنها يجهز منزل المتوفى لاستقبال المعزين ويفرش

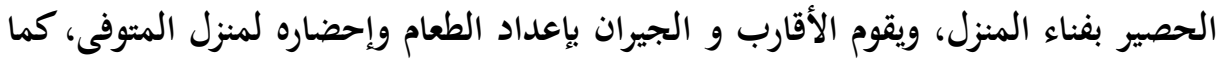
يجهز القبر من قبل بعض شباب القرية، حوالى ثلاثة أو أربعة أفراد تتوافر فيهم الخبرة والقدرة

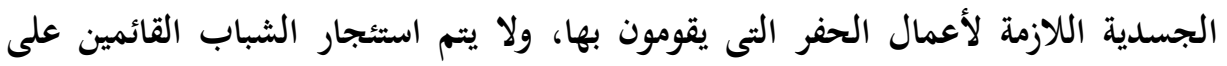

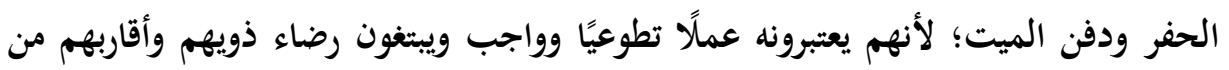

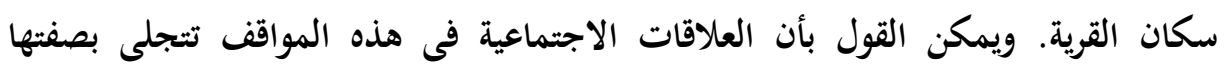
التضامنية، وتظهر فى أعظم صورها فى أمور تجهيز الميت، وهو أمر يسهم فى المزيد من الترابط والمشاركة الاجتماعية. 
وجدير بالذكر أن أهل الميت يحرصون على أن يكون تجهيز الميت من ماله

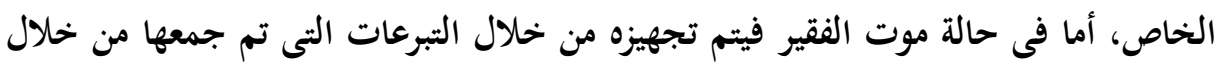

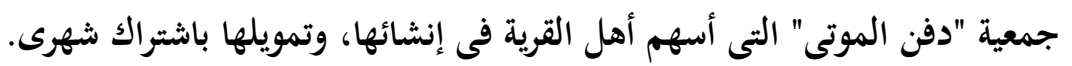

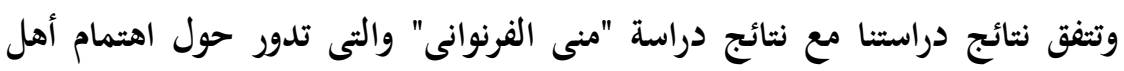
الميت بالإسراع فى تجهيزه من أموال الميت، وفى حالة عدم الاستطاعة تقوم الجمعية بتزويد أهل الميت بالنعش الذى يحمل فيه، وكذلك الكفن.

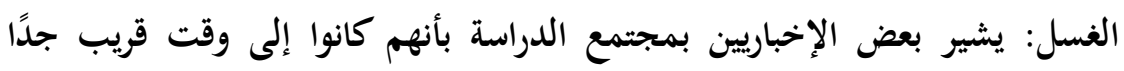

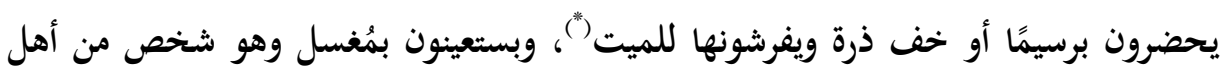

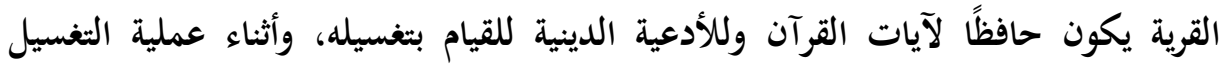
يرتدى فى يديه كيسا للوضوء وآخر للغسيل حتى لا تلمس يديه الجثة، وفي حالة عدم وجوده

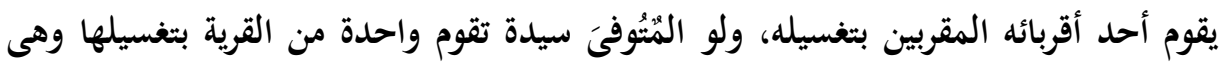

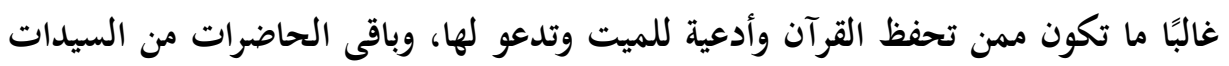
يرددون وراءها الأدعية. ويوضأ المتوفى وضوءًا كأنه سيصلى، وبعد الوضوء يُمنع تقبيل المتوفى. ويتم ربط الرباط من أعلى الرأس ورباط في منطقة الوسط ورباط يربط الرجلين معا.

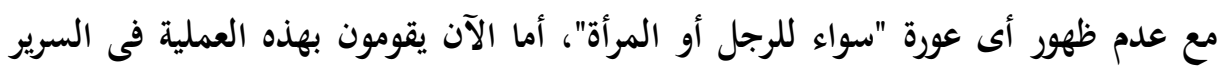

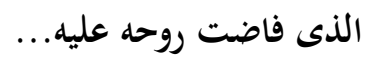

يُحضر للغسل ليفة و صابونة و عطر، ويوضع عطر في الماء الذي يُغُسل

به المتوفي، وقبل الغسل توضع الحناء على جثة الميت ثم يتم الغسل ويكفن بخمسة

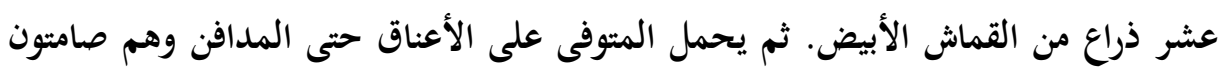

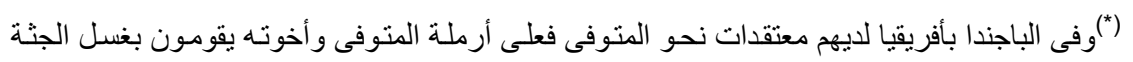

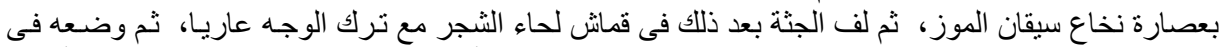

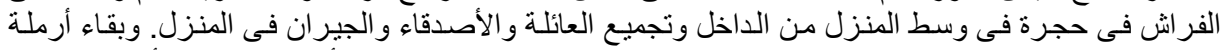

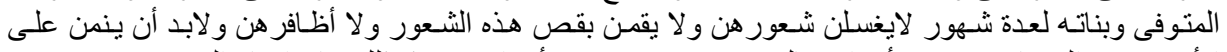

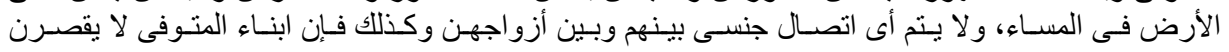
ومن بين المعتقدات التقليدية فى الباجندا بإفريقيا تقديم التضحيات والقر ابين للميت وبناء كوخ صغير فى المى شعور هن.

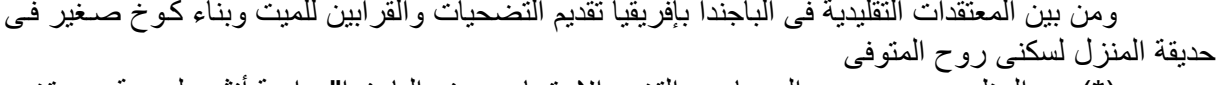

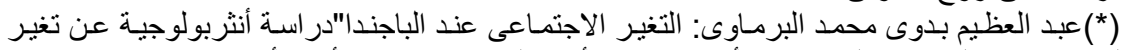

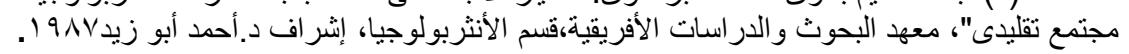


ولا تذهب النساء معهم، وبعد الدفن تقرأ للمثوفى الصمدية أحدعشر مرة، ثم الفاتحة والدعاء

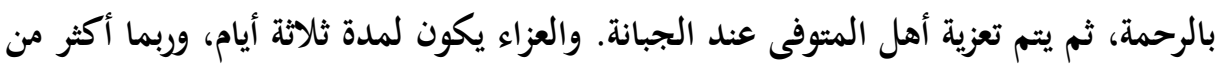
هذه المدة عند البعض، بينما كانت قى الزمن الماضى تمتد إلى سنة كاملة.

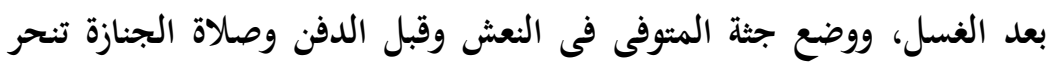
الذبيحة ويطلقون عليها "الونيسة" عند خروج الميت من داره، وذلك أمام النعش ويطعم منها

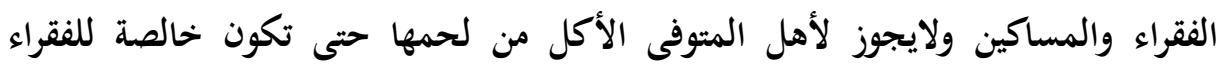
والمساكين، اعتقادا أن هذه الذبيحة تؤنس روح الميت فى قبره وثواب توزيع لحتئ لحمها يكون

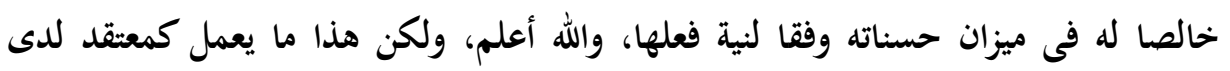

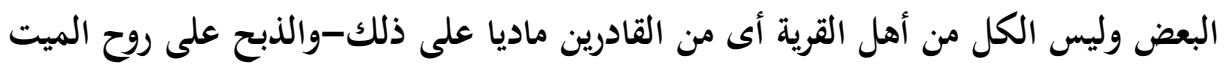

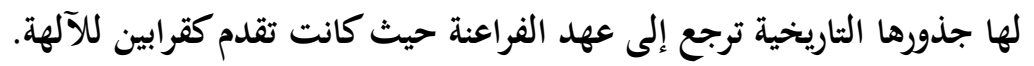
وقبل الدفن تتم صلاة الجنازة، ثم يحمل إلى المقابر، و يدفن فى اللحد (القبر)، ويتم

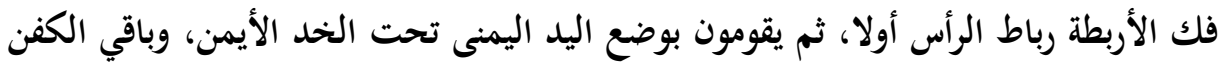

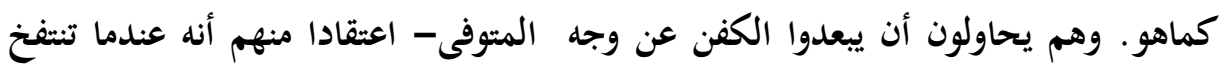
جثة المتوفى ويأتى الكفن على وجهه، يؤدى ذلك إلى أن يأخذ الكفن باقى العائلة وراءه - ثم

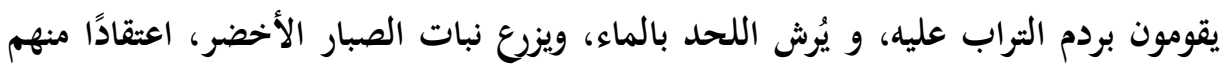

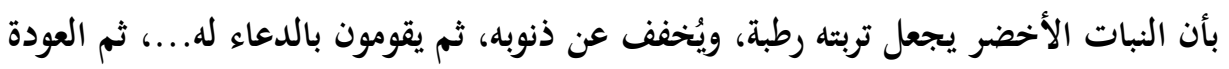

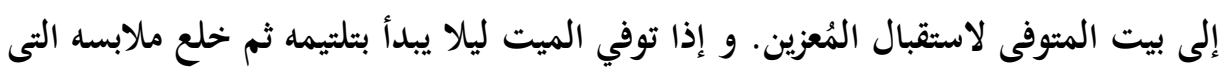

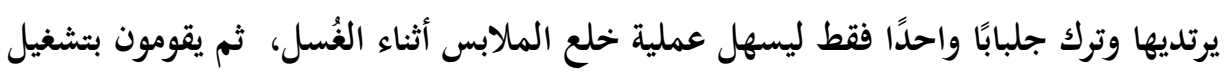

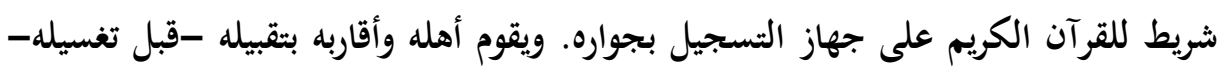
بقبلة الوداع · مريك. نجد أن هذه العادات المرتبطة بطقوس الوفاة لها صفة الثبات والاستمرار فى الثلاث

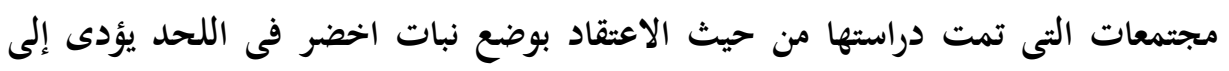

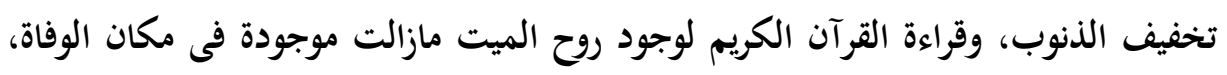
وهى تدل على إيمان المصريين بوجود حياة أخرى، وإعداد الروح لوجودها الجديد والإندماج

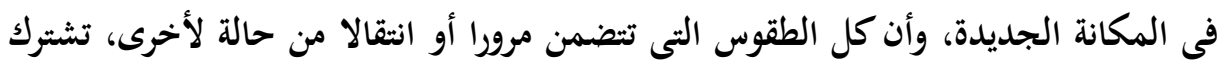


فى بناء واحد تحدده الوظيفة الضرورية للانفصال عن مكانة واحدة، وتدل هذه الوظيفة على الى

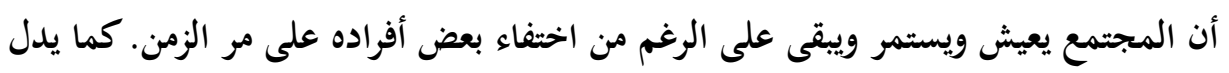
ذلك على عمق التدين لدى الشخصية المصرية وإيمانها بوجود حياة أخرى.

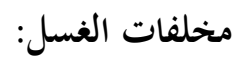

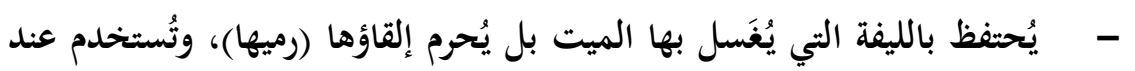

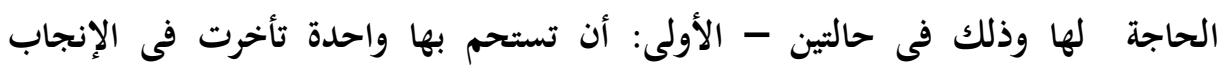

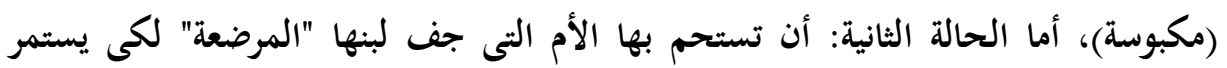
اللبن فى إدراره مرة ثانية، وتفك كبستهما على حد قولهم.

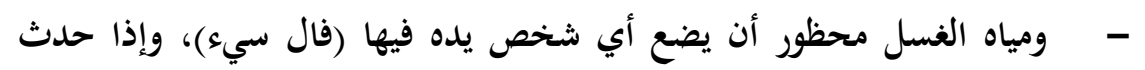

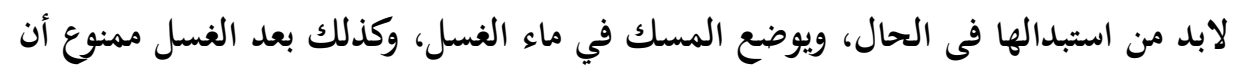

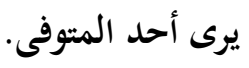
- - يَحظُر الاستغناء عن سترة المتوفي التى كان يرتديها قبل الغُسل، فيقومون بتقسيمها وتوزيعها على أبناء المتوفى للذكرى.

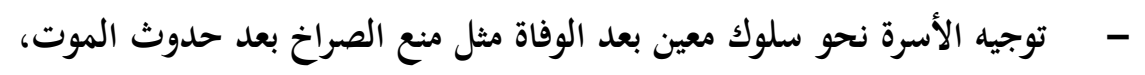

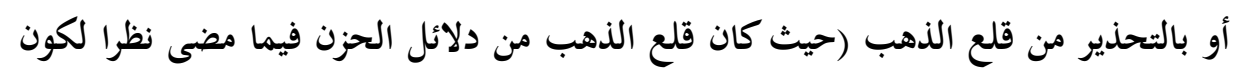
ارتدائه يعد من أمور التزين).

- وتنفق نتائج هذا البحث مع نتائج دراسة "منى الفرنوانى"، و"سميح شعلان".

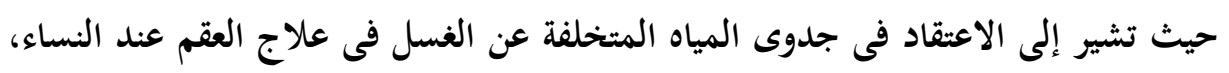

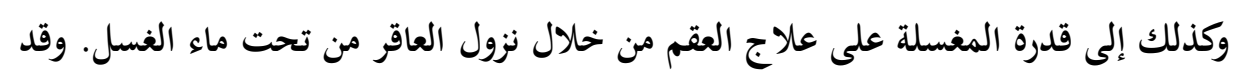

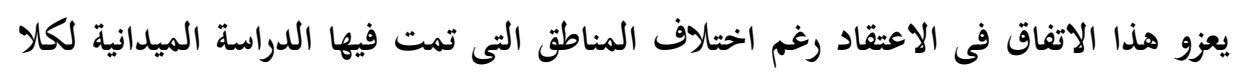

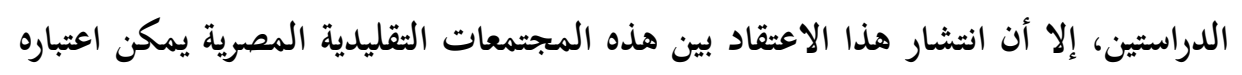

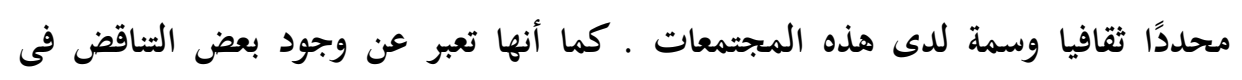

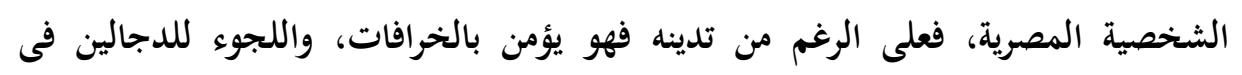

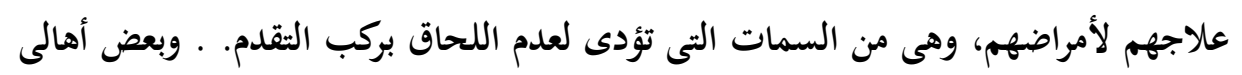

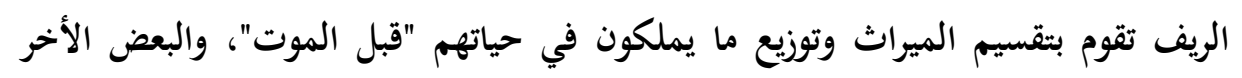


يقسم أملاكه" بعد الوفاة" بالنسبة للأهالي الذين من أصل "ريفي" يقسم الميراث حسب

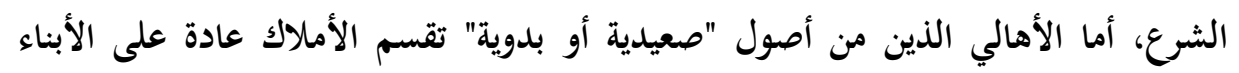

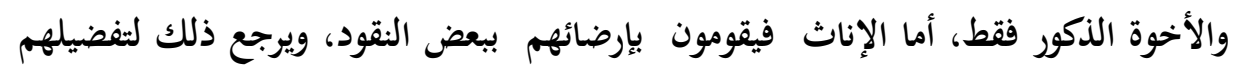

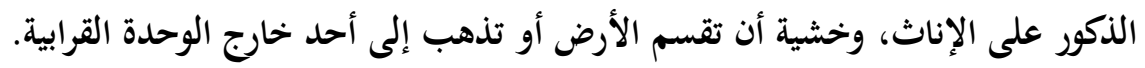

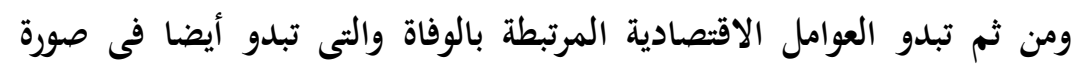
التهادى والتبادل الذى يتخذ شكل إخراج صوانى الطعام أيام العزاء من منازل الأهل والجيران التهان لمساعدة أهل المتوفى وللتخفيف عنهم. وتعكس تلك العوامل والرموز الاقتصادية ملامح شعائر ومرحلة الإندماج، فهى تهدف

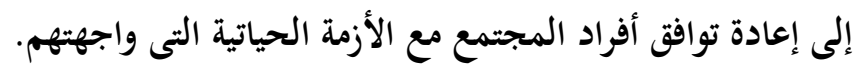

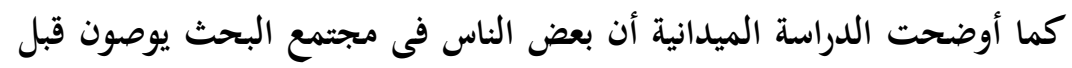

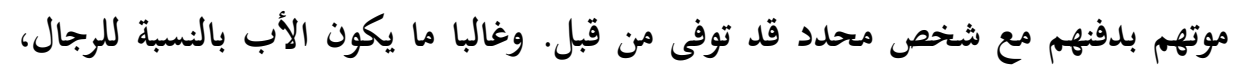

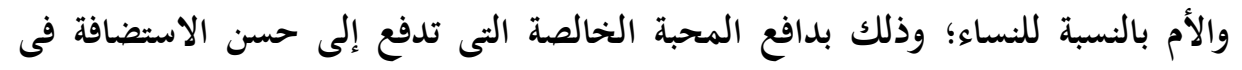

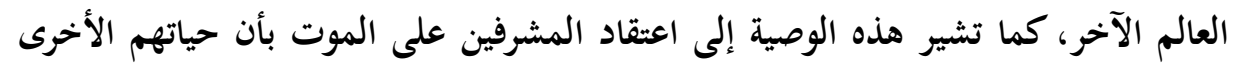
ستكون على شاكلة الحياة الأولى من العلاقات وطيب المكان.

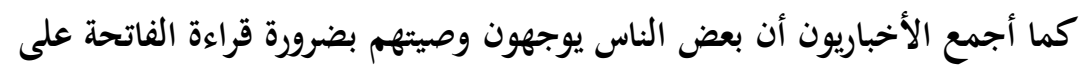

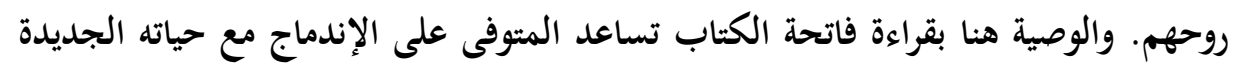
داخل القبر حيث لا ظلام ولا عذاب.

وحرص المحتضر على أن يوصى ببعض الوصايا للمقربين إليه قبل موته، فى

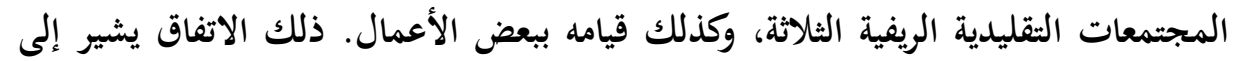

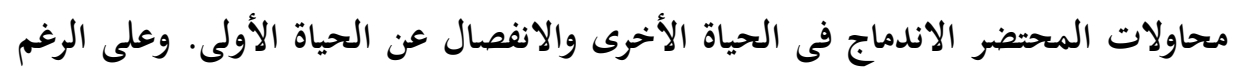

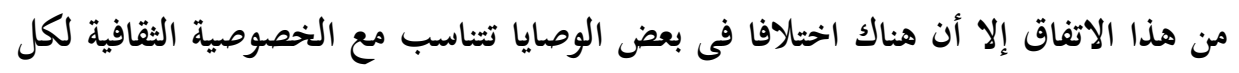
منطقة.

ومساعدة المتوفى على الرحيل والانتقال إلى العالم الآخر ترتبط هذه فى مجتمع

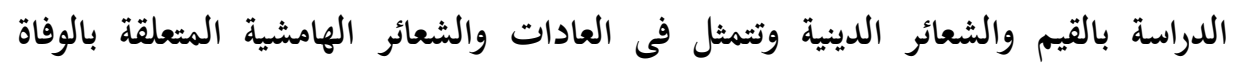


كتسهيل طلوع الروح، وتلاوة الشهادة من الحاضرين، والممارسات التى تتم بعد وفاة المتوفى

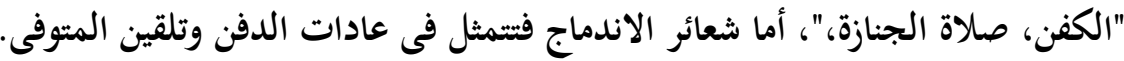
الديون: فى حالة وجود ديون على الميت يتم سدادها قبل الذهاب به إلى المقابر،

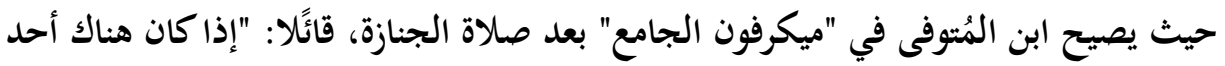

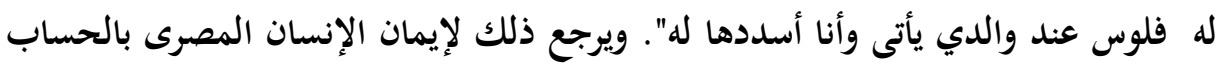

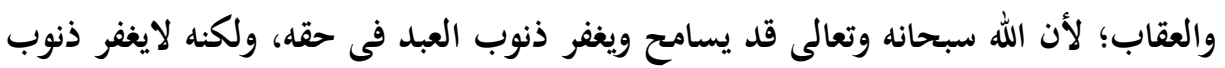
العباد لبعضهم البعض قبل أن يسامحوا هم أنفسهم بعضهم البعض، ولذلك يحرص أهل دهر

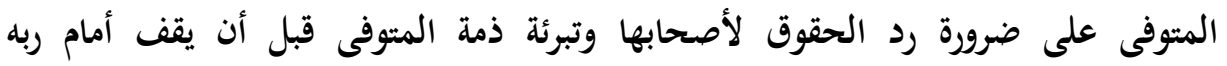
للحساب. مدة الحداد :أهل الصعيد يستمرون في الحداد عاما كاملا، أما الريفيون و أهل البدو

$$
\text { أقصى مدة حداد لهم أربعين يوما. }
$$

"وقد أخبرتنا إحدى الإخباريات إنه منذ وقت غير بونا بعيد كانت النساء عند العزاء

تقمن بالصراخ والعويل قبل الدخول إلى بيت المتوفى ونحملن فى أيديهن عصى قصيرة من

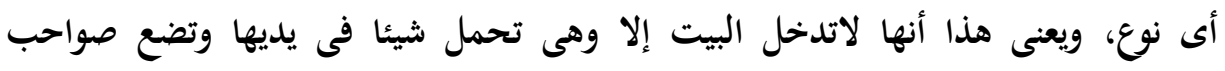

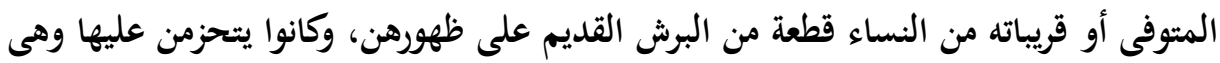

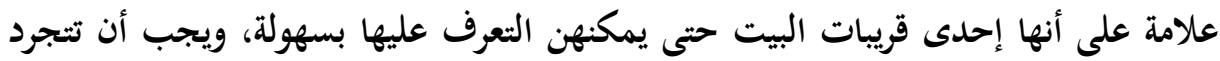
النسوة من الحلى أثناء التعزية كما أن قريبات المتوفى لا يلبسن الذهب لمدة أرئي أربعين يوما، كما يقمن بتعرية رؤوسهن وتحزيم أنفسهن ويضعن الطين أو الرماد على رؤسهن ويأتى الرجال مسرعين ويقومون بالتعزية."

$$
\text { وصالثا- الدفن: }
$$

هى قطعة أرض فضاء في صحراء بعيدة تقع قى شرق القرية بحوالى أربعة عشر كيلو

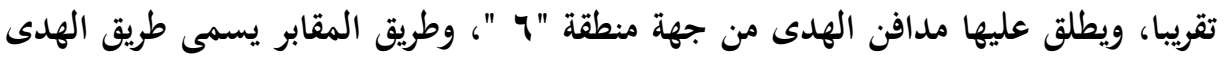

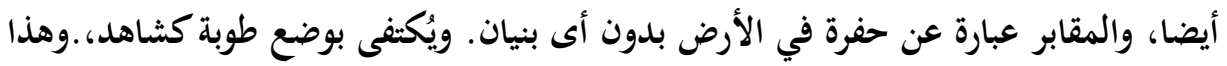

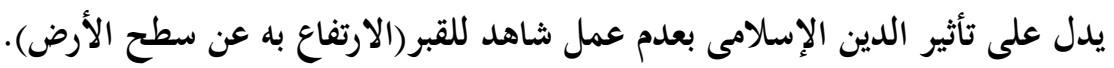


- - عادة يذهب الشباب إلى المدافن لحفر اللحد، حيث لا توجد مقابر مشيدة،

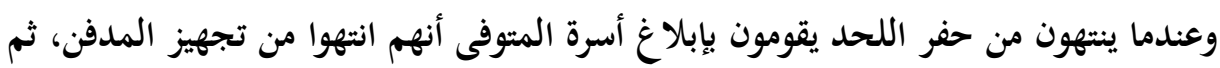

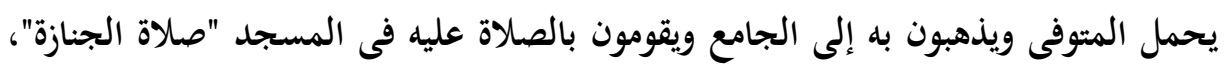

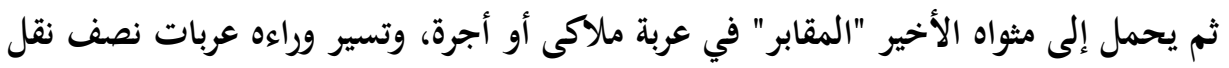

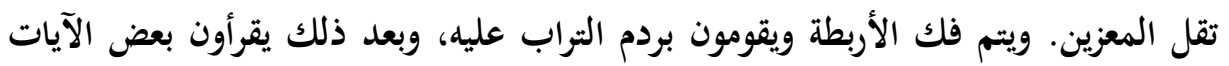
القرآنية و الفاتحة ويلقنوه الشهادة، ثم يعودون إلى بيت المتوفي لإنو لاستقبال المُعزين. -

- - مالعزاء فى المقابر يكون "مقصَّرًا" على من يأتون من أماكن بعيدة ومن القرى

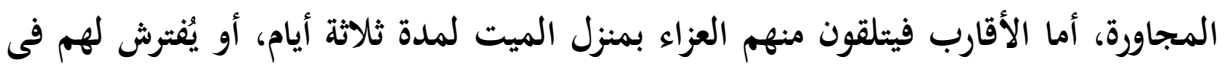
مركز الشباب فى أول يوم فقط من وفاة الميت، واليومان الثانى والثالث بمنزل المتوفى. لهن.

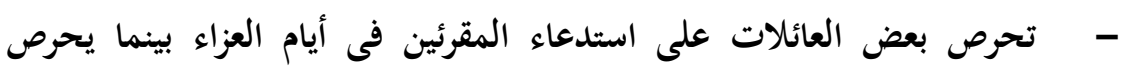

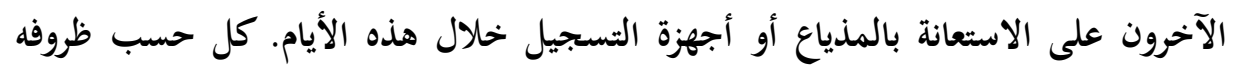

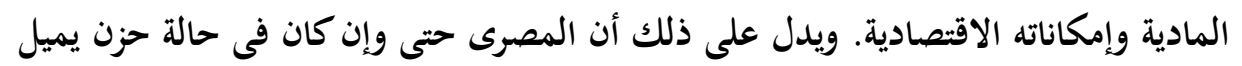
إلى التفاخر والتباهى بقدرته المالية على إحضار أغلى المقرئين.

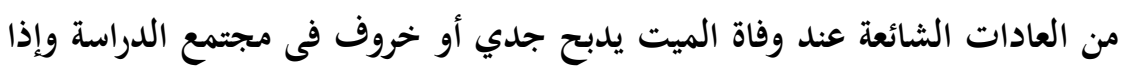
لم يكن عند أهل المتوفي ما يذبحونه، يأخذ الأضحية من جاره.

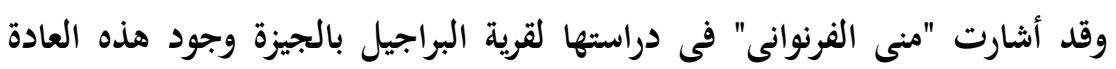

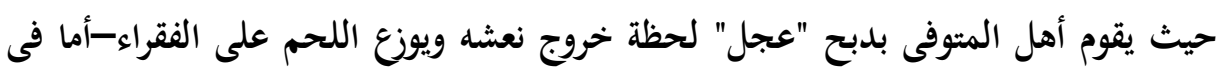

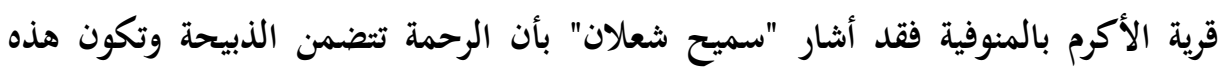

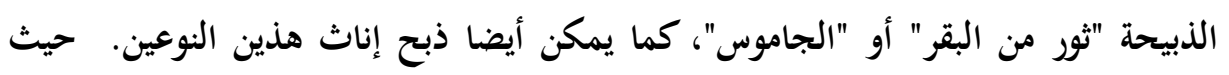

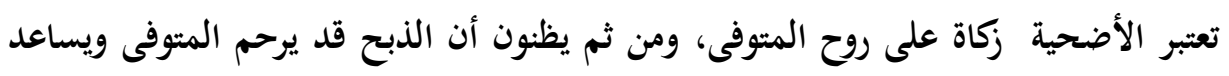
على الغفران له، وقربانا لتخفيف ذنوب الميت، ويجمع الإخباريون على استمرار هذا الاتجاه

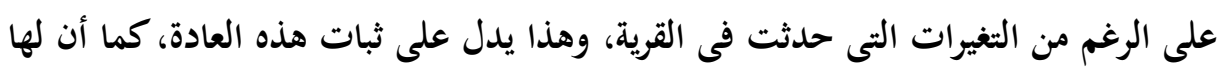

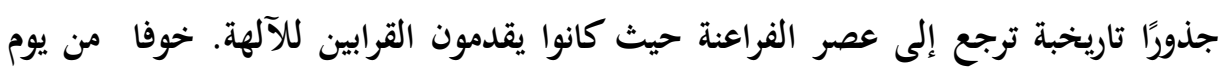


الحساب، كما تعبر عن صفة أصيلة فى المجتمعات الريفية التقليدية وفى الشخصية المصرية

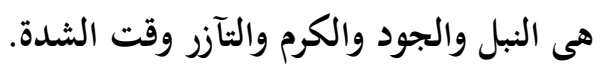


بعض المعتقدات المرتبطة بالقبر:

تدور فى مجتمع البحث بعض المعتقدات المرتبطة بالقبر مثل علاج العواقر والأطفال

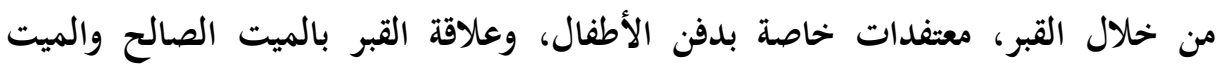
الطالح:

هناك اعتقاد سائد بأن الأم التى تموت ويدفن معها مولودها يكون سببا فى دخولها الجنة، ويكون سببا فى رحمة كل الموتى.

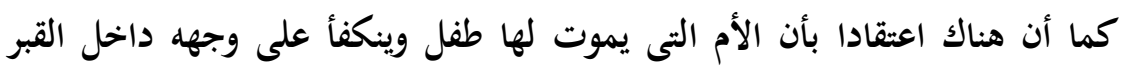

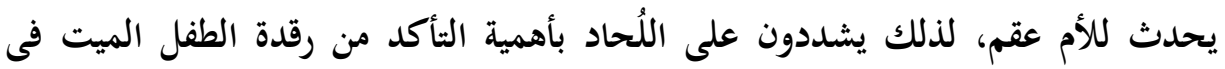
القبر .

ويعتقدون أن الميت الصالح يكون قبره منور، ووزنه خفيف بالنعش ويجرى بالجنازة، وعكس الحال إذا كان الميت طالحا . لقد أشارت كل " منى الفرنوانى"، و "سميح شعلان" إلى انتشار بعض تلك المعتقدات

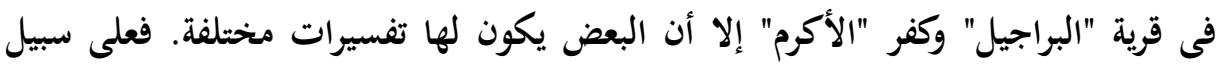

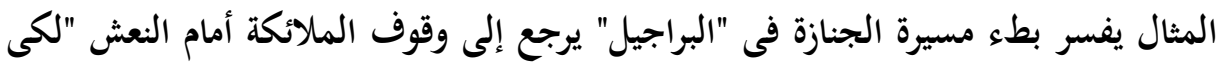

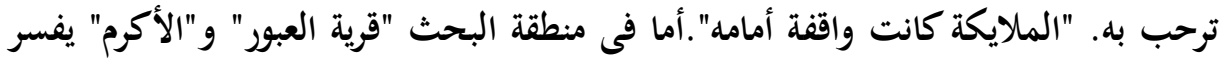
هذا البطء بأن الميت عمله غير طيب، وخائف من الحساب، وهذا يعطى مؤشرًا لإيمان المصرى بالغيبيات والروحانيات والخرافات.

$$
\text { توزيع الميراث: }
$$

يقوم بعض أهالى الريف بتقسيم وتوزيع ماتملك في حياتها "قبل الموت" و البعض الأخر يقسمون أملاكهم "بعد الوفاة". بالنسة للأهالي الذين من أصل "ريفي" يقسم الميراث

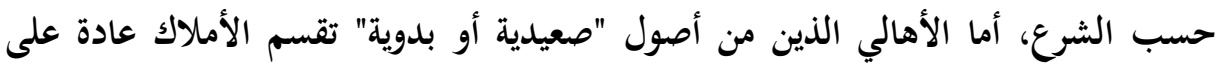

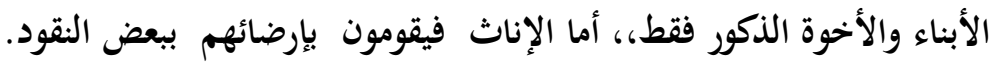

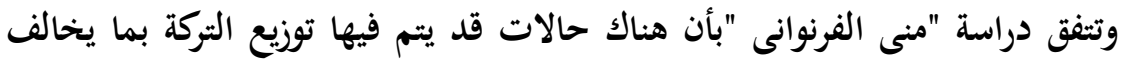
الشرع، قد تكون بزيادة نصيب الذكور عن الإناث؛ وذلك خوفا على الميراث من ضياعه بين يدى أزواجهن، أو أن تقسم الأرض وتذهب إده ندي إلى أحد خارج الوحدة القرابية، أو لتفضيلهم 
الذكور عن الإناث أو قد تكون بحرمان أحد الأبناء بسبب عصيانه من نصيبه الشرعى نظير

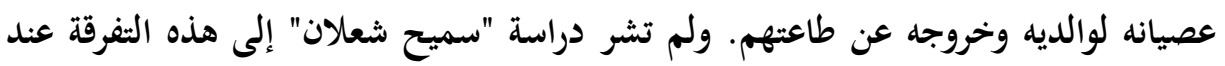
توزيع التركة مما يدل على أنها ليست سمة أصيلة فى المجتمعات التقليدية الريفية.

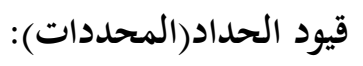

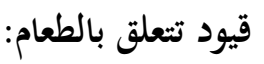

يُحَرم أهل الميت على أنفسهم فى فترة الحداد طهى المحاشى أو الكحك

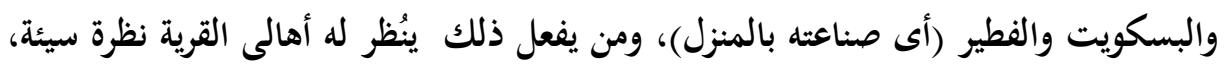

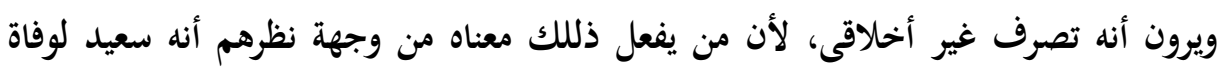

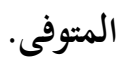
قيود تتعلق بالملبس

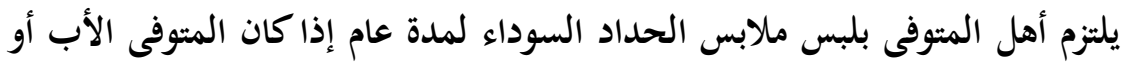

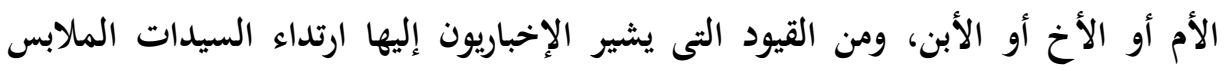

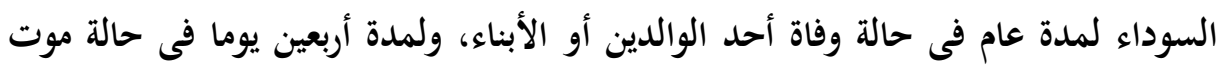

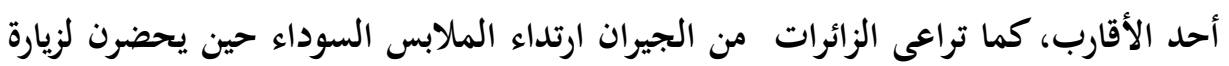

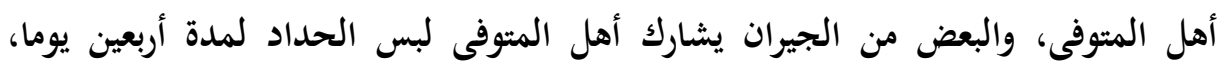
والرجال يرتدون الملابس الداكنة لمدة ثلاثة أيام.

$$
\text { قيود على العلاقات الجنسية }
$$

المرأة التى يموت عنها والدها أو والدتها أو ابنها يحترم الزوج مشاعرها وحزنها

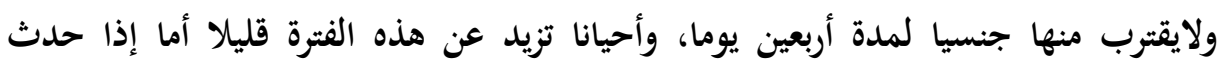

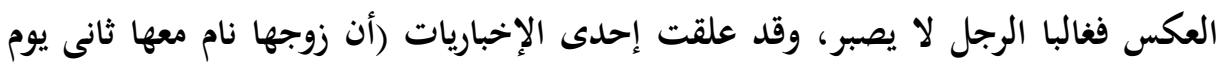

$$
\text { دفن أمه قائلا الحى أبقى من الميت). }
$$

- - يحظر على أهل المتوفى تشغيل التلفاز أوإقامة أو حضور أى فرح لمدة تتراوح

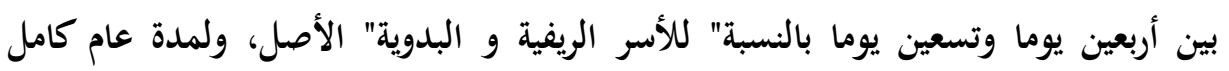

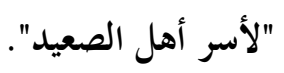




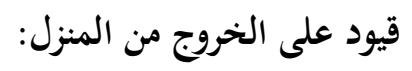

المرأة المتزوجة ويموت عنها زوجها لاتخرج من مسكنها لمدة أربعة شهور وعشرة أيام حداد على زوجها وطبقا لأحكام الشريعة الإسلامية إلا فى الضرورة القصوى( إعلان

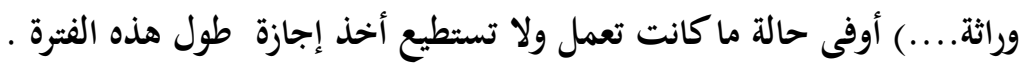

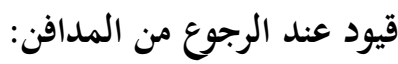

- لايدخل "الرجال" على ذويهم بعد رجوعهم من المقابر بدون: غسل وجوههم وخلع أحذيتهم -والتى قد تحمل بداخلها بعض تراب المدافن- لأنهم يعتبرون ذلك ( فألاً سينًا).

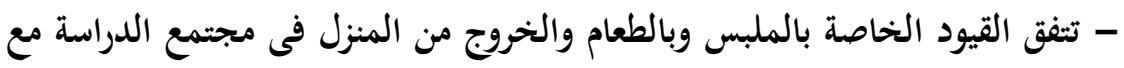

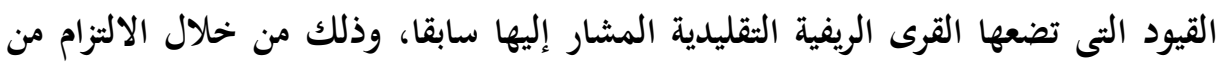

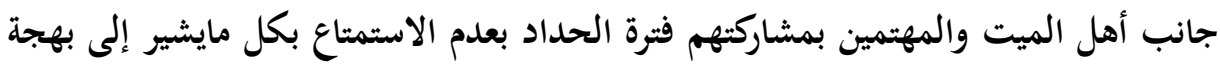

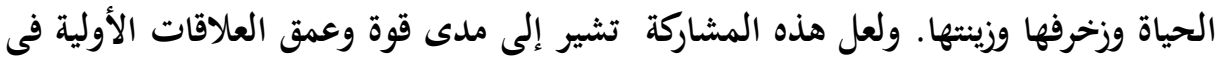

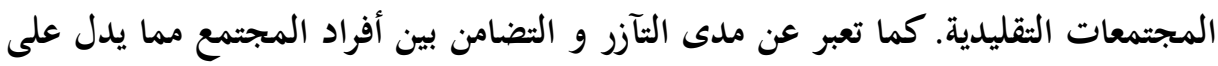
أنها سمة أساسية للشخصية المصرية. مناسبات زيارة القبور:

زيارة القبور: يقوم أقارب المتوفى بزيارة قبر الميت بعد أسبوع من دفنه فى أيام

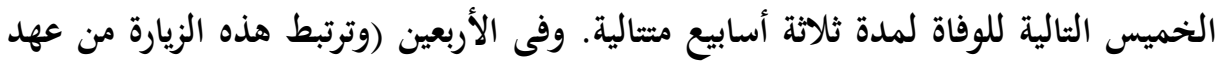

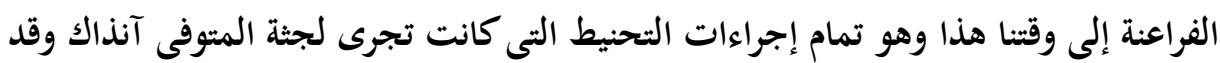
توارثها المصريون وتتم فيه زيارة قبر المتوفى).

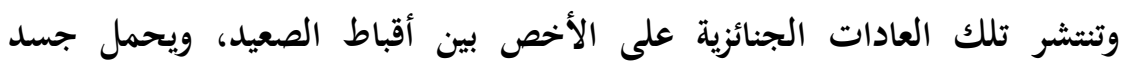

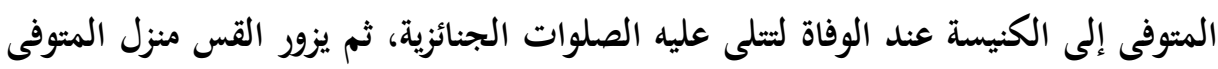

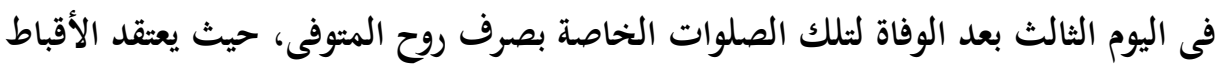

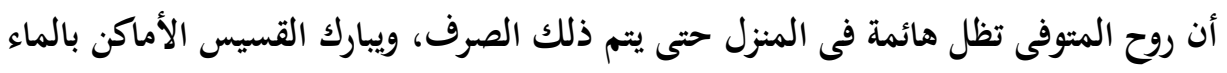
المضاف إليه الملح وغصن أخضر وبعض البقدونس أو البرسيم ويرش بها ملابس المتوفى البهى

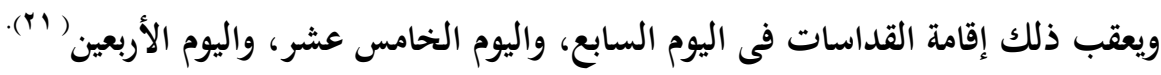


المناسبات الدورية لزيارة القبور: يتم الذهاب لزيارة المقابر فى الأعياد (طلعة العيدين

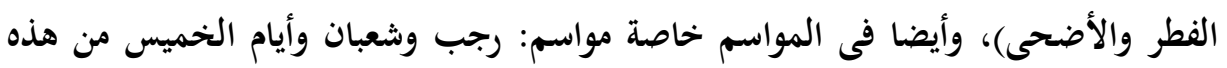
الأشهر والتى تقوم بها السيدات لتدل على حرص أهل المتوفى بالذهاب إلى زيارة المقابر فى لى

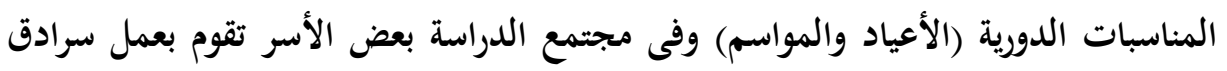

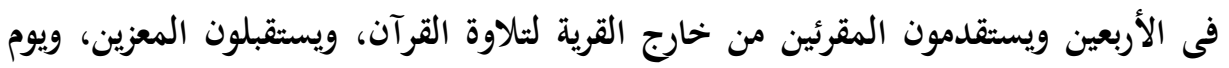

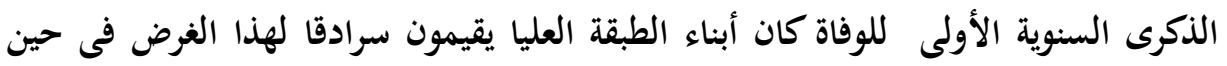

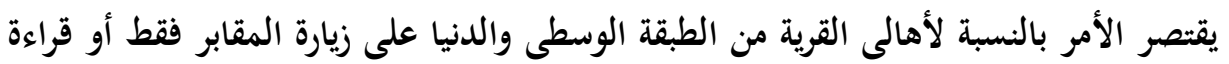

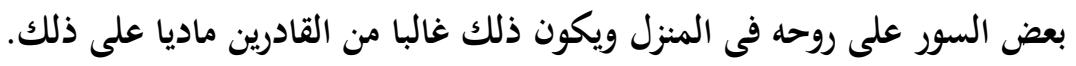

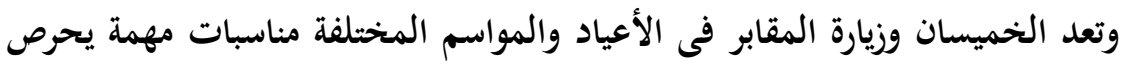

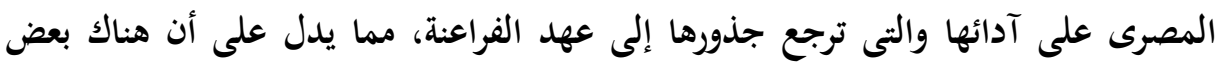

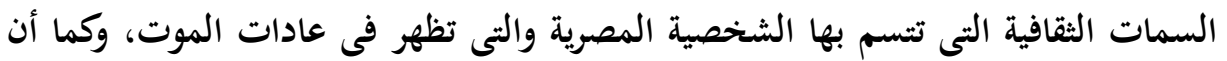
استمرار هذه العادات والممارسات تظهر المعتقدات التى تدور حول وجود روح الميت فى في لهي

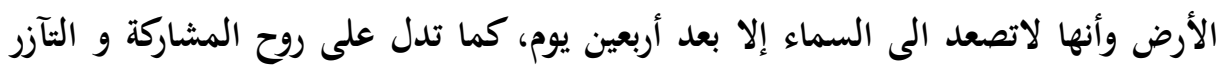

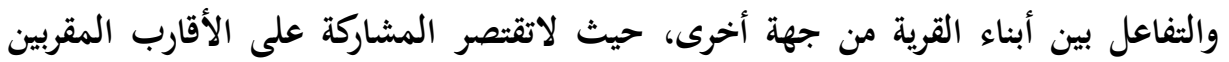

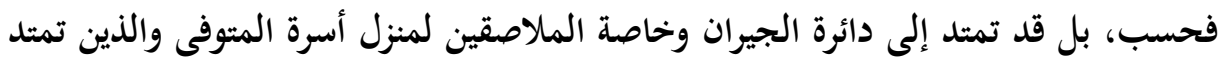
جيرتهم إلى فترة زمنية طويلة، حيث تعمل (الجيرة) على تدعيم الروابط بين الأسر، وتسود

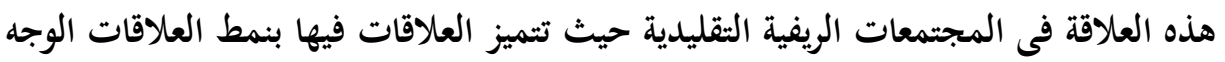
للوجه.

وتتفق نتائج دراستنا مع نتائج الدراستين المشار إليهما حول وجود قيود للحداد على

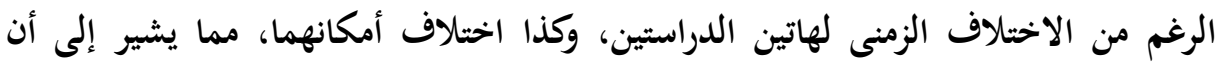
الحزن على الميت يدفع الأحياء إلى تحريم بعض المتع التى حرم منها المتوفى. وتظهر

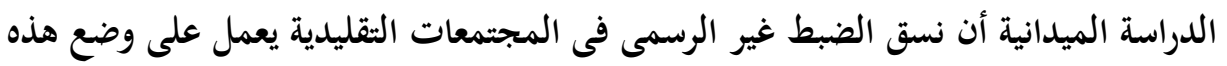

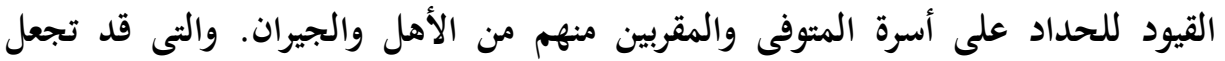

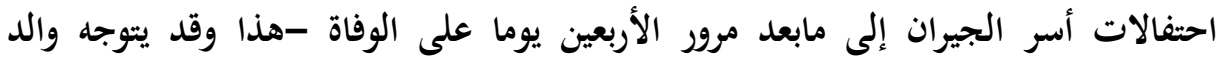
العروس إلى منزل أسرة المتوفى "صاحب الجرح" لإستئذانه فى إقامة فرح ولكى يثبت الجار الجى 
عدم مضايقته يتوجه لحضور الاحتفال و لوكان ذلك لدقائق معدودة-ولعل ذلك يشير إلى مدى رقة المشاعر وعمق التآزر بين أفراد المجتمع المصرى فى المجتمعات التقليدية ولعل ولتهل

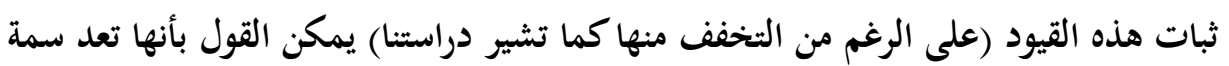
من سمات الشخصية المصرية.

وتتفق نتائج دراستنا مع نتائج دراسة "منى الفرنوانى" و "سميح شعلان"أن بعض التص العادات والطقوس المرتبطة بالموت تتصف بالدينامية تبعا لما تفرضه عليها طبيعة الوظيفة

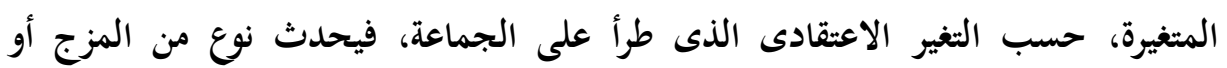

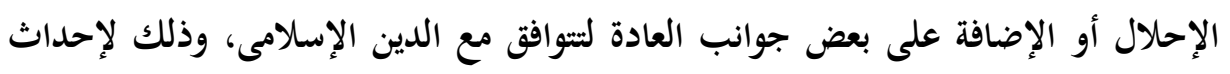

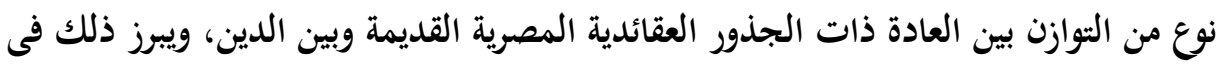
مظاهر الحداد من البكاء والتخلى عن الزينة ولبس الملابس السوداء لمدد طويلة- ماعدا سكان أهل مجتمع البحث والذين ترجع أصولهم إلى صعيد مصر كما سبق الذكر، وأيضا

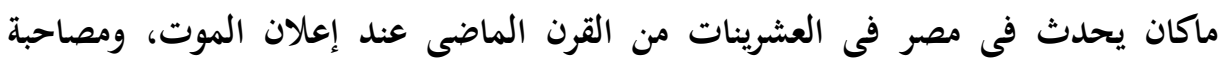

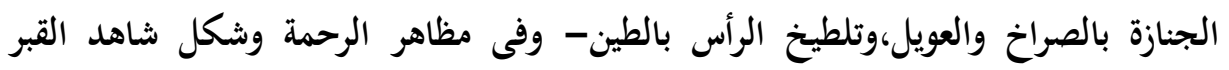
الخاص بالرجال وتلقين الميت. نتائج الدراسة الميدانية

بعد أن تعرضت الدراسة الميدانية للعادات والطقوس المصاحبة لوقوع الوفاة فى مجتمع محدد بحدود مكانية وزمانية، ومن خحلال جوانب الاتفاق والاختلاف بين نيله نتائج دراستنا، ونتائج دراسة كل من "منى الفرنوانى"، ودراسة "سميح شعلان" فى مجتمعان ريفيان

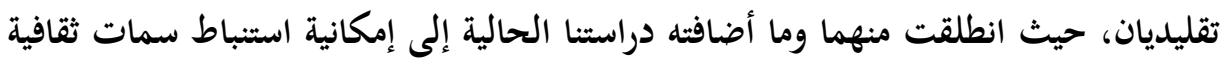

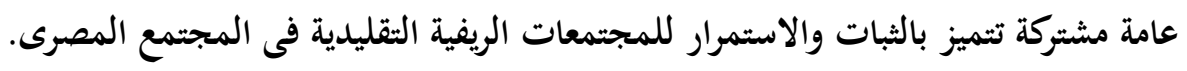

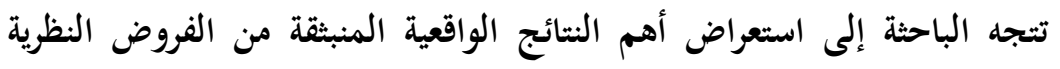

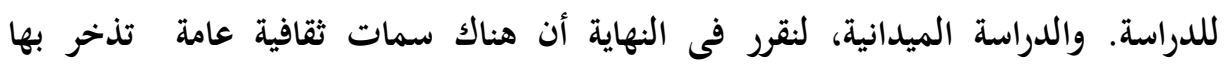
المجتمعات الريفية التقليدية، وعن الشخصية المصرية واضحة وممثلة فى الممارسات

$$
\text { والعادات المصاحبة لحالات الوفاة وهى :- }
$$


النضامن والتآزر الاجتماعى: تعكس عادات الوفاة مدى ما تتمتع به المجتمعات الريفية التقليدية من حب للتعاون والتضامن الاجتماعى، ويشكل التماسك الاجتماعى وطبيعة العلاقات الاجتماعية بين الأفراد أعراف لها أصول كقانون عام. أدت جميعا إلى وضع قيم ومعايير ثابتة بين أفراد الجماعة وشكلت إطارا مرجعيا لسلوكهم وآدابهم، وعبروا عن ذلك الك عند حدوث أزمات للبعض منهم، وخاصة وقت الشدائد وفى حالات الوفاة كإخراج صوانى

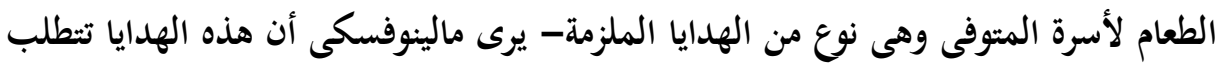
دفع مقابل مماثل لها تماما فى المناسبات المماثلة- كذلك مشاركتهم فى حضور شعائر

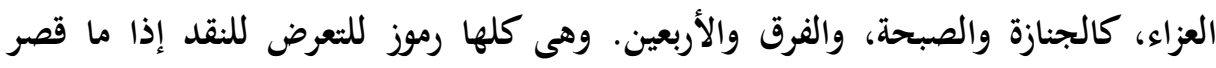

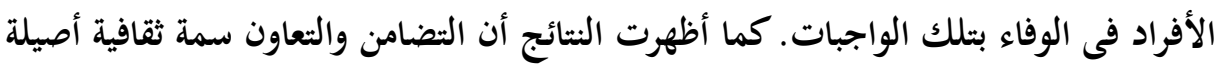
فى المجتمعات الريفية التقليدية ومن سمات الثخصية المصرية. - تقديس الموت: حرص المصرى على التعبير عن مدى حزنه وشعوره بقدسية الموت، حيث تنصف بعض العادات والطقوس المرتبطة بالموت بالثبات تبعا لما تفرضه عليها

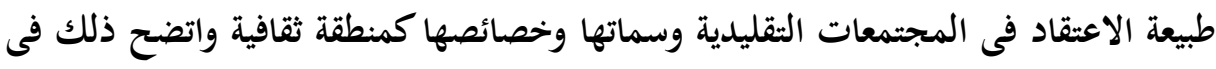
"مجتمع البحث"، وفى الدراسات السابقة المقارنة والتى أجريت فى الثمانينيات وأوائل التسعينيات، فضلا عن استمرار بعض قيود الحداد التي كانت تدعو إلى عدم طهى أوتحريم

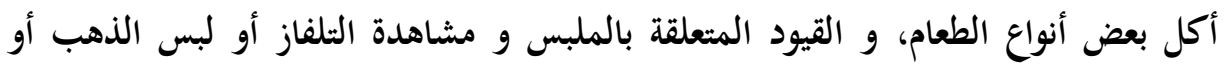
تجديد أو بناء في دار المتوفي، فضلاً عن القيود المتعلقة بإضاءة بيت المتوفي، والعلاقات الجنسية ونظافة أهل بيته. وقد لقيت هذه القيود درجات مثنفاوتة من الاستجابة من حيث الاستمرار والحذف حسب اقتناع ممارسيها بأهميتها في التعبير عن الحزن والحداد على مئى الميت، إلا أن الدراسة الميدانية تشير إلى الاتجاه نحو استمرار معظم تلك القيود.كما أن سمة تقديس الموت لها بعد زمنى يرجع إلى عادات الموت وطقوسه عند المصريين القدماء. الحزن: "مسحة الحزن ظاهرة منتشرة فى المجتمعات الريفية التقليدية ويتضح ذلك ذلك إلك فى الأساليب التى تتبع فى مناسبات الوفاة ومظاهره، تبدو كما لو كانت حزنا إجباريا. يفرضه

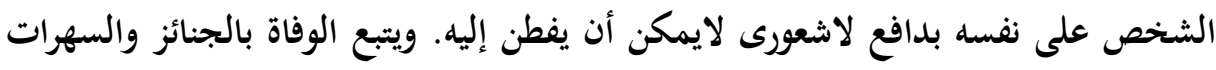

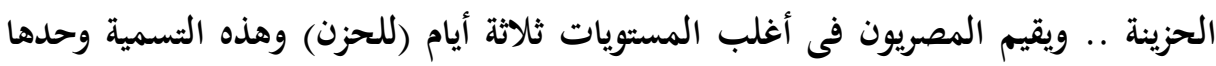


كفيلة بتوضيح المكنونات اللاشعورية التى تهيمن على الموقف وتفرضه فرضا على الإنسان

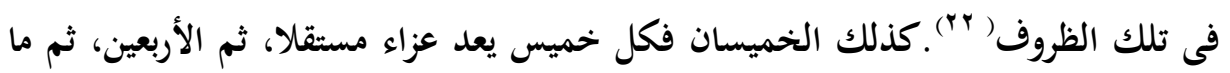

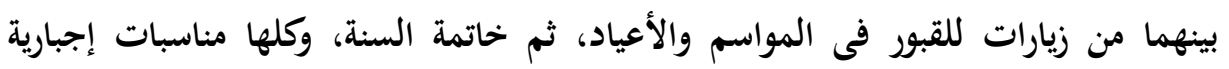
للحزن وزرف الدمع، كذلك تظهر رغبة عارمة فى الاتجاه إلى الحزن. والأسى فى الموال

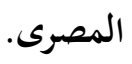

انفراد الشعب المصرى بابتداع أساليب خاصة يعبر بها عن حزنه من صراخ وعويل، مما خلق دور "المعددة" أو دور"الندابة "ودور "ضاربة الطار" وبقومون بدور التعزية وأثناء تشييع الجنازة وبعدها، وبعد الدفن. - التدين: ترتبط شعائر وعادات وتقاليد الوفاة بالقيم و الشعائر الدينية (وتظهر هذه الشعائر مدى تأثر الريفيين فى المجتمعات التقليدية بالدين، ومن أكثر السمات التئمرارية

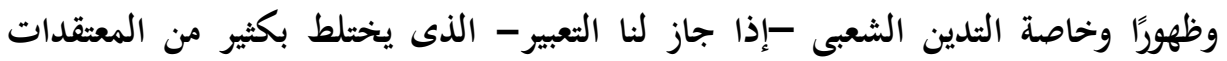

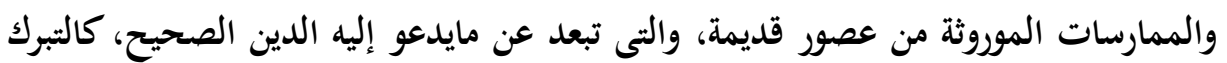

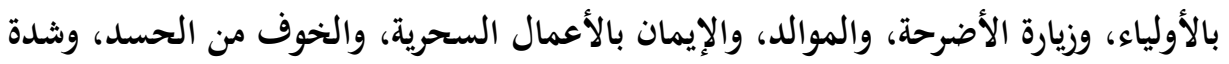

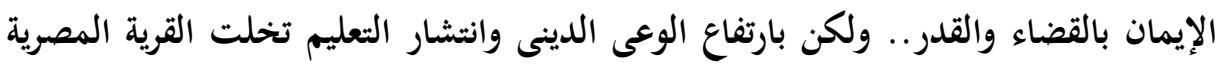
خاصة فيما يتعلق بسلوكيات النساء عن بعض الممارسات الخاطئة.

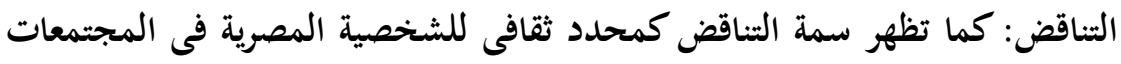
التقليدية، فنجد الإنسان المصرى يحزن ويبكى من صميم القلب ويشارك الآخرين أحزانهم

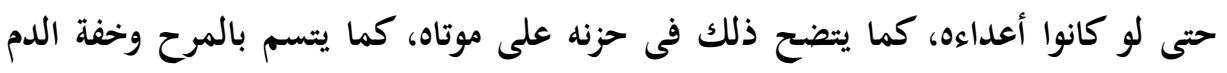
وإطلاق النكات حتى فى أشد أوقات المعاناة وأحلك الأزمات،

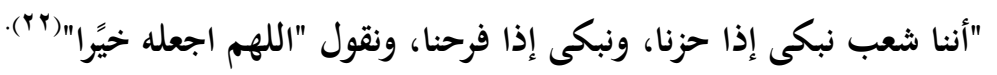

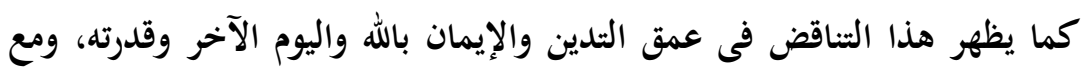

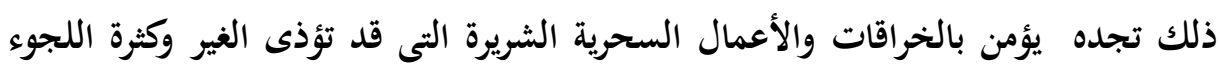

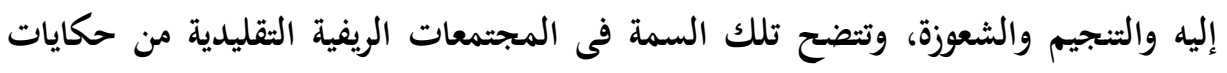

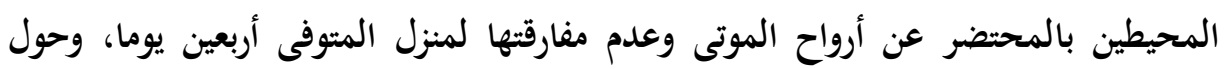

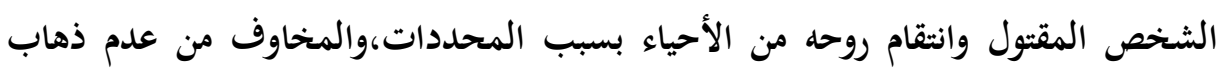


أهل المتوفى الثلاثة خميسان، واعتقادهم أن ماء الغُسل وسيلة لعلاج الكبس والعقم،

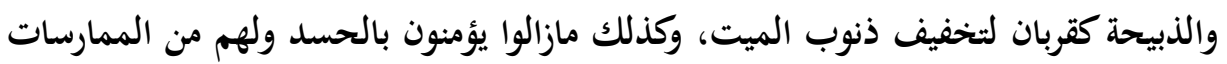
الخاصة لتلافى السحر والحسد. كما تجده فى كثير من الأوقات والمواقف شديد الصبر ضابطاً للنفس وفى نفس النس الوقت عندما يثور لايستطيع أن يوقفه أحد ولا تهدأ ثورته بسهولة. حسن الخلق: إن مأساة الوفاة تظهر حسن خلق المصرى في صفائه وسماحته ورقة مشاعره ومشاركته الوجدانية التى تعبر عن أصالة يصدر عنها نظام بنيانى للحياة، وتظهر هذه إنهاه

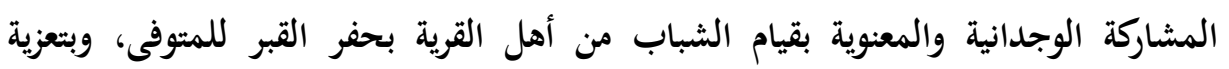

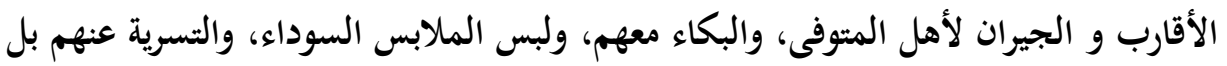

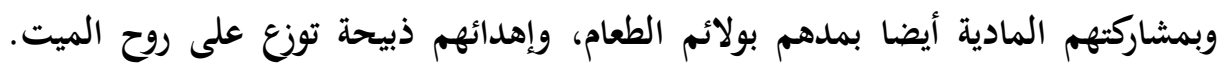

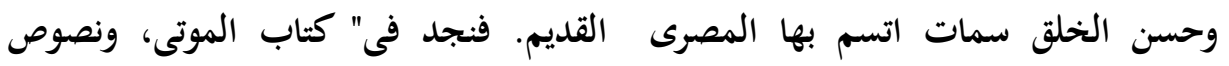

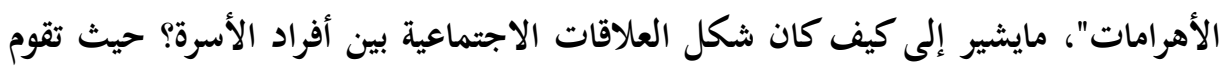

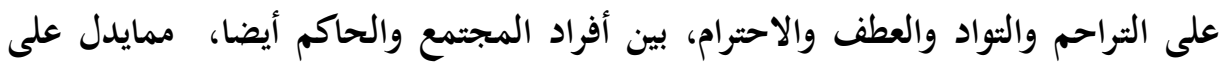
تمتع هذه السمات بالثبات والاستمرار. التفاخر والتباهى من عيوب الشخصية المصرية التفاخر والتباهى بأنفسهم إلى حد

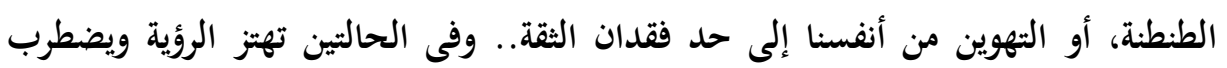

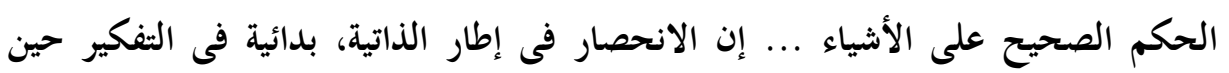

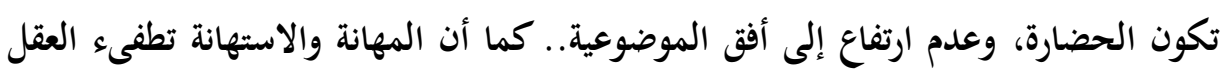

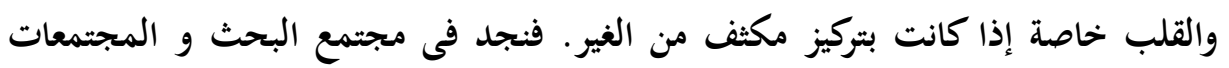

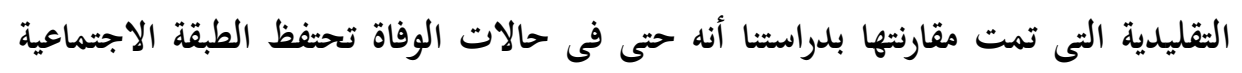

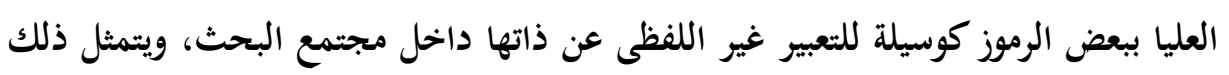

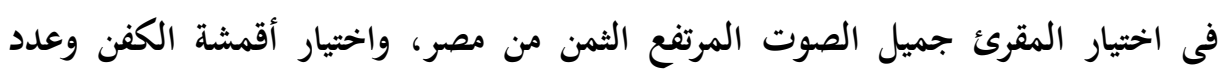
طبقاتها، ووضع غطاء مختلف على النعش، والتباهى بقدرتهم المالية.

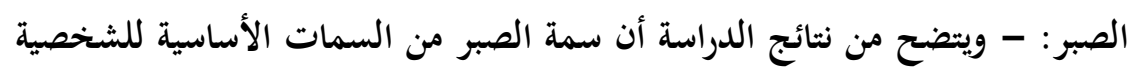
المصرية، فالفلاح المصرى صبور وصبره من النوع الفريد . وقد يرجع ذلك لطبيعة البيئة 
الإيكولوجية التى نشأ فيها المصرى، فمصر بلد زراعية والفلاح المصرى لكى يجنى ويحصد

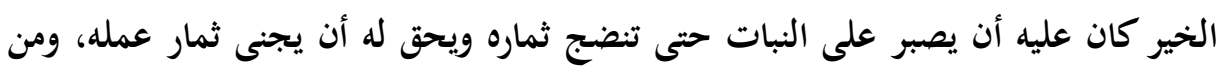

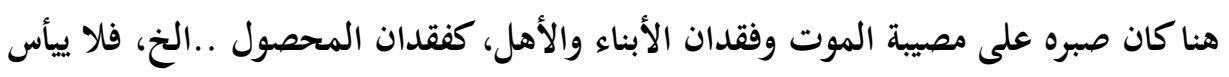

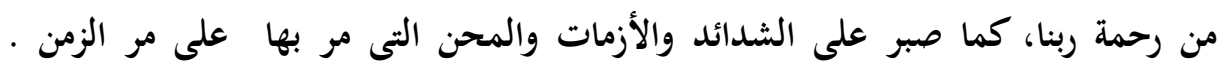

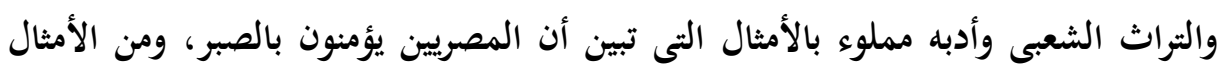

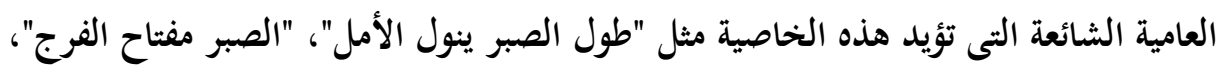

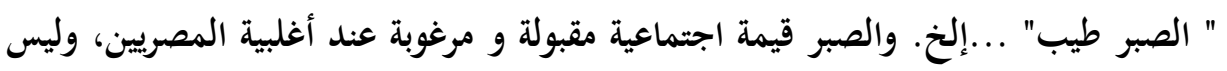

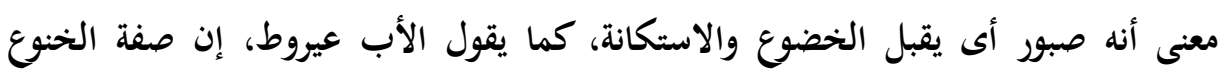

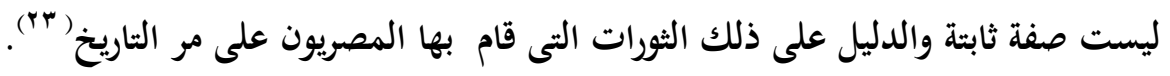
وقد أكد فريق بحث إعادة بناء الإنسان المصرى، أن الصبر نمط سلوك يتكرر

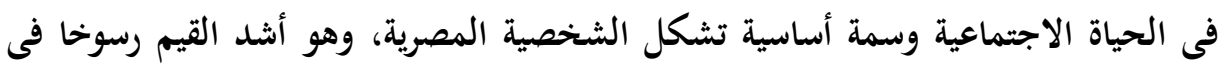

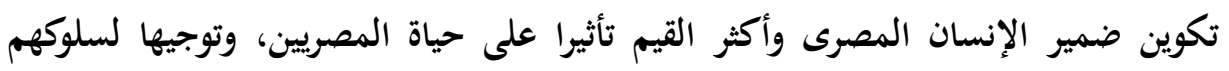
وعلاقاتهم وتصرفاته. والصبر كقيمة اجتماعية يعمل على تجانس الشعب المصرى الهيم حتى تصبح

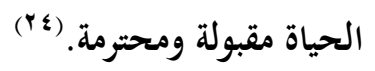

فالصبر خاصية من الخصائص القومية عند المصريين يقوم بوظيفة اجتماعية من

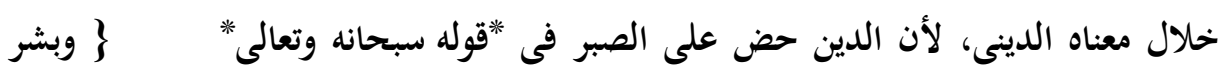

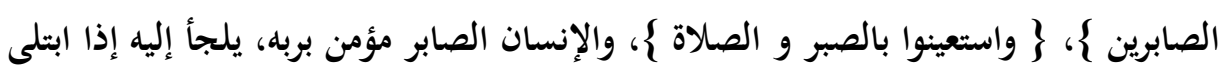
بفاجعة أو مصيبة مستعينا به. التواكل أو الاتكالية: يتسم الريفيون المصريون بالتواكل والاتكالية ويقول (إن شاءالله) ويعنى فى قرارة نفسه التخفف من العمل المقصود. إن هذه المشيئة ما هى إلا تأكيد للعزم

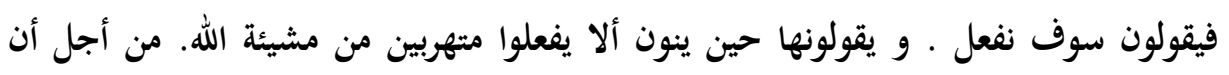
يستشعروا الراحة فى (ضمان) لحل مشاكلهم. فكثيرا لايفرقون بين التوكل والتواكل.

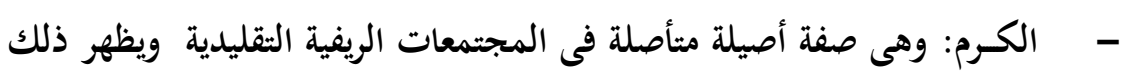

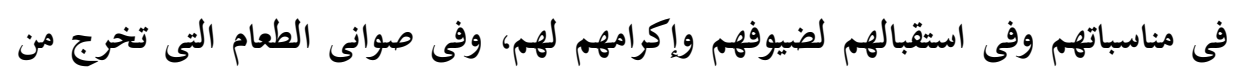


بيوت الأسر المختلفة لمشاركة أهل المتوفى، وفى إهداء الجيران أيضا لبعضهم البعض ذبيحة كل حسب ما تسمح به ظروفه الاقتصادية عند حدوث وفاة .

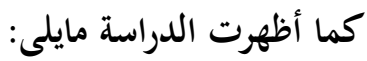
- - مأن بعض العادات والطقوس تتصف بثبات ممارستها مع جذورها المصرية القديمة. وذلك لقدرتها على آداء وظائف ثابتة، واستمرارها إلى وقتنا الحالى مع اندثار

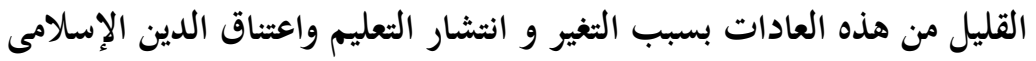

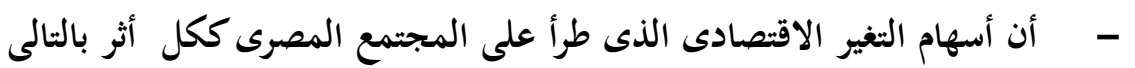

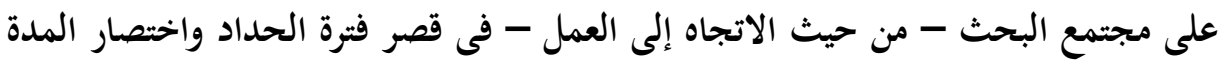

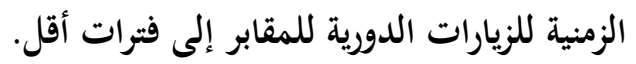

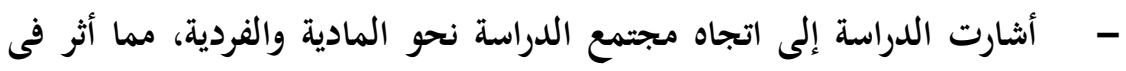
التخفف من دلائل الحزن وفترة الحداد. - - - أن التطور قد أسهم فى سير حركة القرية نحو التمدن.

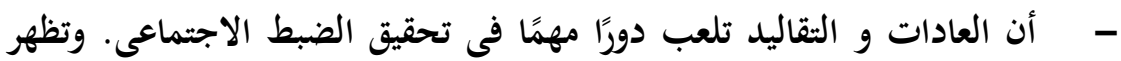
تلك العادات والطقوس التى تبدو فى إحدى مظاهرها فى التضامن الاجتماعى المتمثل فى إخراج صوانى الطعام، والاشتراك فى شعائر العزاء فى مجتمع الدراسة والخوف من النقد الاجتماعى إذا ماقصر الأفراد فى الوفاء بتلك الالتزامات. - - - تعكس عادات وتقاليد وشعائر الوفاة الكثير من العوامل الاقتصادية والرموز

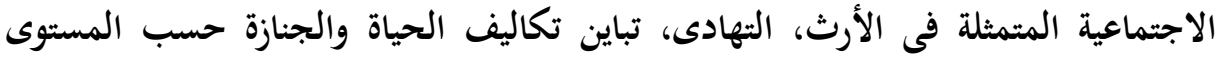
الاقتصادى للمتوفى. - - يوجد اعتقاد بأن القوى والشرور كالسحر والحسد تزداد فى فترات الانتقال من A حالة إلى حالة عند الميلاد والزواج والموت على نحو ما يقول "أدولف باخ". Bach - - مما تعكس شعائر وعادات وتقاليد الوفاة الكثير من الوسائل الوقائية والدفاعية. والمعتقدات الشعبية التى تستهدف حماية الأحياء من الأرواح. (وتظهر تلك الصفة المتأصلة

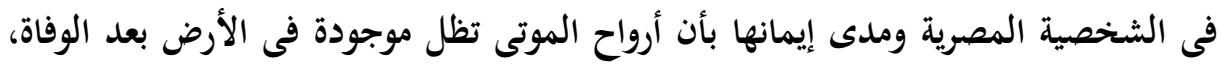




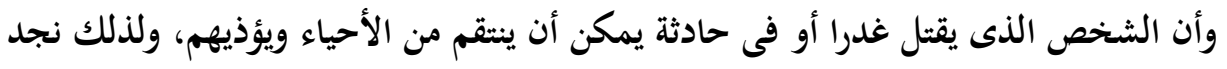

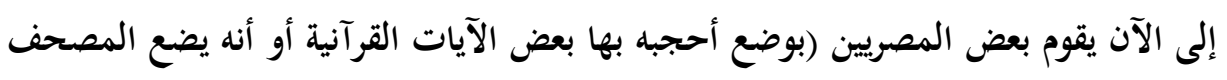
بجوار الرأس عند النوم، وقراءة المعوذات، وسورة الكرسى). 


$$
\text { المراجع }
$$

محمد الجوهري: علم الفولكلور- الأسس النظية والمنهجية، الجزء الأول،

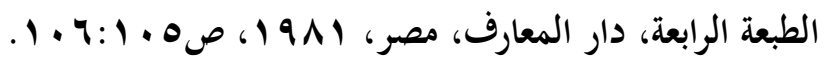

(2) Richard Huntington and Peter Metcalf, Celebrations of death (London, Cambridge University press, 1999.,25.

فاروق محمد العادلى: المجتمع القروى دراسة فى فكر ردفيلد من خحلال

منظور أنثربولوجى ثقافى فى بحوث الأنثربولوجيا العربية، تحرير ناهد صالح- مطبوعات مركز

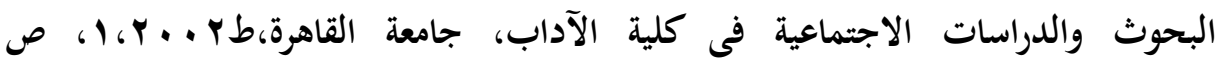

$$
\text { ص }
$$

شارلوت سيمور سميث، ت. محمد الجوهرى وآخرين: موسوعة علم الإنسان

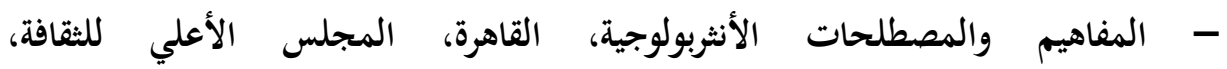

$$
\text { .0.. ص.1991 }
$$

(0) بول غليونى ت. زينب الدواجنى:الحضارة الطبية فى مصر القديمة، دار

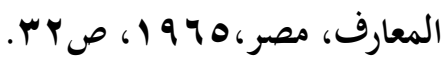

(") أمين سلامة (مترجم): الحياة اليومية عند قدماءالمصريين، القاهرة،الهيئة

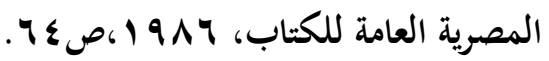

محمد الجوهري، وعبد الله الخريجي: طرق البحث الاجتماعي، دار الثقافة (V)

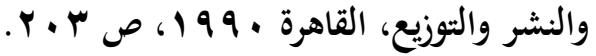

$$
\begin{aligned}
& \text { : مرجع سابق، ص } 101 \text { : }
\end{aligned}
$$

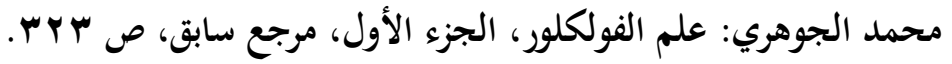

محمد الجوهرى وعبد الله الخريجى: مرجع سابق، ص مه r.

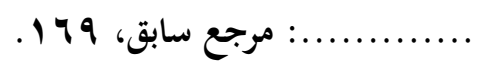

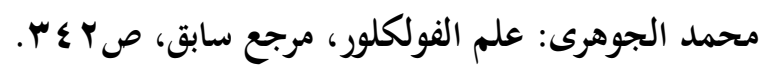

(13) Arnold Van Gennep:: The Rites 
(14) of Passage translated by: Monika B. Vizedam and Gabrielle L. Coffee. Routledge and Kegan Paul, London, 1960.P.P2,3

(15) Ibid,p.6

(7 (1) منى ابراهيم حامد الفرنواني: بعض ملامح التغير الاجتماعي والثقافي في الريف المصري كما تعكسه عادات دورة الحياة، دراسة متعمقة لقرية مصرية، رسالة دكتوراه، غير منشورة، جامعة عين شمس، كلية البنات، 1919.

(IV) سميح عبد الغفار شعلان: الموت فى المأثورات الشعبية،عين للدراسات

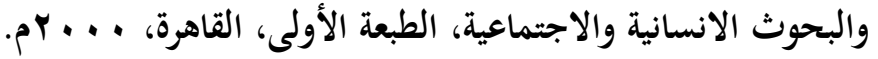

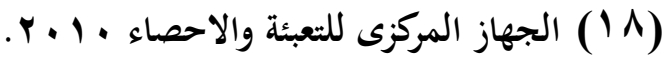

(9 (1) شمس الدين فرح الانصارى القرطبى: التذكرة فى أحوال الموتى وأمور الآخرة،

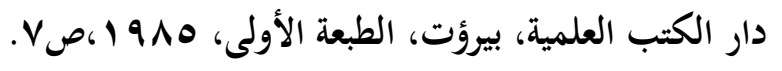

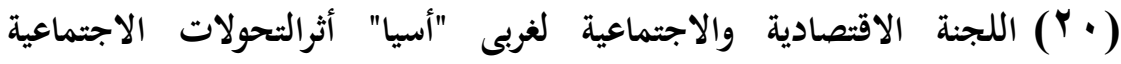

والاقتصادية على الأسرة العربية، دراسة استطلاعية" الأمم المنحدة، إبريلج9 9 (، الص ب.

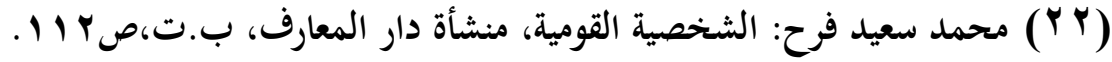

(YT) جامعة الاسكندرية: ابحاث اعادة بناء الانسان المصرى، التقرير الثالث. (Y)

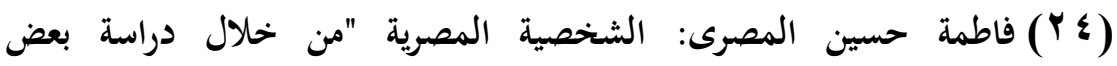
مظاهرالفولكلور المصرى" دراسة نفسية تحليلية أنثربولوجية، الهيئة المصرية العامة الئة

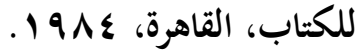

(Y0) نهلة إبراهيم: الأبعاد الاجتماعية والثقافية للشخصية القومية المصرية،الطبعة

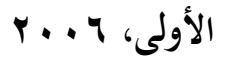

(†廿) أحمد زايد واعتماد علام: التغير الاجتماعى، الأنجلو المصرية، القاهرة،

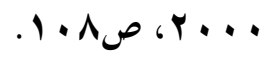




$$
\begin{aligned}
& \text { محمد عبده محجوب،فاروق أحمد مصطفى وآخرون:دراسات انثربولوجية فى (YV) }
\end{aligned}
$$

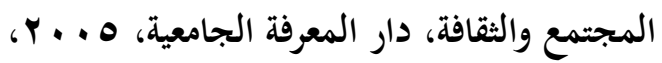

(28) Bronislow Malinowski, Argonauts of the Western Pacific. Dutton and Company,Inc., London,PP24,25 (29) Ellen baronet, the Appointed How Death, world View and Social change in Brittang(University of claifornia press,1989,pp.328-339

محمد الجوهري، عبد الحميد حواس، علياء شكري، الدراسة العلمية للعادات

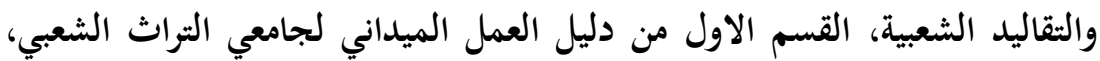

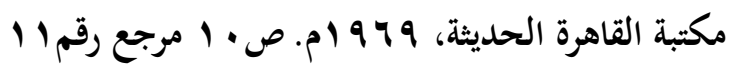

(31) (s): Stephanie CoontzSource; Journal of Marriage and Family, Vol. 66, No. 4 (Nov., 2004), pp. 974-979Published by: National Council on Relations.StableURL71.Accessed: . 14/05/2013 

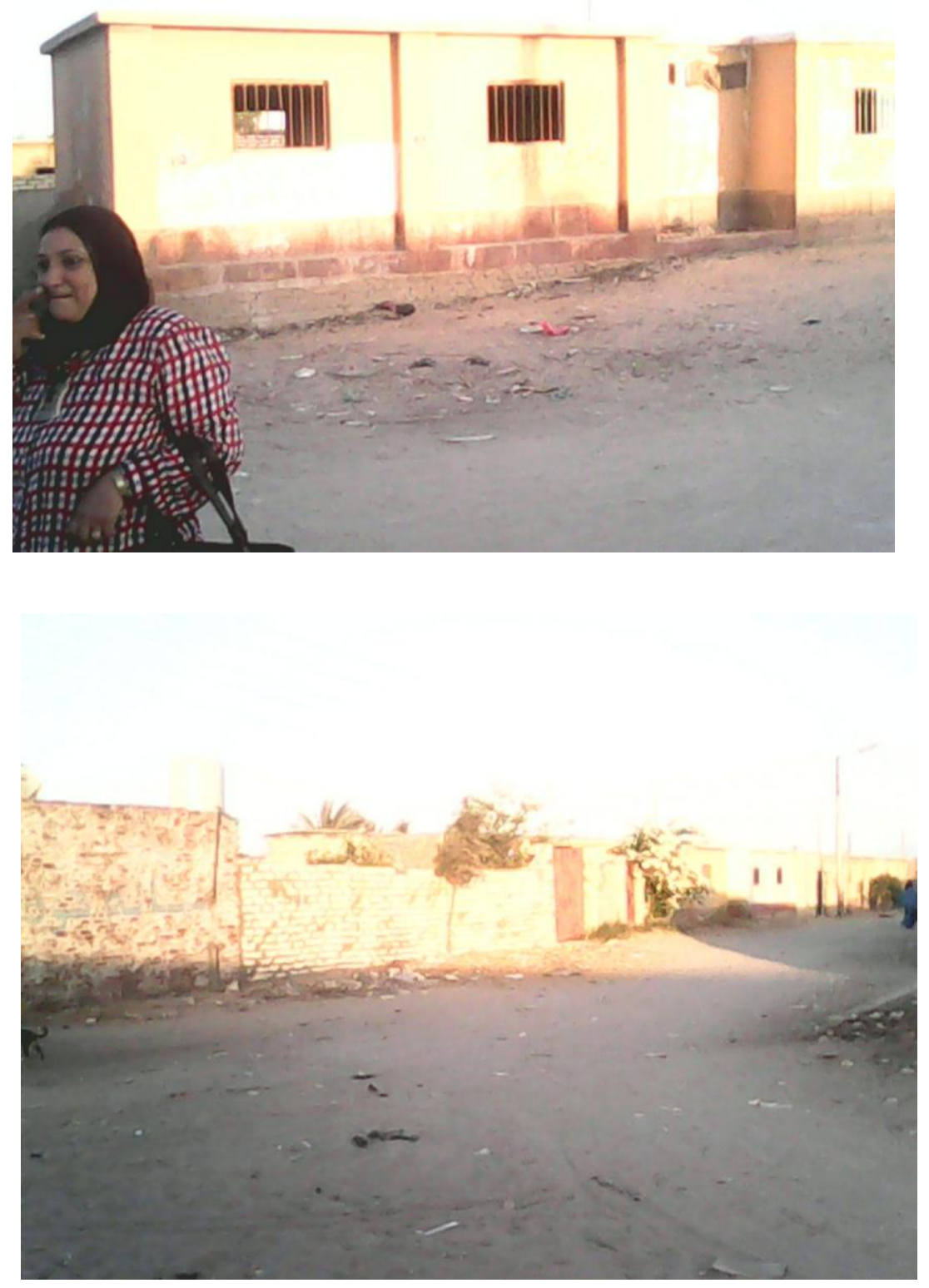

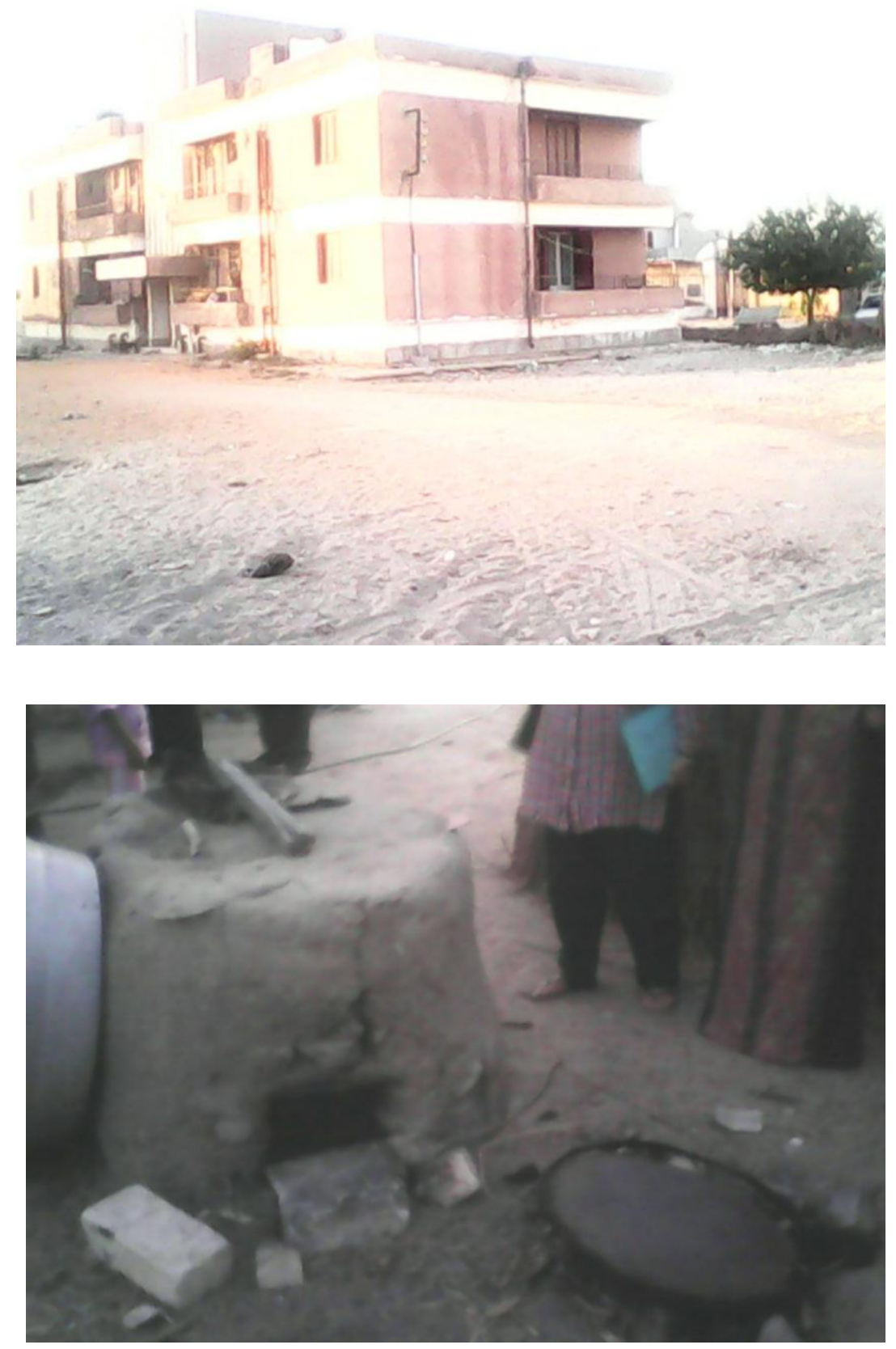

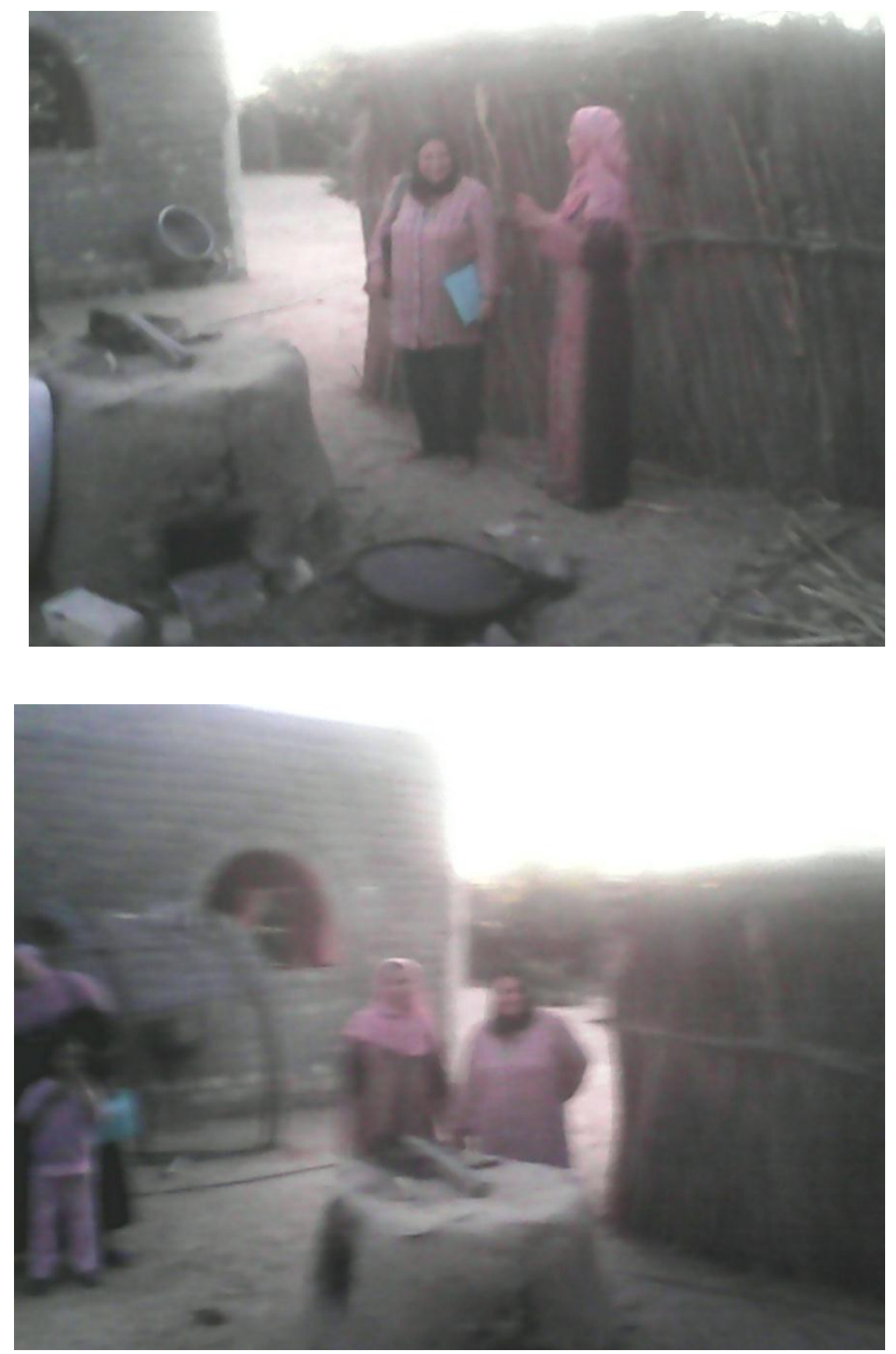

01 

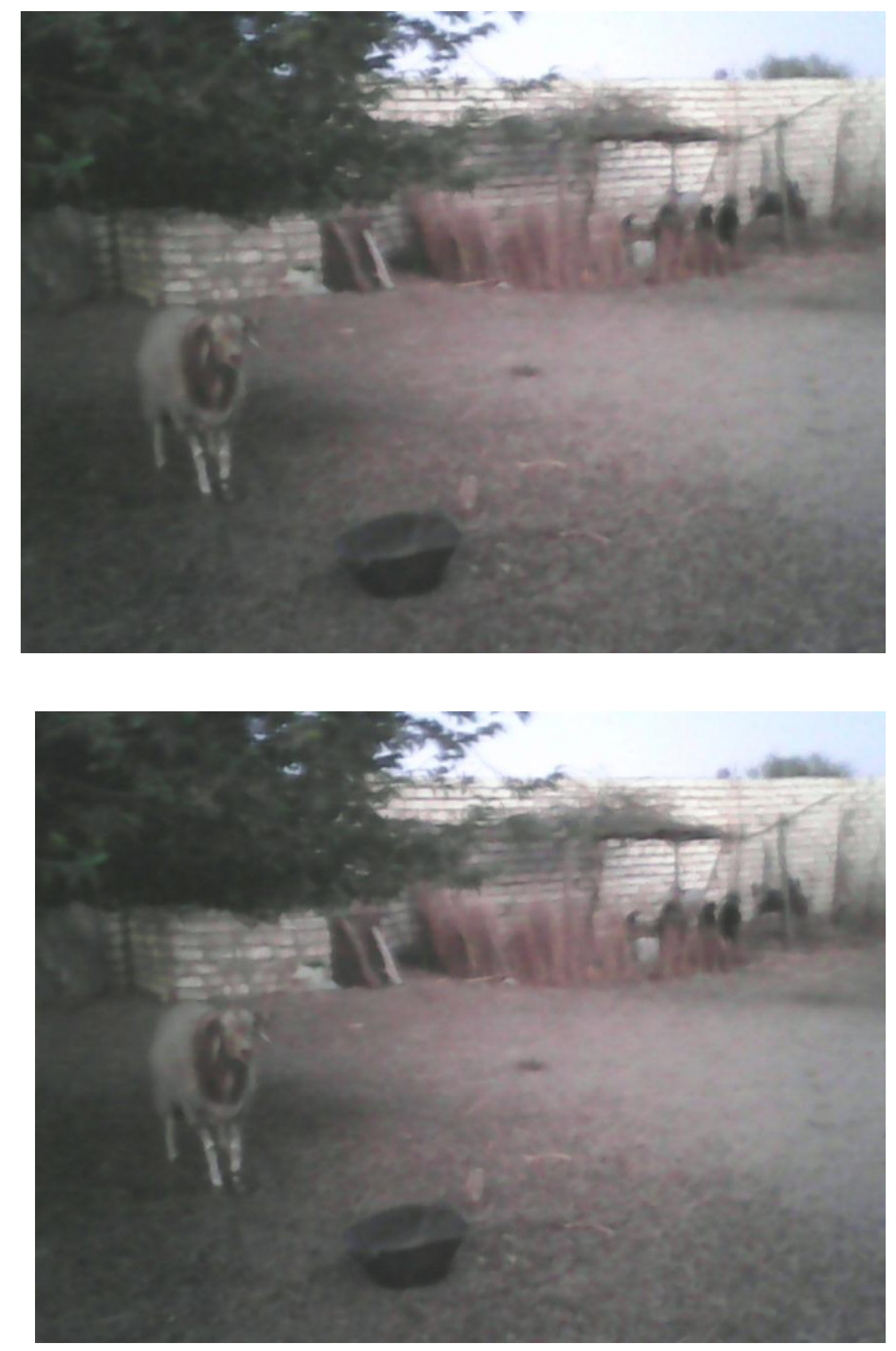


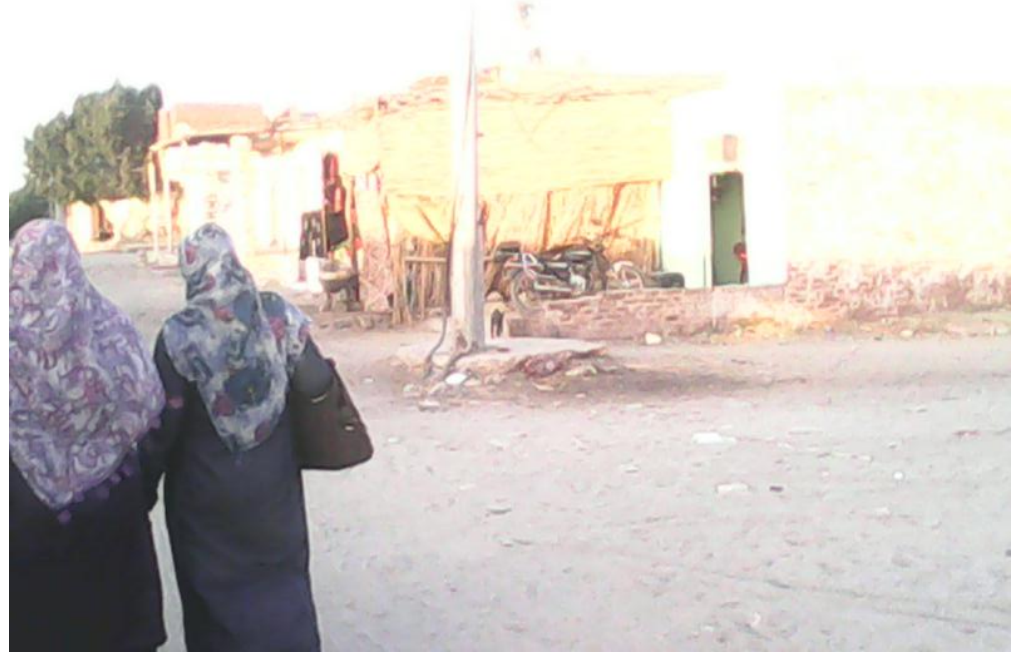

